\title{
ANALYSIS OF THE GAMMA SPECTRA OF THE URANIUM, ACTINIUM, AND THORIUM DECAY SERIES
}

by

\section{Michael H. Momeni}

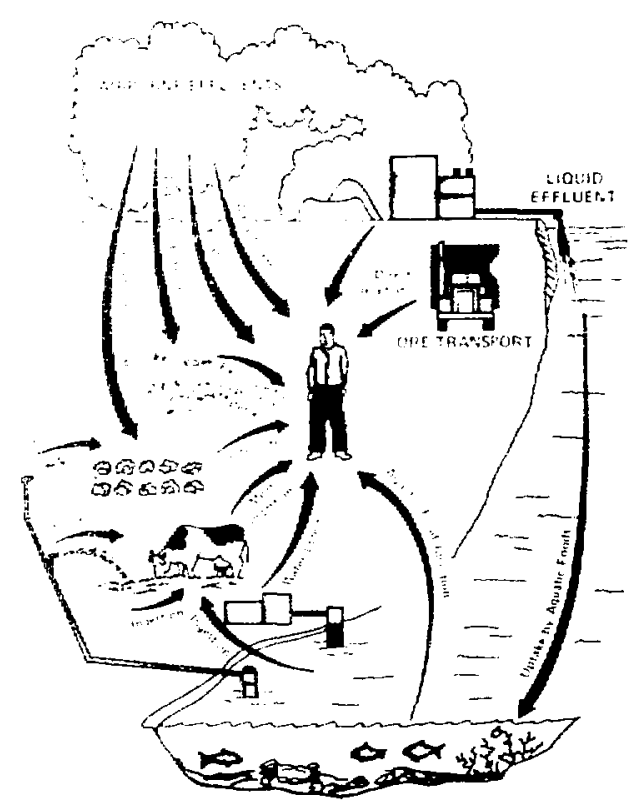

HUMAN-EXPOSURE PATHWAYS FROM

URANIUM-MINING AND -MILLING FACILITIES 
The facilities of Argonne National Laboratory are owned by the United States Government. Under the Ierms of a contract (W-31-109-Eng-38) among the U. S. Department of Energy, Argonne Universities Association and The University of Chicago. the University employs the staff and operates the Liaboratory in accordance with policies and programs formulated. approved and resiewed by the Association.

\section{MEMBERS OF ARGONNE LNIVERSITIIS ASSOCIATION}

The University of Arizona Carnegie-Mellon University Case Western Reserve University The University of Chicago University of Cincinnati Illinois Institute of Technology University of Illinois Indiana University The Universily of lowa Iowa State Universit?
The University of Kansas Kansas Stare I niversity losola Linisersity of Chicago Marquete Liniversity The Iniversits of Itichigan Michigan Stake L niversily L'niversity of Minnesotat Iniversity of Miswouri vorthuestern linisersity Lmersity of Volle Dame
The Ohio State Liniversity

Ohio Liniversity

The Pennslaania State University Purdue Eniversity Sain Loui Lnisersity Southern Illinois L'niversity The Lniversily of Texas at Aus:in Uashington Liniversity Wayne Sate L'nisersity The Lniversity of Wisconsm-Madison

This report was prepared as an account of nork sponsored by an agency of the L'nited States (iovernment. Neither the United States Government nor any agency thereof, nor any of their employees, makes any warranty, express or implied, or assumes any legal liability or responsibility for the accuracy, completeness, or usefulness of any information, apparatus, product, or process disclosed, or represents that its use uould not infringe privately owned rights. Reference herein to any specific commercial product, process, or service by trade name, trademark, manufacturer, or otheruise, does not necessarily constitute or imply its endorsement, recommendation, or favoring by the United States Government or any agency thereof. The views and opinions of authors expressed herein do not necessarily state or reflect those of the United States Government or any agency thereof.

Printed in the United States of America Available from

National Technical Information Service U.S. Department of Commerce 5285 Port Royal Road Springfield, VA 22161

NTIS price codes

Printed copy: A06

Microfiche copy: A01 
Distribution Category:

Enviromental Control Technology and Earth Sciences (UC-11)

ANL/ES-118

\section{ARGOLNE NATIONAL LABORATORY \\ 9700 South Cass Avenue \\ Argonne, Illinois 60439}

ANALYSIS OF THE GAMA SPECTRA OF THE URANIUM, ACTINIUM, AND THORIUM DECAY SERIES

by

Michael H. Momeni

Division of Envirommental Impact Studies

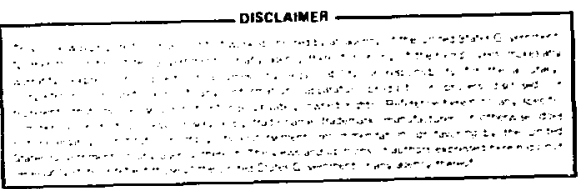

September 1981 


\section{FOREWORD}

This report is a sumary of a progran to develop an integrated gama-ray spectroscopy system for use in measurewent of concentrations of radionuclides in solid samples collected near active and inactive uranium mining, milling, and fuel-processing facilities. Use of high-resolution gama detectors allows specific quantification of the level of ground contanination. A gana spectra of a sample of uranium mill tailings may show more than 150 individual peaks between a 40 - to $1500-k e V$ energy band. This necessitated a neticulous calibration of the system for gama energy, efficiency, and precise knowledge of intrinsic radionuclide intensities.

This work was initially sponsored by the Division of Safeguards, Fuel Cycle and Environmental Research, U.S. Nuclear Regulatory Comission, and was completed under auspices of the U.S. Department of Energy in support of the Uranium Mill Tailings Remedial Action Program. 
CONTENTS

Page

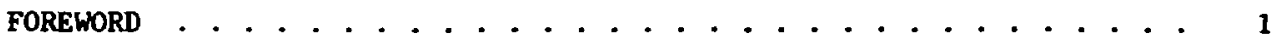

CONTENTS .............................. . . . . . . 5

FIGURES . . . . . . . . . . . . . . . . . . . 6

TABLES ............................ . . . . . . 7

ABSTRACT ............................ . . . . . 8

1. INTRODUCTION . . . . . . . . . . . . . . . . . . . 8

2. SPECTROMETER SYSTEM . . . . . . . . . . . . . . . . . . . 9

3. ANALYSIS OF GAMMA SPECTRA . . . . . . . . . . . . . . . . . . 15

3.1 Gamna Spectra . . . . . . . . . . . . . . . . . . . . . 15

3.2 Shape Functions . . . . . . . . . . . . . . . . . . . 19

3.3 Peak Search Routine ....................... 21

3.4 Deconvolution of a Gama Spectrun . . . . . . . . . . . . . 24

3.5 Determination of Radioactivity ................. 25

3.5.1 Isotope Identification . . . . . . . . . . . . . . . . 28

3.5.2 Detection Linit . . . . . . . . . . . . . . . . 29

3.6 Calibration . . . . . . . . . . . . . . . . . . 29

3.6.1 Energy Calibration . . . . . . . . . . . . . . . 29

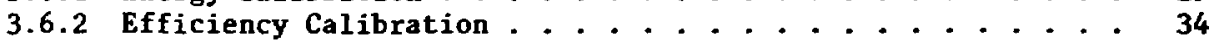

4. GAMA SPECTRA OF THE URANIUM, ACTINIUM, AND THORIUM

DECAY SERIES .......................... . . 36

4.1 Gamma Energies and Quantum Yields . . . . . . . . . . . . . 36

4.2 Conclusion . . . . . . . . . . . . . . . . . . 38

REFERENCES .......................... . . . 74

APPENDIX A. PREPARATION AND ANALYSIS OF STANDARDS . . . . . . . . . 77

APPENDIX B. POLYNOMIAL COEFFICIENTS FOR THE EFFICIENCY FUNCTION

AND STATISTICS OF LEAST-SQUARES FIT OF DATA . . . . . . . 99

ACKNOWLEDGHENTS . . . . . . . . . . . . . . . . . . . . 100

DISTRIBUTION IIST . . . . . . . . . . . . . . . . . . . 101 


\section{FIGURES}

Figure $\quad \underline{\text { Page }}$

1.1 Uranium-238 Decay Series ..................... 10

1.2 Thoriun Decay Series....................... 11

1.3 Actinium Decay Series . . . . . . . . . . . . . . . . . 12

2.1 Diagram of the Gama Spectroneter . . . . . . . . . . . . . 14

3.1 Gama Spectra of Natural Uranium Sample, 0-1400 keV . . . . . . 16

3.2 Gamma Spectra of Natural Thorium Sample, 0-1400 keV . . . . . . . 17

3.3 Gamma Spectra of Uranium and Thorium Ores, 40-70 keV . . . . . . . 18

3.4 Gamma Spectra of Uranium and Thorium Ores, 70-120 keV . . . . . . 18

3.5 Peak Shape Parameters for a Gaussian Peak Folded into a

Step Function and an Exponential Function, $r=\left(x-x_{j}\right) / \rho_{j} . . . . .22$

3.6 Flow Diagran of the Spectral Analysis Program .. . . . . . . 23

3.7 Decay of $238 \mathrm{U}$ to ${ }^{23} \mathrm{gth}$ and ${ }^{23} \mathrm{gPa}$. . . . . . . . . . . . . . . 26

3.8 Flow Diagram of the Program for Isotope Detection and

Calculation of Radioactivity . . . . . . . . . . . . . . . 30

3.9 Energy Calibration of Gamma Spectra, 0 - $200 \mathrm{keV}$. . . . . . . . . . 32

3.10 Calculated Energy Minus Observed Energy (residuals)
of Gamma Spectral Energy Calibration for Region 1. . . . . . . 33

3.11 Energy Calibration of Gamma Spectra, 200-1400 keV . . . . . . . . 33

3.12 Calculated Energy Minus Observed Energy (residuals) of Gamma Spectral Energy Calibration of Region 2 . . . . . . . . 34

3.13 Calculated Efficiency and Measured Efficiency as a Function of Photon Energy .. . . . . . . . . . . . . . . . . . 35

4.1 Gamma Spectra of the Uranium and Thoriun Ores, 40-70 keV . . . . . 69

4.2 Gamma Spectra of the Uranium and Thorium Ores, 70-120 keV . . . . 69

4.3 Gamma Spectra of the Uranium and Thoriun Ores, 120-200 keV . . . . 70

4.4 Gamna Spectra of the Uranium and Thorium Ores, 200-400 keV . . . . 70

4.5 Gama Spectra of the Uranium and Thorium Ores, 400-600 keV . . . . 71

4.6 Gamma Spectra of the Uranium and Thoriun Ores, $600-800 \mathrm{keV} . . .77$

4.7 Gamma Spectra of the Uranium and Thoriun Gres, 800-1000 keV . . . 72

4.8 Gamma Spectra of the Uranium and Thoriun Ores, 1000-1200 keV . . . 72

4.9 Gamma Spectra of the Uranium and Thoriun Ores, 1200-1400 keV . . . 73 


\section{TABLES}

Table Page

2.1 Average Background Count Rates at Selected Energies . . . . . . 15

3.1 Energy Calibration . . . . . . . . . . . . . . . . . 31

4.1 Detected Peaks in a Sample of Ore Containing Uraniu and
Actinium Series in Secular Radioactive Equilibrium . . . . . . 40

4.2 Detected Peaks in a Sample of Ore Containing Uranium, Actiniun, and Thoriu Series in Secular Radioactive Equilibrium ...................... . . 45

4.3 Energy and Quantua Yield of Selected Nuclides in the Uranium Series........................ 4 49

4.4 Energy and Quantun Yield of Selected Nuclides in the Actinium Series ...................... 51

4.5 Energy and Quantum Yield of Selected Nuclides in the Thoriun-232 Series... . . . . . . . . . . . . . . . 52

4.6 Energy and Quantum Yield of Nuclides in the Uranium Series: Comparison of Values Measured in This Study with Those Previous ly Reported ...................... 53

4.7 Energy and Quantu Yield of Nuclides in the Actiniu Series: Comparison of Values Measured in This Study with Those Previously Reported .. . . . . . . . . . . . . . . . . . 59

4.8 Energy and Quantuw Yield of Nuclides in the Thoriun Series: Comparison of Values Measured in This Study with Those Previously Reported ..................... 63 
ANALYSIS OF THE GAYMA SPECTRA OF THE URANIUM, ACTINIUM, AND THORIUM DECAY SERIES

by

Michael H. Momeni

\begin{abstract}
This report describes the identification of radionuclides in the uranium, actinium, and thorium series by analysis of gama spectra in the energy range of $40-1400 \mathrm{keV}$. Energies and absolute efficiencies for each gama line were measured by means of a highresolution gernanium detector and compared with those in the literature. A gama spectroscopy wethod, which utilizes an on-line computer for deconvolution of spectra, search and identification of each line, and estination of activity for each radionuclide, was used to analyze soil and uraniun tailings, and ore.
\end{abstract}

\title{
1. INTRODUCTION
}

Gamma-ray spectroscopy provides an inexpensive and efficient nethod for measuring the contamination of the environments of facilities processing natural, depleted, and enriched uranium. In general, radionuclide concentrations in environmental samples way be determined by means of radiocheaical separations, followed by alpha- and beta-ray spectroscopy. But these techniques, in comparison with high-resolution gama-ray spectroscopy, are laborious and time consuming, preventing an extensive sampling procedure often demanded by environmental prograns. In recent years, the application of on-line minicomputers to the analysis of complex gama-ray spectra has further 
facilitated and tailored the process of data reduction, error analysis, and search for radionuclides in the uranium, thoriun, and actiniu decay series.

Figures 1.1 through 1.3 depict the decay series of uranium $(\mathrm{U}-238)$, thorium (Th-232), and actiniun (U-235). The structures and emission characteristics of these series have been studied by Hyde, Perlanan and Seaborg (1964); Lederer, Hollander and Perlman (1968); Gunnink et al. (1969); Kogan et al. (1969); Adans and Gasparini (1970); Smith and Wollenberg (1972); Davidson and Conner (1968); Lingewan et al. (1969); Bjornholn et a1. (1968); and Godart and Gizon (1973). The most recent compilation of gama-ray spectra recorded by germanium detectors is that of Heath (1975). However, in many cases, the reported intensities do not agree, and the absolnte intensities are not available.

High-resolution gereaniun detectors are capable of recording more than 150 distinct peaks within the $40 \mathrm{keV}$ to $2 \mathrm{MeV}$ energy region. Deconvolution of gamma-ray spectra, identificatior of radiounclides from the gama lines, and calculation of the concentration of each radionuclide demand accurate knowledge of both gamma energies and the intensities of the gama transitions of each radionuclide. In this report, procedures for deconvolution of gama-ray spectra and radionuclide identification are described. Gama transition intensities and energies for the prominent peaks were measured and compared with those reported in the literature.

\section{SPECTROMETER SYSTEM}

The application of a gama spectrometer to measurements of environmental samples requires the following:

1. A resolution better than $2 \mathrm{keV}$ [full-width-half-naximun (FWHM)] at the 1.33 HeV peak of Co-60,

2. A lower detection limit of $40 \mathrm{keV}$ and a upper linit of $2 \mathrm{MeV}$,

3. Relative photopeak efficiency of more than $10 \%$,

4. Low background, 


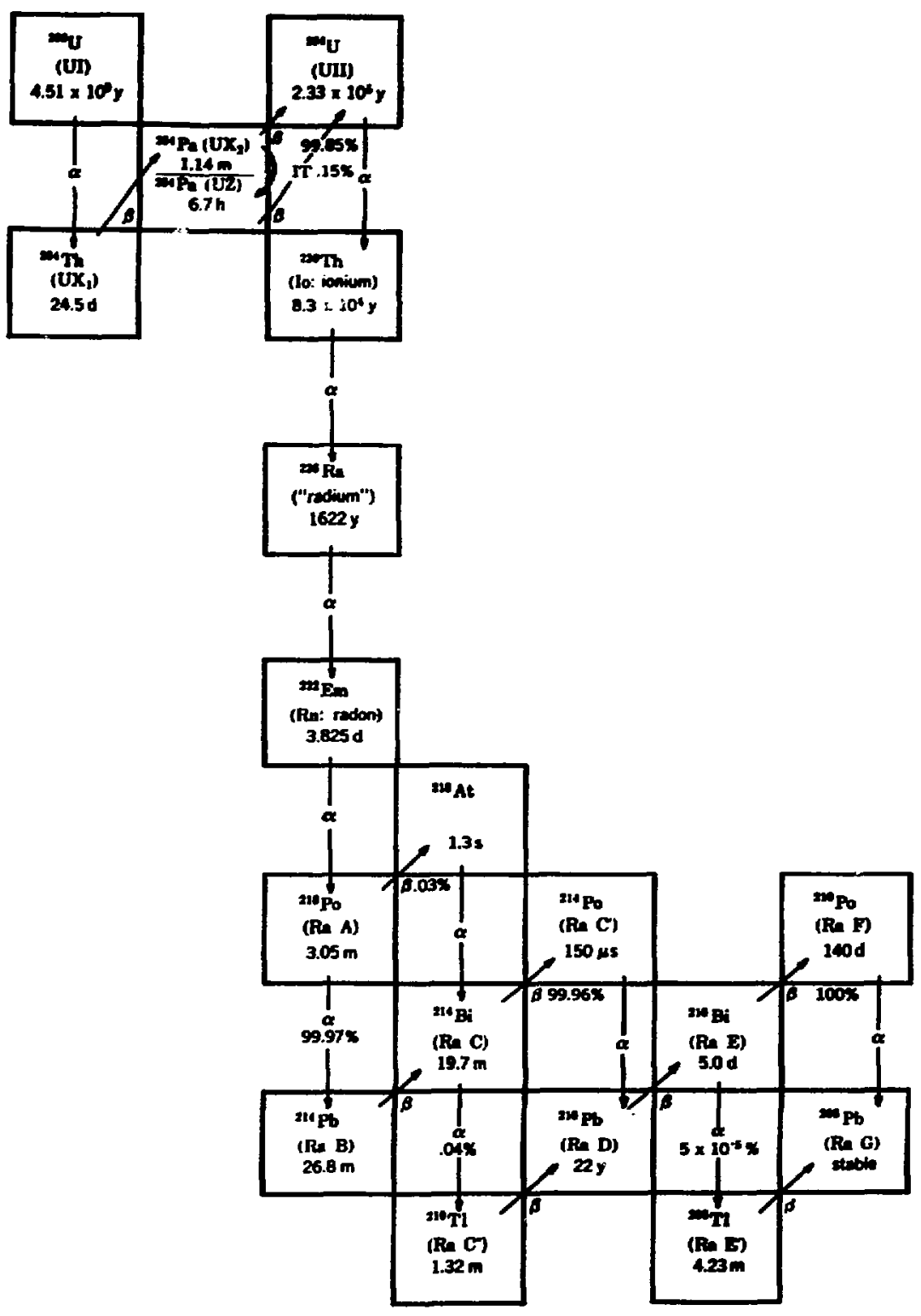

Figure 1.1. Urantum-238 Decay Sertes. 


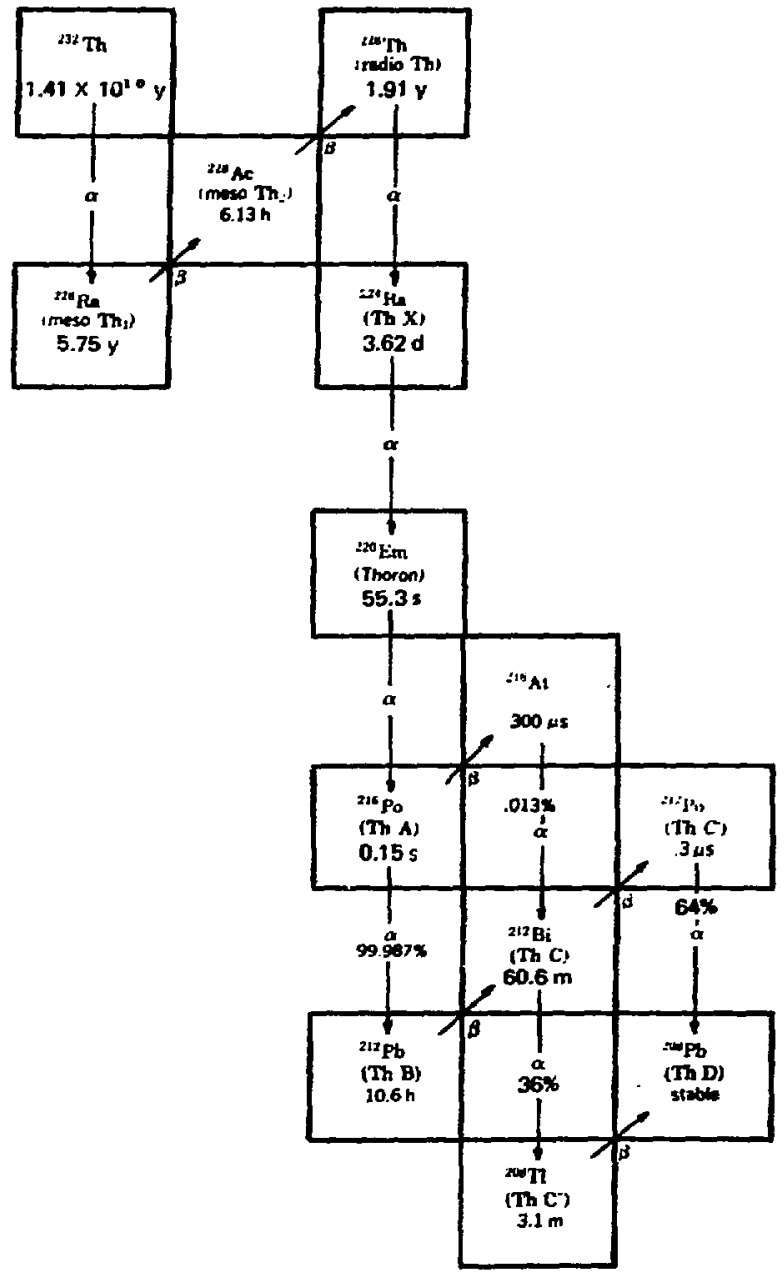

Figure 1.2. Thortum Decay Sertes. 


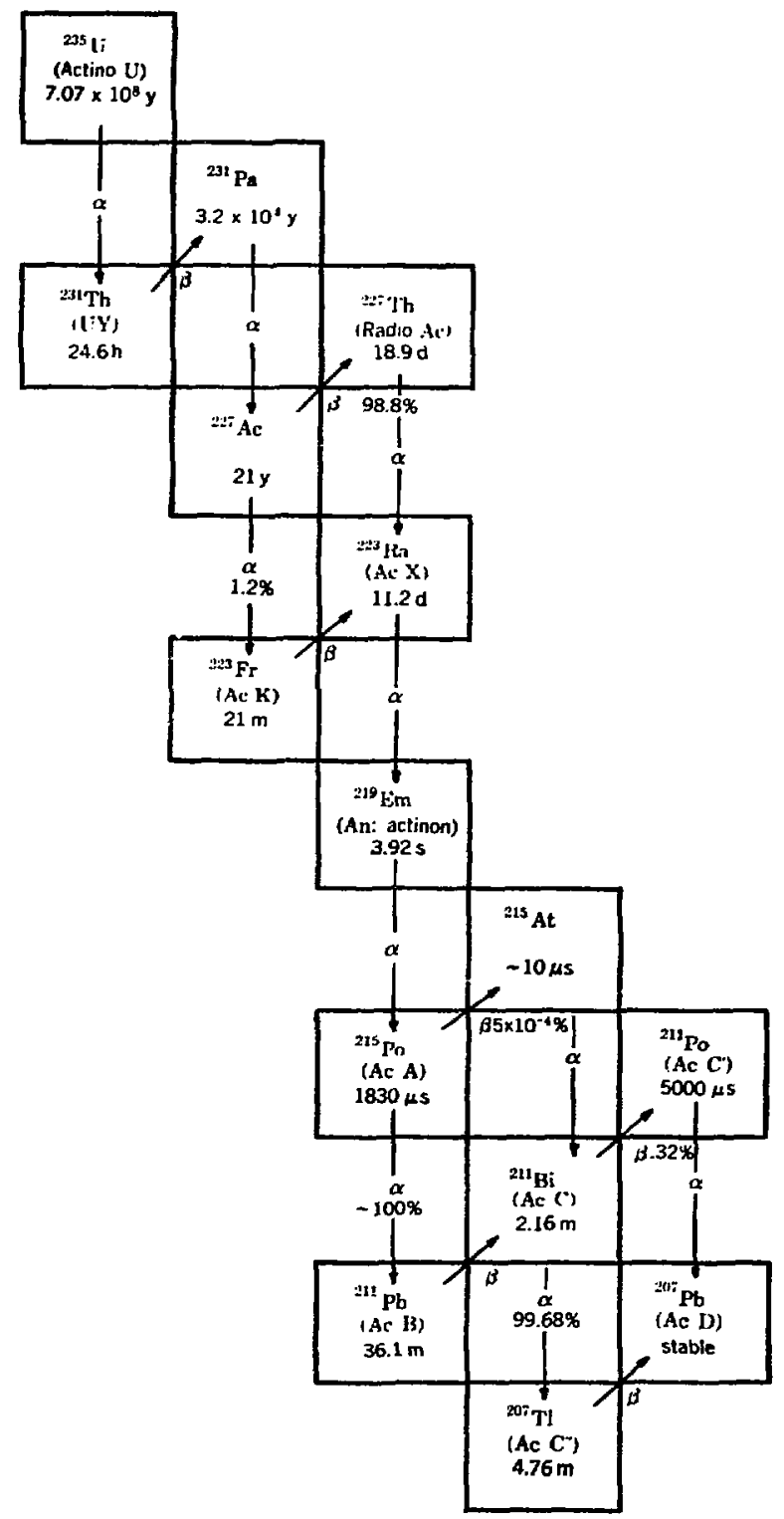

Figure 1.3. Actinium Decay Series. 
5. Stable electronics suitable for long-duration measurements of lowactivity samples,

6. A software package for deconvolution of complex gama spectra,

7. A procedure for identification of each gama line and assignment to a nuclide or nuclides, and

8. Calculation of activity for each of the radionuclides and the detection limit for each of the radionuclides that were not observed.

The spectrometer design is shown in Figure 2.1. The detector is an upward, true coaxial, lithium-drifted germanium detector (ORTEC) with a resolution of $1.8 \mathrm{keV}$ at the $1.33 \mathrm{MeV}$ photopeak of Co-60 with a peak to Compton ratio of 44:1. The detector and the cooled FET (ORTEC) preamplifier are housed in a $12-\mathrm{cm}$-thick steel shield that is about $100 \mathrm{~cm}$ above the ground. The following systems were utilized:

1. Analog-to-digital converter, Ino-Tech model $2105,50 \mathrm{MHz}$.

2. Spectroscopy amplifier, C:tec Model 472A.

3. Livetime corrector/pileup rejector, Canberra model 1468.

4. Dual random nuclear pulse generator, ANL.

5. Ino-Tech ultima II multichannel analyzer, model 3408 .

6. $32 k$ NOVA computer.

7. Tektronix systems 4014-1, 4054, and 4907 .

The zero channel and the gain were software controlled. Two energy-stable, random nuclear pulses were generated, one at the lowest energy channel (first 10 channels) and the other at the highest. These reference pulses $(10,000 \mathrm{cps})$ were stored in a buffer memory and were scanned once every 100 seconds. Subsequently, the most likely centroid channels for these reference pulses were calculated, and the zero channel and gain were computed by means of these centroids. The sample spectrum collected within the next 100 seconds was then adjusted for the channel location. Comparison of the centroids calculated over a period of time for a gamma line of known intensity, within an energy range of $40 \mathrm{keV}$ to $2 \mathrm{MeV}$, showed no evidence of drift in gain or degradation of peak resolution. Table 2.1 shows the background count rates at selected gamma energies measured for periods of 70 hours, as well as the estimated errors of deconvolution of the ganma spectra. 


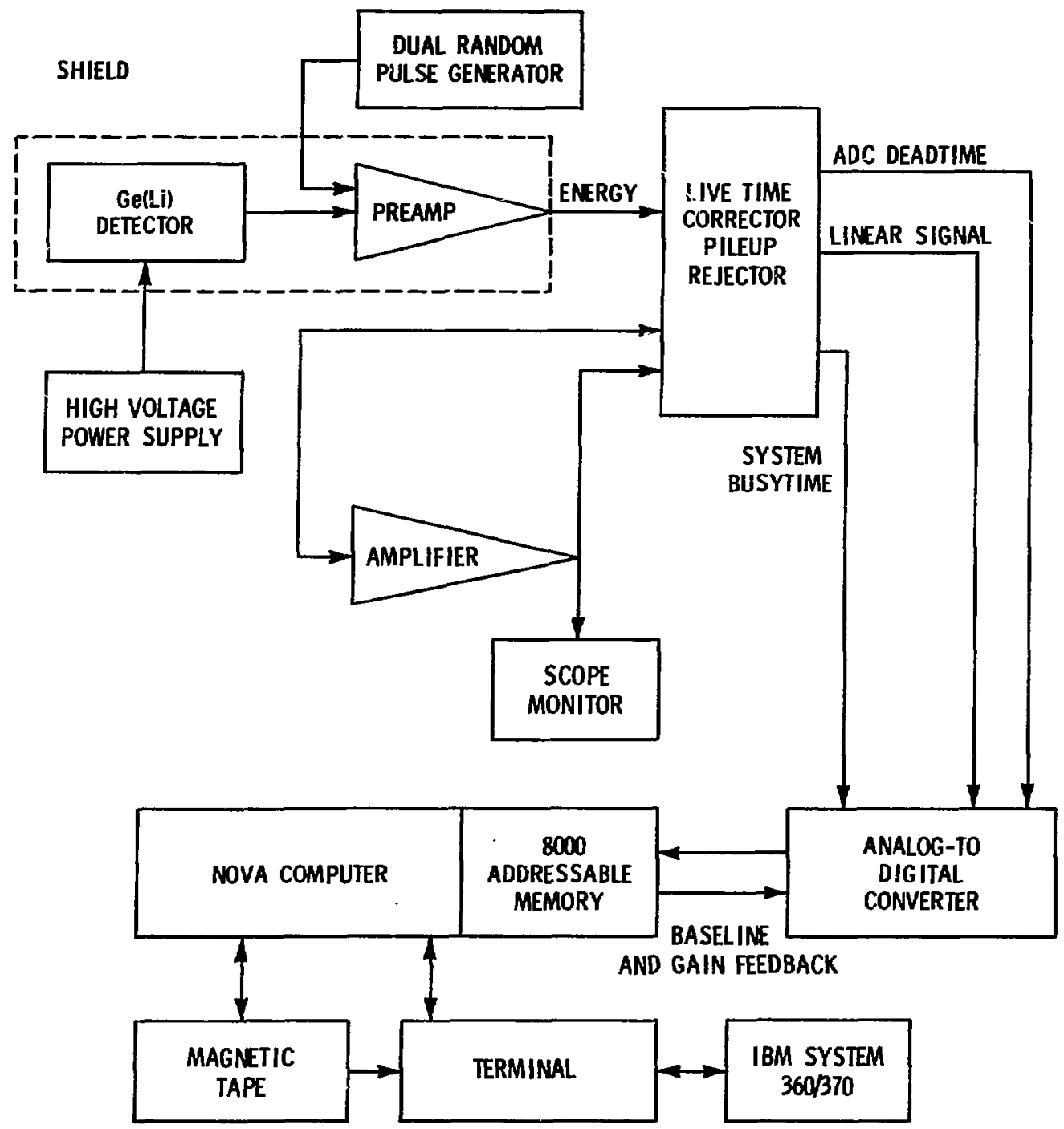

Figure 2.1. Diagram of the Gamma Spectroneter. 
Table 2.1. Average Background Count Rates at Selected Energies

\begin{tabular}{|c|c|c|c|c|}
\hline $\begin{array}{r}\text { Energy } \\
\text { (keV) }\end{array}$ & $\begin{array}{l}\text { Area } \\
\text { (counts) }\end{array}$ & $\begin{array}{c}\text { Error } \\
(\chi) \text { Area }\end{array}$ & $\begin{array}{c}\text { Count Rate } \\
(\mathrm{cpm})\end{array}$ & Radionuclide \\
\hline $\begin{array}{r}46.5 \\
63.3 \\
92.8 \\
185.7 \\
238.6 \\
351.8 \\
510.7 \\
609.4 \\
727.3 \\
911.1 \\
988.1 \\
1238.2\end{array}$ & $\begin{array}{r}250 \\
468 \\
1395 \\
997 \\
1368 \\
670 \\
5692 \\
378 \\
100 \\
306 \\
179 \\
52\end{array}$ & $\begin{array}{r}28.90 \\
31.20 \\
8.85 \\
11.85 \\
7.50 \\
14.25 \\
7.95 \\
11.95 \\
34.0 \\
12.25 \\
13.90 \\
26.0\end{array}$ & $\begin{array}{l}5.95 \mathrm{E}-2 \\
1.11 \mathrm{E}-1 \\
3.32 \mathrm{E}-1 \\
2.37 \mathrm{E}-1 \\
3.26 \mathrm{E}-1 \\
1.60 \mathrm{E}-1 \\
1.36 \mathrm{E} 0 \\
9.06 \mathrm{E}-2 \\
2.38 \mathrm{E}-2 \\
7.29 \mathrm{E}-2 \\
4.26 \mathrm{E}-2 \\
1.24 \mathrm{E}-2\end{array}$ & $\begin{array}{c}\mathrm{Pb}-210 \\
\mathrm{Th}-234 \\
\mathrm{Th}-234 \\
\mathrm{U}-235 / \mathrm{Ra}-226 \\
\mathrm{~Pb}-212 \\
\mathrm{Bi}-211 / \mathrm{Pb}-214 \\
\mathrm{~T} 1-208 \\
\mathrm{Bi}-214 \\
\mathrm{Bi}-212 / \mathrm{Ac}-228 \\
\mathrm{Ac}-228 \\
\mathrm{Ac}-228 \\
\mathrm{Bi}-214\end{array}$ \\
\hline
\end{tabular}

\section{ANALYSIS OF GAMMA SPECTRA}

\subsection{Gamma Spectra}

The gamma spectra of natural uranium and thorium samples in the 40- to $1400-\mathrm{keV}$ range are shown in Figures. 3.1 and 3.2. Stripping the spectra for calculation of the area under each peak, e.g., at $46.5 \mathrm{keV}$ of Pb-210 (Fig. 3.3), requires correction for the contribution of the adjacent peaks and the continuum. The shape of each observed peak is not truly Gaussian; it rises sharply on the high energy side and skews on the low energy side (response function). The ideal distribution of a gamma-ray with a negligible natural energy width is Gaussian, but because of equipment noise, incomplete charge collection, pileup, and scape of annihilation radiation, the distribution at the low-energy side is exponential. Thus, a discontinuity appears in the background continuum above and below the initial gana photopeak. Moreover, on occasion, neighboring peaks will overlap, precluding any simple hand calculation or electronic integration of the area above the continum, e.g., the regions between $70-80 \mathrm{keV}$ (Fig. 3.4). 


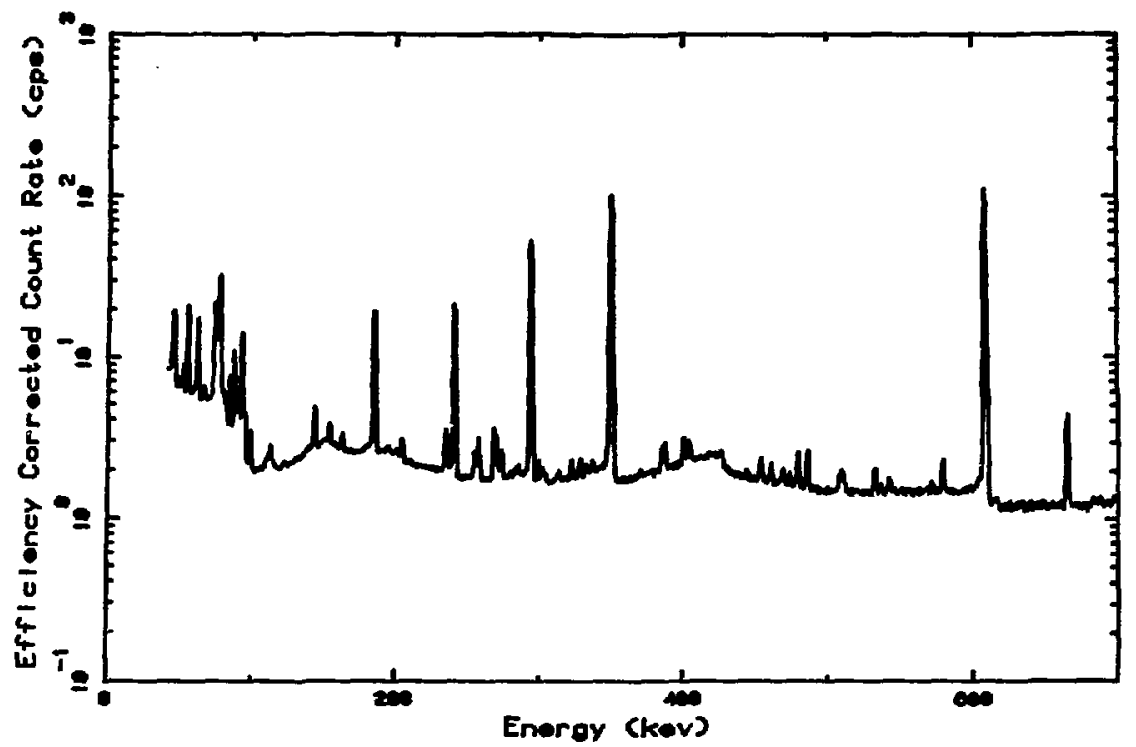

(a)

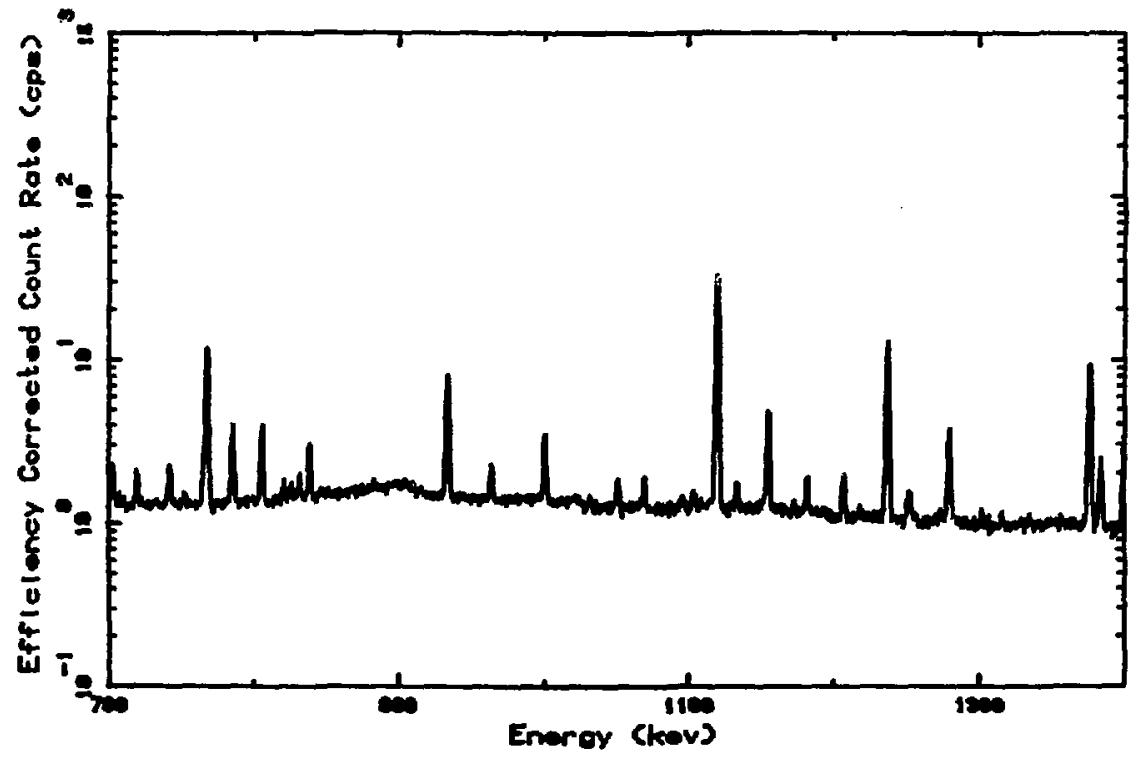

(b)

Figure 3.1. Gana Spectra of Natural Uraniun Saple, 0 - $1400 \mathrm{keV}$. 

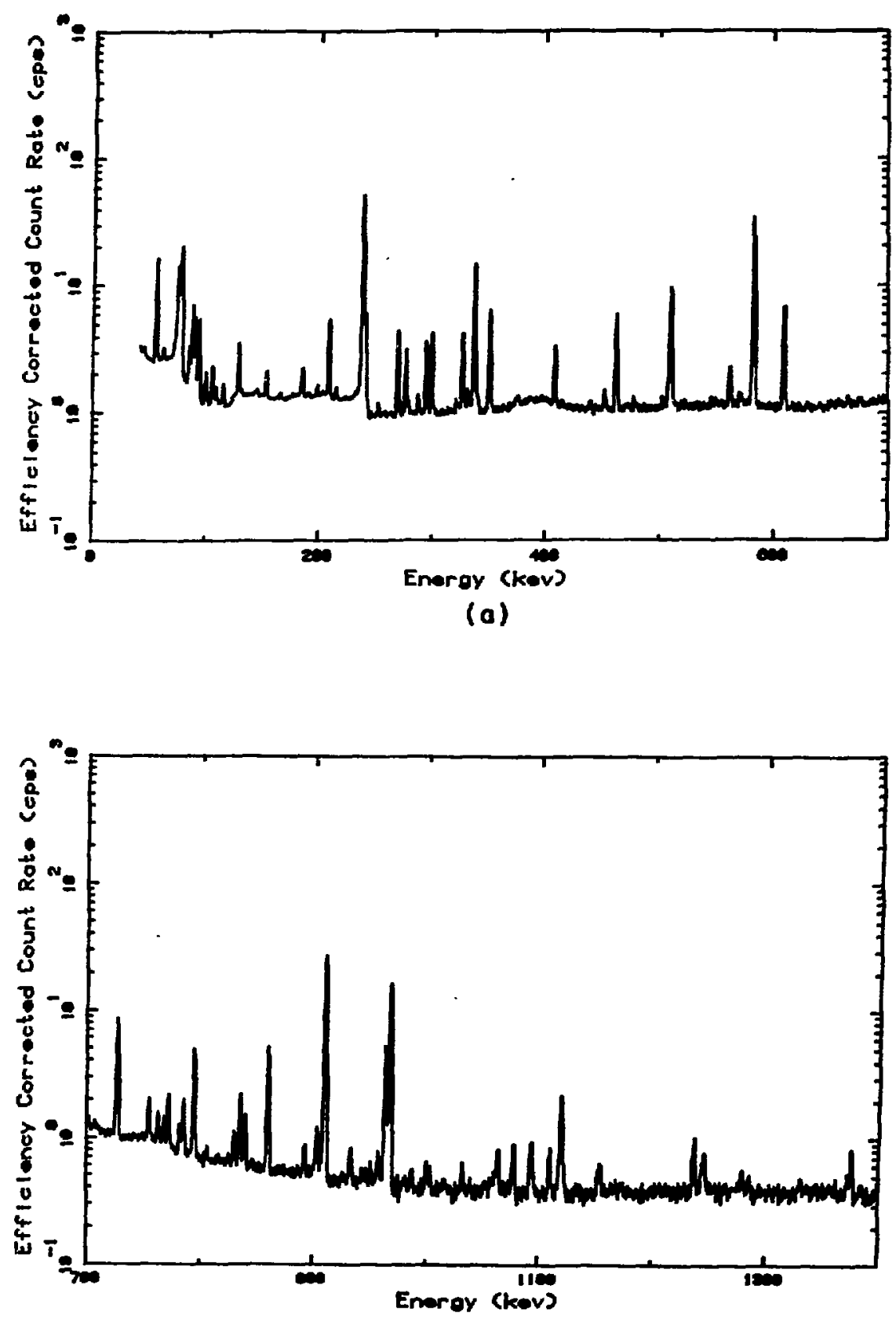

(b)

Figure 3.2. Gamma Spectra of Natural Thorium Sample, 0 - $1400 \mathrm{keV}$. 


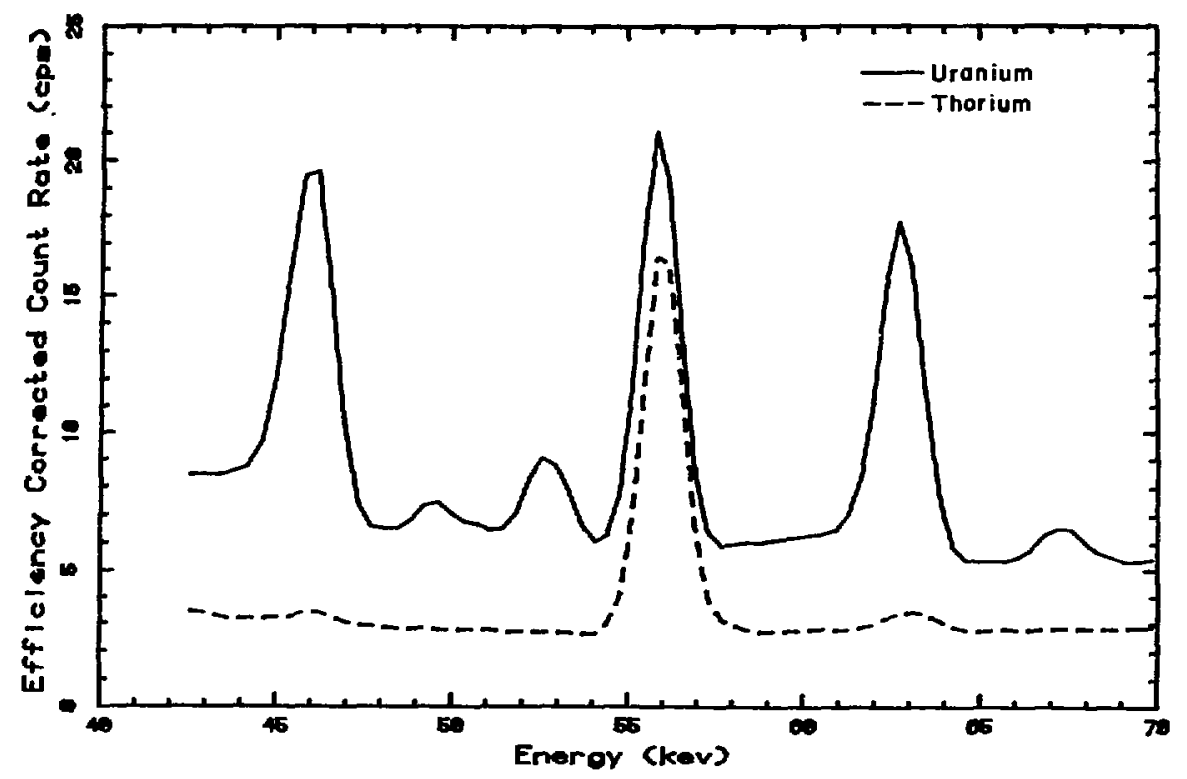

Figure 3.3. Gamma Spectra of Uranium and Thorium Ores, $40-70 \mathrm{keV}$.

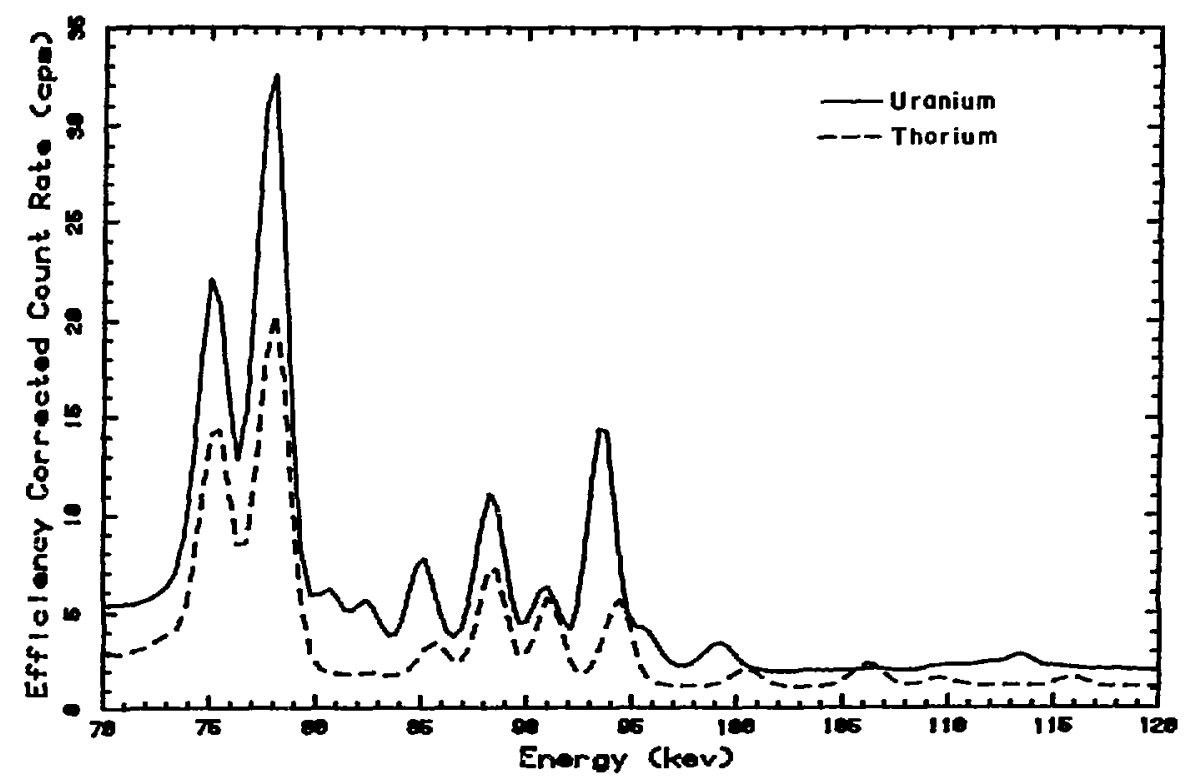

Figure 3.4. Gamma Spectra of Uranium and Thorium Ores, $70-120 \mathrm{keV}$. 


\subsection{Shape Functions}

Data collected in $\mathrm{N}$ channels of an analyzer take the form of a histogram of a continuous energy spectrum within a range of minimum $\left(E_{0}\right)$ and maximum $\left(E_{m}\right)$ energy. Under the condition of a linear energy-to-channel relationship, each channel will have an energy width of $\delta E=\left(E_{m}-E_{o}\right) / N$. A complex spectrum, as shown in Figure 3.1, consists of a linear superposition of contributions from each peak $j$, with energy $E_{j}$ and intensity $a_{j}$. The number of counts. i.e., the number of photons detected with an energy $E$, within the range of $E \pm I / 2 \delta E$, is given by

$$
n_{i}=\sum_{j=1}^{k} n_{i j}
$$

where $n_{i j}$ is the contribution of a peak $j$ to counts in channel $i$. The summation extends over the entire gamma spectrum, even though, on occasion, the upper energy $E_{k}$ could exceed $E_{m}$.

The intensity of a gamma line $j$ is proportional to the area $a_{j}=$ $\sum_{i=1}^{n} n_{i j}$ under the response function. The objective of a deconvolution pro-
cedure is to strip the spectrum into the components, i.e., peaks, and to calculate $n_{i j}$. The response function may be approximated by a shape function $f(x)$, where $x$ is a continuous variable analogous to the discrete index $i$ and a channel width $\delta x=K \delta E$, where $K$ is the slope of the energy channel function $\left(\mathrm{dE} / \mathrm{dx}=\mathrm{K}^{-1}\right)$. The area under peak $\mathrm{j}$ is calculated from

$$
a_{j}=\int_{x \min }^{x^{\max }} f_{j}(x) d x
$$


An individual peak, $a_{j}$, is superimposed on a continuum, which, within the region of integration, may be represented by a polynomial

$$
f_{c}(x)=A_{0}+A_{1}\left(x-x_{j}\right)+A_{2}\left(x-x_{j}\right)^{2}
$$

where $x_{j}$ is the centroid to the peak $j$, the region of interest, and $A_{j}$ is the amplitude of peak $j$. The shape function $f_{p}(x)$ for each peak $j$ is a Gaussian function $f_{g}(x)$, where

$$
f_{g}(x)=A_{j} \exp -\left[\frac{\left(x-x_{j}\right)}{\rho_{j}}\right]^{2},
$$

folded into an exponential function. The parameters of function $f_{g}(x)$ are as follows:

$A_{j}=$ the peak amplitude.

$\mathrm{x}=$ the channel location.

$x_{j}=$ the centroid for peak $j$ of energy $E_{j}$.

$\rho_{j}=$ the peak width (FWHM) $/ 2$.

The addition of an exponential function to the low-energy side of peak $j$ and the change of the $\log$ base from " $e$ " to " 2 " in the above equation results in

$$
f_{p}(x)=A_{j} 2^{\left[-\left(x-x_{j}\right)^{2} / \rho^{2}\right]},
$$

when

$$
\begin{aligned}
& -\alpha \leq\left[\left(x-x_{j}\right) / \rho_{j}\right] \leq \beta ; \\
& f_{p}(x)=A_{j} 2^{\left[\alpha^{2}+2 \alpha\left(x-x_{j}\right) / \rho_{j}\right]},
\end{aligned}
$$

when

$$
\left[\left(x-x_{j}\right) / \rho_{j}\right]<-\alpha ;
$$


and

$$
f_{p}(x)=A_{j} 2^{\left[\beta^{2}-2 \beta\left(x-x_{j}\right) / \rho_{j}\right]},
$$

when

$$
\left(x-x_{j}\right)>\beta ;
$$

where $\alpha$ is the skewing parameter for joining the Gaussizn to the exponential function, and $\beta$ is the upper energy cutoff channel. In addition, a step function, $f_{s}(x)$, is also included in the low-energy side of the peak (Fig. 3.5). The step function $f_{s}(x)$ for a relative step height $\delta$ is expressed as

$$
f_{s}(x)=A_{j} \delta\left\{2^{-\left[1.75\left(x-x_{j}\right) / \rho_{j}\right]}\right\}
$$

when

$$
\left(x-x_{j}\right) / \rho_{j} \geq 0
$$

and as

$$
f_{s}(x)=A_{j} \delta\left\{2-2^{\left[1.75\left(x-x_{j}\right) / \rho_{j}\right]}\right\},
$$

when

$$
\left(x-x_{j}\right) / \rho_{j}<0
$$

The computer program for this analysis was written for use on a NOVA computer. Figure 3.6 shows the program flow diagram.

\subsection{Peak Search Routine}

The initial procedures in deconvolution of a spectrum are separation of the true peak from statistical fluctuations and estimation of the contribution 


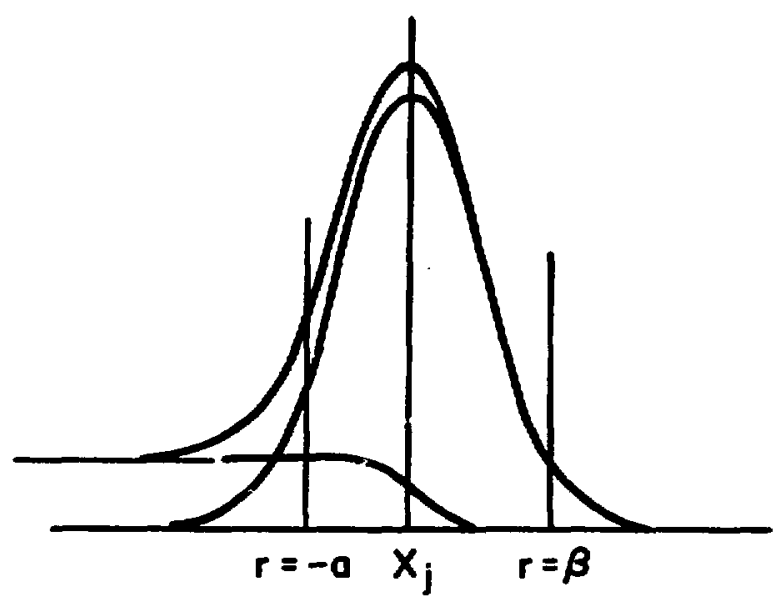

Figure 3.5. Peak Shape Parameters for a Gaussian Peak Folded into a Step Function and an Exponential Function, $r=\left(x-x_{j}\right) / \rho_{j}$.

to the continuum from other background features such as the Compton edge. In this program, the high frequency noise and the low frequency background are filtered by means of a square-wave correlator convolution function with a zero area (Philips and Marlow 1976). In the absence of a peak, the expected value of the correlator signal through the data is zero. In the presence of a peak, the expected value of the correlator signal in a channel " $i$ " exceeds a preselected number (search sensitivity value) of standard deviations of the measured count in that channel. The choice of a square-wave correlator with a width of about the same magnitude as the true width of the peaks effectively eliminates detection of statistical fluctuations as true peaks. Detailed discussions of the parameters affecting the deconvolution process and of data reduction are given by Fletcher and Powell (1963); Davidson (1965); Kearn (1969); Brown and Dennis (1970); Beeck (1975); McNelles and Campbell (1975); Brassard and Correias (1977); and Momeni (1978). 


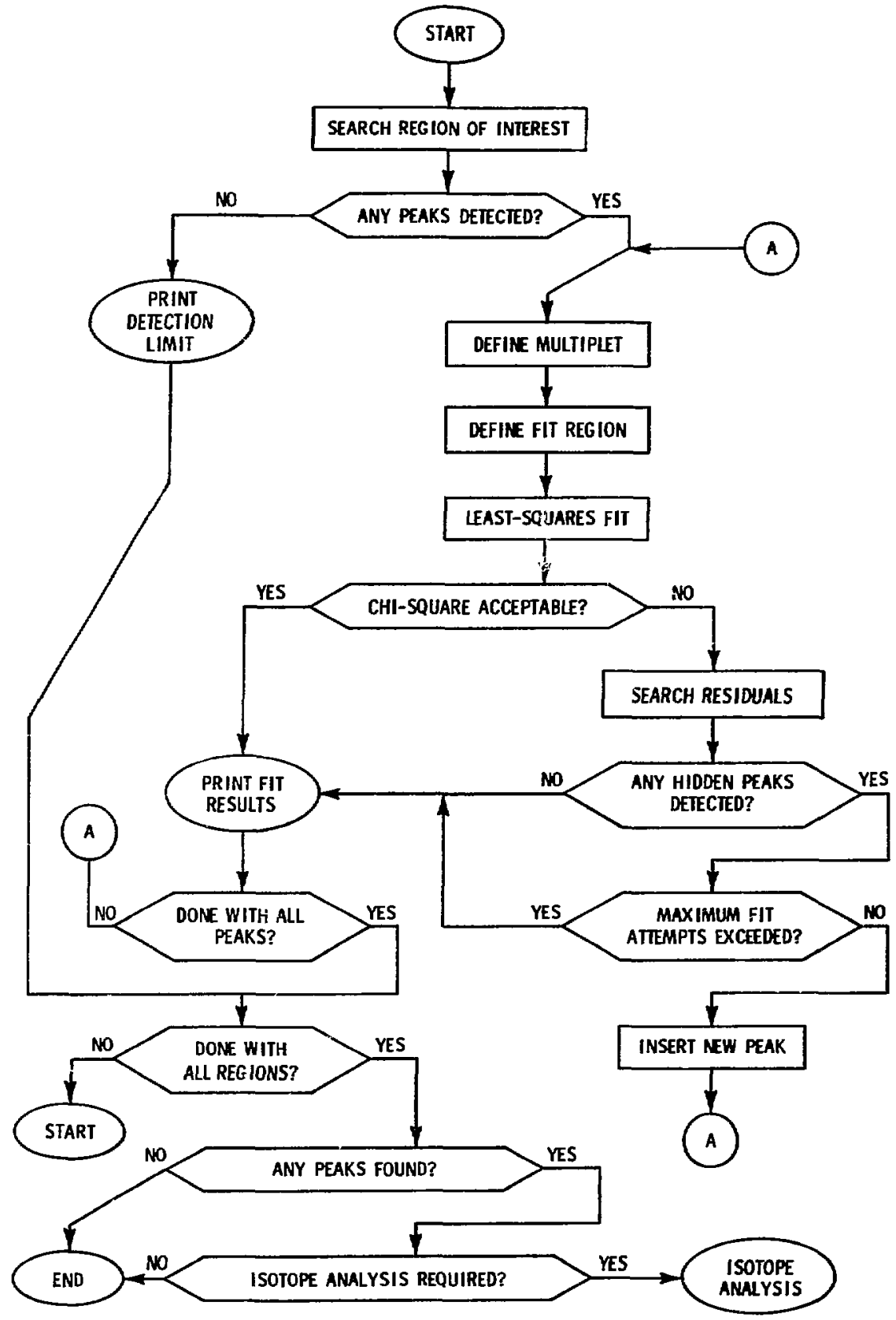

Figure 3.6. Flow Diagram of the Spectral Analysis Program. 


\subsection{Deconvolution of a Gama Spectrum}

To deconvolute a spectrum into individual peaks $j$ with area $a_{j}$ (intensity), the spectrum is divided into multiplets of regions. A maximum of 6 peaks is allowed in each subregion during each step of deconvolution. Peak shape functions and background functions are fitted into the individual peaks within each of the multiplets. If a satisfactory chi-square $\left(x^{2}\right)$ is not achieved, the residuals are searched for hidden peaks (Fig. 3.6). Then, the hidden peak is added to the multiplet and the data are reanalyzed. If the addition of the new peak to the multiplet exceeds the maximum number of peaks allowed in each multiplet, the subregion is further divided before reanalysis. In cases where the residuals do not indicate a hidden peak or where addition of the hidden peak degrades the $x^{2}$, the peak width is allowed to vary independently.

The procedure of fitting the functions to the data is a non-linear, least-squares, variable-metric minimization method (Garbow 1969, Davidson 1965, and Fletcher 1970). The procedure is accomplished by minimizing the least-squares deviation chi $(j)$ of the data $i_{j}$ from the shape function $f\left(x, q_{k}\right)$, by varying the fitting parameters $q_{k}$ of the shape function. The $x^{2}$ is given by

$$
\chi^{2}\left(q_{k}\right)=\frac{1}{n_{f}} \sum_{j}(\operatorname{chi}(j))^{2},
$$

for $n_{f}$ degrees of freedom. The function

$$
F\left(q_{k}\right)=\frac{1}{2} x^{2}\left(q_{k}\right)
$$

is optimized by an iterative search for the minimum in the function

$$
G\left(q_{\hat{k}_{k}}, i\right)=\frac{\partial F\left(q_{k}\right)}{\partial q_{k}} .
$$


In the neighborhood of the minimum value of $F\left(q_{k}\right)$, the inverse Hessian matrix of the function $F$ is approximately equal to the variance-covariance matrix (Phillips and Marlow 1976)

$$
\left.H \simeq|| \frac{\partial^{2} F\left(q_{i k}\right)}{\partial q_{i} \partial q_{k}}\right|^{-1} \mid
$$

The variance in the parameter $q_{i}$ is given by the diagonal elements of the matrix $H$, and the covariances of $q_{i}$ and $q_{j}$ are given by the off-diagonal elements. The value of matrix $H$ is systematically estimated by the variablemetric method (Davidson 1965, Fletcher 1970). The iteration procedure is repeated until either a satisfactory $\chi^{2}$ is obtained, no improvement in $\chi^{2}$ is achieved, or the maximum number of iterations is attained.

The net area $a_{j}$, for each peak $j$, is given by

$$
a_{j}=\sum_{i} f_{i j}\left(q_{k}\right)
$$

where $f_{i j}\left(q_{k}\right)$ is the shape function for the $j$ th peak at the $i$ th channel. The sum extends from 8 FWHM on the low-energy side to 4 FWHM on the high-energy side of the peak centroid. The error for each peak, $\sigma_{j}$, is computed from

$$
\sigma_{j}{ }^{2}=\sum_{i k}\left(\frac{\partial a_{k}}{\partial q_{i}}\right)\left(\frac{\partial a_{k}}{\partial q_{k}}\right) H_{i k}
$$

\subsection{Determination of Radioactivity}

Figure 3.7 depicts the transitions from $238 \mathrm{U}$ to $234 \mathrm{Th}$ and $234 \mathrm{~Pa}$. About $0.23 \%$ of the alpha decay transitions of $238 \mathrm{~g}$ to ${ }^{23} 9 \mathrm{Th}$ go to the $160 \mathrm{keV}$ excited state, about $23 \%$ go to the $50 \mathrm{keV}$ metastable state, and about $77 \%$ go to the ground state. De-excitation from the $50-\mathrm{keV}$ level to the ground state results in emission of $50-\mathrm{keV}$ gamma radiation. ${ }^{23} \mathrm{~g} \mathrm{Th}$ decays to ${ }^{23} \mathrm{~g} \mathrm{~Pa}$ by $\beta$ emission. About $72 \%$ of the beta transitions from the ground state of ${ }^{234} \mathrm{~Pa}$ to the excited 


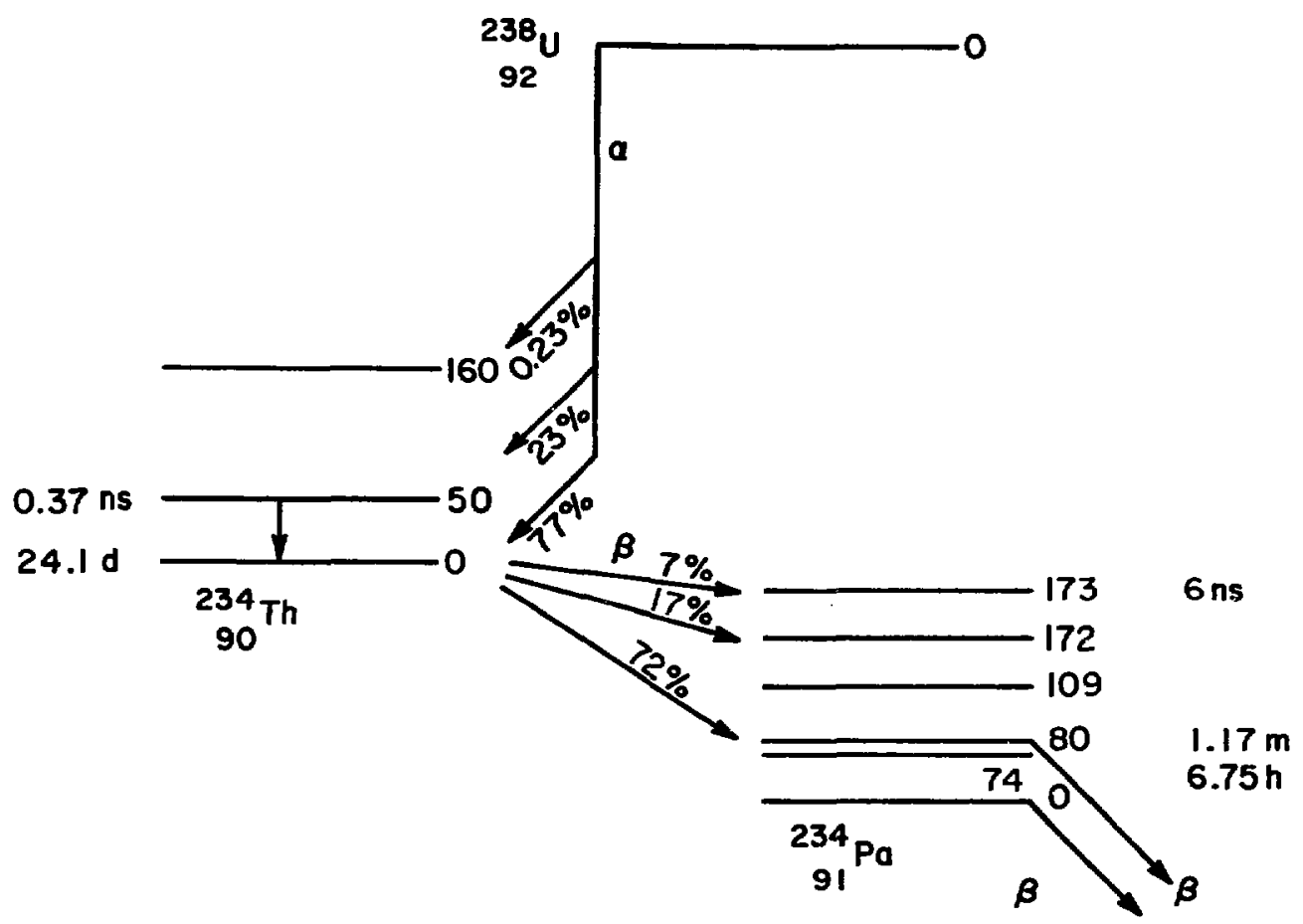

Figure 3.7. Decay of $238 \mathrm{U}$ to ${ }^{234} \mathrm{Th}$ and ${ }^{234} \mathrm{~Pa}$.

state of $\mathrm{Pa}-234 \mathrm{go}$ to the 1.17-minute metastable state of $\sim 80 \mathrm{keV}$, $17 \%$ to the $172.9-\mathrm{keV}$ level; and $7 \%$ to the $173.3-\mathrm{keV}$ level. Only $0.13 \%$ of the transitions from the 1.17 minute metastable state to the gro:ınd state of ${ }^{234} \mathrm{~Pa}$ are internal; the remainder are $\beta$ decays to the U-234 nuclide. De-excitation from the excited states of ${ }^{234} \mathrm{~Pa}$ to the ground state occurs by gamma emission. Transitions of the other nuclides in the uranium, actinium, and thorium series are reported by Lederer, Hollander and Perlman (1968) and in recent revision in (1978).

Gamma emissions from the decay of any of the nuclides in any of the series exhibit a set of discrete lines that can be used for the identification 
of the nuclide. Associated with each set of gamm lines is a set of intensities corresponding to the areas of the peaks $a_{j}$. The number, $N$, of decays of a radionuclide $p$ from a sample with an activity $A_{p}$ (in pCi) is

$$
N_{p}=2.22 A_{p}
$$

Of these transitions, a fraction $b_{p j}$ are photons with energy $E_{j}$ given by

$$
\mathrm{N}_{\mathrm{pj}}=\mathrm{b}_{\mathrm{pj}} \mathrm{N}_{\mathrm{p}}
$$

Thus, corresponding to a set of photons with energies $E_{j}$ are intensities $b_{p j}$, which are detected at the peak locations $j$. The fraction of the photons with the energy $E_{j}$ detected at $j$ is dependent on the detector size, sample configuration, detection geometry and the sample matrix. This fraction, $n$, is a function of energy and is given by

$$
n_{p j}=\varepsilon_{j} N_{p j},
$$

where $\varepsilon_{j}$ is the total detection efficiency of the gamma spectrometer system. Therefore, the activity $A_{p j}$ (in $p C i$ ) is calculated from

$$
A_{p j}=\frac{n_{p j}}{2.22 b_{p j} \varepsilon_{j}}
$$

The average activity $\left\langle A_{p}\right\rangle$, estimated from all ganma lines emitted by the radionuclide $p$, is given by

$$
\left\langle A_{p}\right\rangle=\frac{\sum_{j}^{\Sigma W_{j} A_{p j}}}{\sum_{p j}},
$$


where the sumnation is over all gamma lines emitted during transition of a radionuclide $p$ to its immediate daughter. The weight factor $W_{p j}$ is given by

$$
W_{p j}=\left(\frac{1}{\sigma_{a_{p j}}}\right)^{2}=\left(\frac{\varepsilon_{j} b_{p j}}{\sigma_{a_{p j}}}\right)^{2},
$$

where $\sigma_{F_{j}}$ is the exror from the estimation of the area of peak $j$. The statistical error associated with the average activity is the standard propagated statistical error:

$$
\sigma_{<A_{p}}^{2}>=\frac{\sum W_{p j}^{2} \sigma_{a_{p j}}^{2}}{\left(\Sigma W_{p j}\right)^{2}}
$$

In addition, the chi-square error from the deconvolution procedures is estimated from the minimum variance error by

$$
\sigma_{\text {chi-square }}^{2}=\frac{\sum W_{p j}\left(a_{p j}-\left\langle A_{p}\right\rangle\right)^{2}}{(N-1) \sum W_{p j}}
$$

under the condition that when $N=1, \sigma^{2}$ chi-square $=0$, where $N$ is the number of counts.

\subsubsection{Isotope Identification}

A set of gamma lines $j$ with distinct intensities $b_{p j}$ unambiguously identifies the presence of isotope $p$. The intensity of these lines can vary significantly from very faint to intense. Detection of the faint lines requires long acquisition time and occasionally may be unsuccessful during the peak search analysis. For example, a sample with an activity of 1 pCi of an isotope $p$ and $a$ photon intensity of $b_{p j}=1 \times 10-2$ emits only $2.22 \times 10-2$ photons/min. At a detection efficiency of $15 \%$, only $3.33 \times 10^{-3}$ gammas of energy $E_{j}$ are detected each minute, or 4.8 each day. This count rate is significantly smaller than the statistical fluctuation in the spectrometer background. Thus, for a sample with such low activity, the gamma line will not be 
perceptible. Therefore, the procedure for identification of an isotope on the basis of presence of all lines can fail even though the major lines are present. In our study, the procedure for identification of an isotope is based on the presence of the major lines, which are selected on the basis of their relative intensities. Figure 3.8 depicts the flow diagram of the program for isotope detection and activity calculation. Nuclides are identified by comparing the subset of the gamma lines (major lines) detected in the spectrum with those in the isotope library.

\subsubsection{Detection Limit}

The analysis of a sample often entails the calculation of the lowest detectable activity as an upper bound estimate of the concentration of a radionuclide not detected during the measurement. The algorithm for this calculation is based on the minimum peak detection correlator signal at the most prominent photon peak of the isotope. The net perk area $a_{d}$ associated with this line is computed for a peak with a mean correlator signal that is two standard deviations above the minimum detection signal and that assumes a Gaussian shape with a width (FWHM) adopted from the calibration procedure. Therefore, the minimum detectable activity is calculated fron

$$
A_{p}=a_{d} /\left(2.22 \varepsilon_{j} b_{p j}\right)
$$

\subsection{Calibration}

\subsubsection{Energy Calibration}

The purpose of energy calibration is to determine the functional relationship between energy and channel number. The initial step is determination of channel number and energy of a set of precisely known gamma lines. The preparation and anaylses of the standards are described in Appendix $A$. The standards used for energy and efficiency calibration were the following:

a. Radium (Ra-226) in secular radioactive equilibrium (National Bureau of Standards reference material 4959-130) with an uncertainty of $1.2 \%$ in the specified activity. 


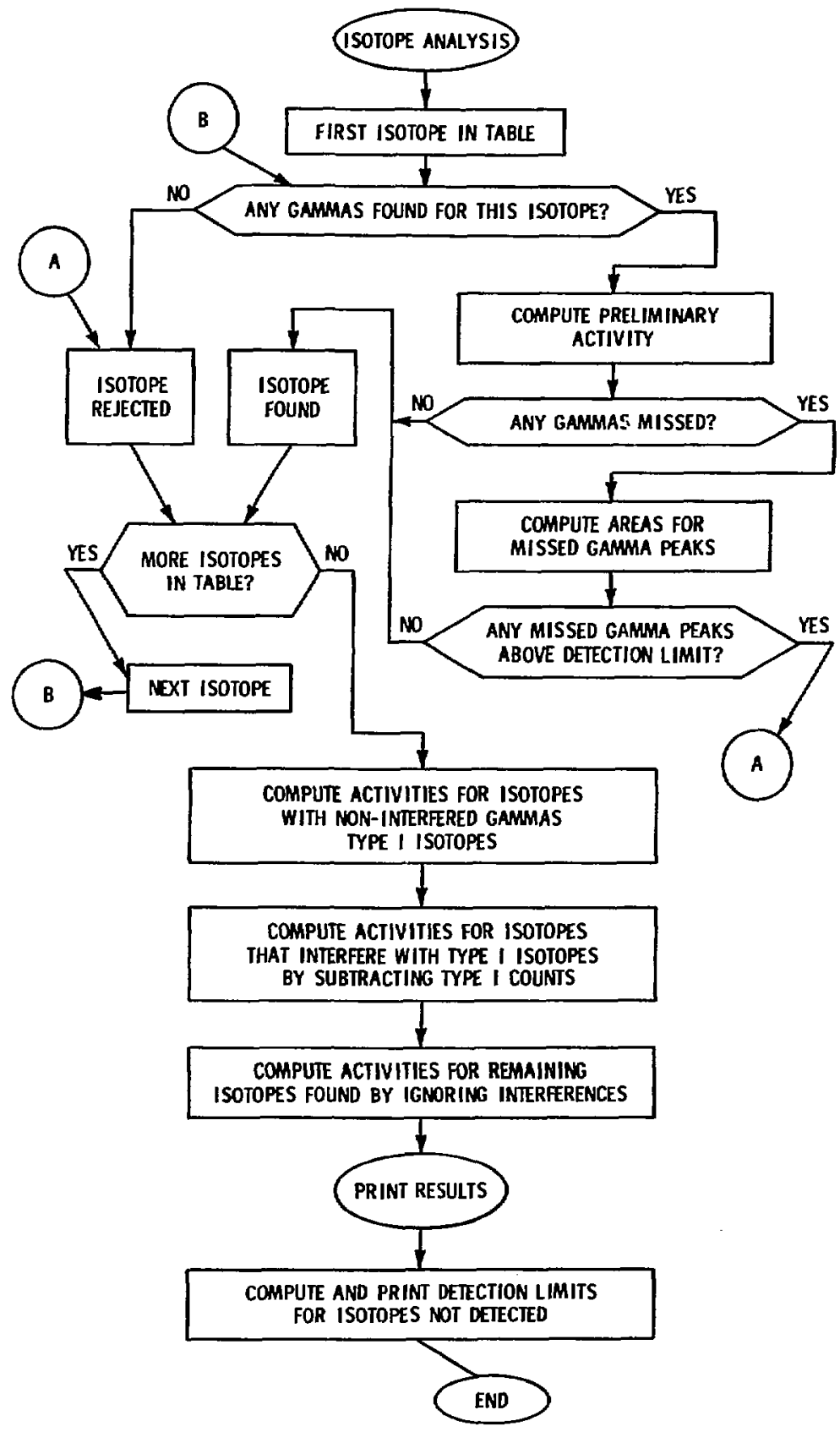

Figure 3.8. Flow Diagram of the Program for Isotope Detecton and Calculation of Radioactivity. 
b. Mixed radionuclide, gamma-ray emission-rate solution (standard reference material 4243G) containing the following radionuclides (uncertainties in specified activity in parentheses): Cd-109 (3.1\%), Co-37 (2.7\%), Ce-139 (1.3\%), $\mathrm{Hg}-203$ (2.3\%), Sn-113 (3.1\%), Sr-85 (2.5\%), Cs-137 (2.3\%), Y-88 $(3.1 \%), \mathrm{Y}-88(2.5 \%)$, and $\mathrm{Co}-60(1.6 \%)$.

c. Thorium ore $(1.01 \pm 0.01 \%$ ) at a $95 \%$ confidence level, plus $0.04 \%$ uranium from New Brunswick Laboratory, Sample No. 79 (monozite sand, $\mathrm{Th}=8.44 \%$, in dunite).

d. Pitchblende ore $\left(53.55 \% \mathrm{U}_{3} \mathrm{O}_{8}\right)$, Sample No. 6, New Brunswick Laboratory.

e. Additional gamma standards for energy were $\mathrm{Am}-241, \mathrm{~Pb}-210$, and $\mathrm{Se}-75$.

For a functional representation, the spectrum was subdivided into two regions, channels 1-400 and channels 401-4000. Then for each region, a polynomial function was fitted to the data $\left(j, E_{j}\right)$ by a least-squares method. Table 3.1 gives the calibration coefficients $A_{j}$ for the polynomial

$E(k e V)=A_{0}+A_{1} C+A_{2} C^{2}+A_{3} C^{3}+A_{4} C^{4}$,

where $C$ is the channel number, with a digital offset of 40 channels.

Table 3.1. Energy Calibration

\begin{tabular}{|c|c|c|}
\hline & Region 1 & Region 2 \\
\hline Coefficient & Channels $1-400$ & Channels $401-4000$ \\
\hline$A_{0}$ & $2.040168 \mathrm{E}+1$ & $2.391331 \mathrm{E}+1$ \\
\hline$A_{1}$ & $3.555993 \mathrm{E}-1$ & $3.477040 \mathrm{E}-1$ \\
\hline $\mathrm{A}_{2}$ & $1.945887 \mathrm{E}-4$ & $-1.763261 \mathrm{E}-6$ \\
\hline $\mathbf{A}_{3}$ & $-8.920941 \mathrm{E}-7$ & $2.418152 E-10$ \\
\hline $\mathbf{A}_{4}$ & $1.007525 \mathrm{E}-9$ & 0 \\
\hline
\end{tabular}


Figure 3.9 shows the data $\left(j, E_{j}\right)$ superimposed on the calculated calibration curve for the region of channels 1-400 (\#1). Figure 3.10 shows the residuals, i.e., calculated energy minus observed energy, for region \#1. The maximum difference of $0.15 \mathrm{keV}$ between the observed and the calculated energies may be partially due to the error in centroid location and the energy assignment. Similarly, the calibration curve for region \#2 (channels 401-4000) is shown in Figure 3.11 and the residuals in Figure 3.12. In region $\# 2$, the maximum residual error is $0.17 \mathrm{keV}$.

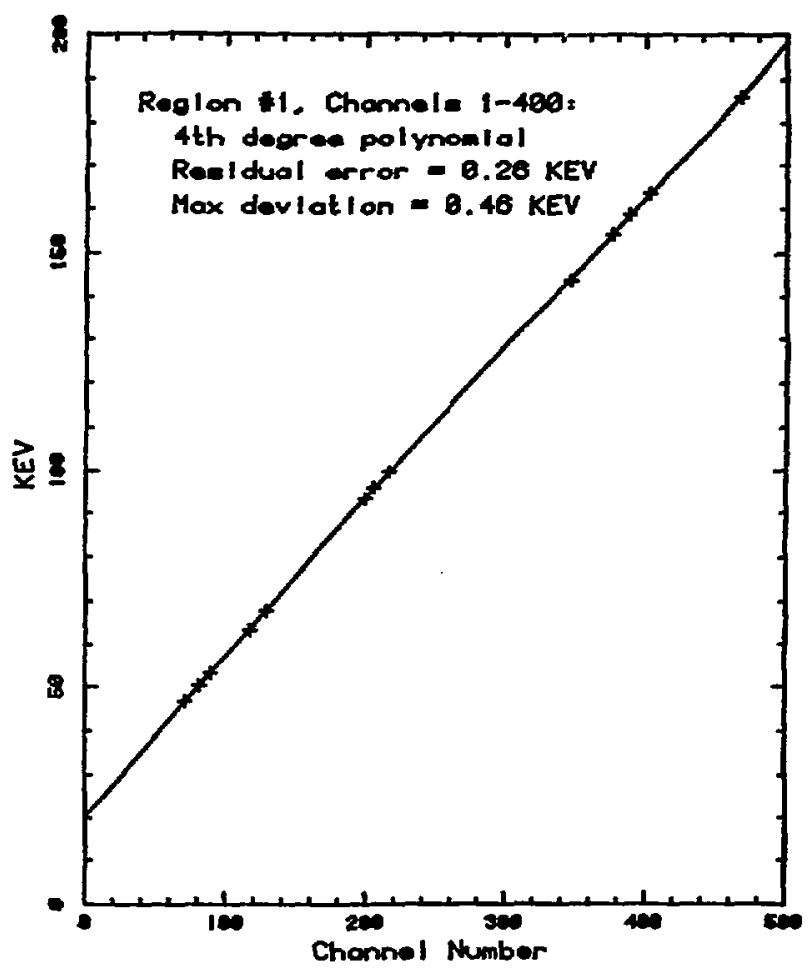

Figure 3.9. Energy Calibration of Gama Spectra, $0-200 \mathrm{keV}$. 


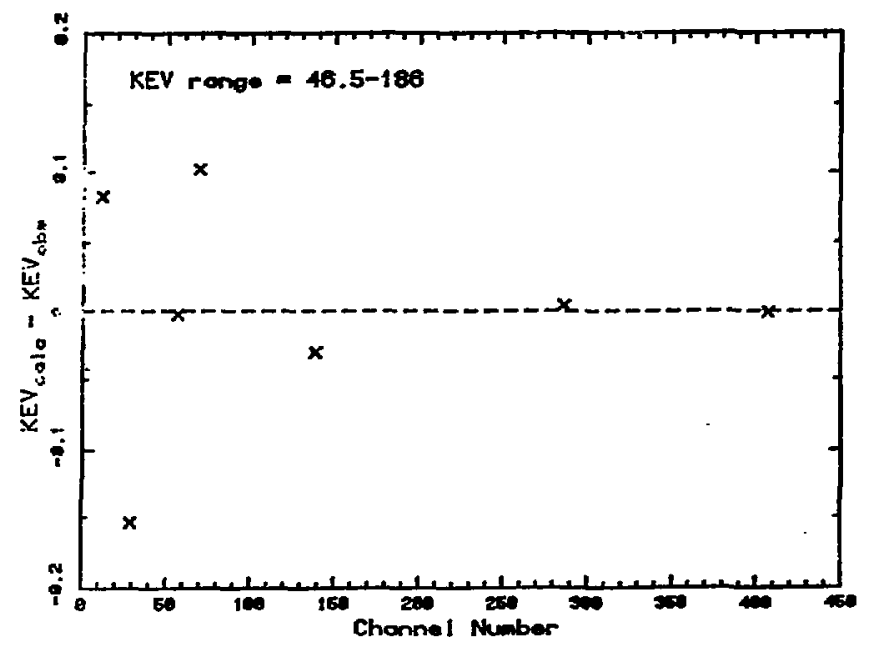

Figure 3.10. Calculated Energy Minus Observed Energy (residuals) of Gamma Spectral Energy Calibration for Region 1.

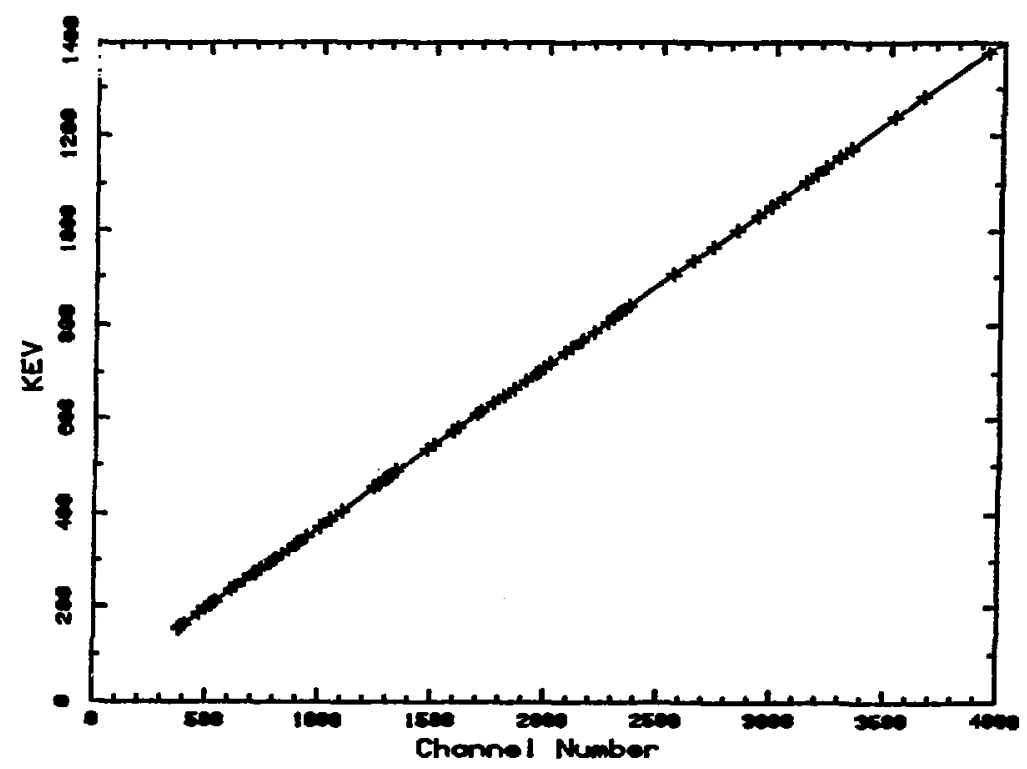

Figure 3.11. Energy Calibration of Gama Spectra, $200-1400 \mathrm{keV}$. 


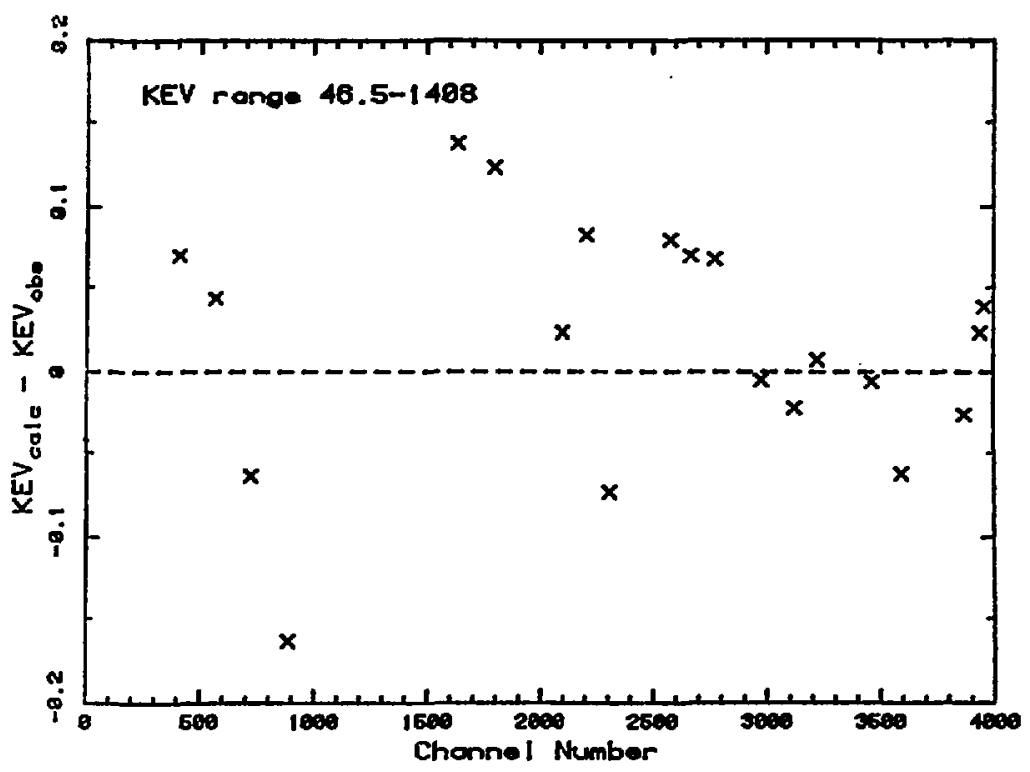

Figure 3.12. Calculated Energy Minus Observed

Energy (residuals) of Gamma

Spectral Energy Calibration.

\subsubsection{Efficiency Calibration}

An efficiency calibration is a deternination of the functional relationship between the total detection efficiency $\varepsilon_{j}$, where

$$
\varepsilon_{j}=\frac{n_{p j}}{2.22 A_{p j} b_{p j}}
$$

and energy $E_{j}$. To generate a data set $\left(E_{j}, \varepsilon_{j}\right)$, a calibration spectrum is deconvoluted, and the optimized peak shape parameters are calculated. On the basis of this analysis and a known set of data $\left(E_{j}, 2.22 A_{p j} b_{p j}\right), E_{j}$ and $\varepsilon_{j}$ are calculated. The total efficiency, $\varepsilon_{j}$, is the detected fraction of the 
photons of energy $E_{j}$ emitted by the source. The $\varepsilon_{j}$ is dependent on a conbination of factors: sample shape, sample-detector geometry, sample selfabsorption, and intrinsic efficiency of the detector. The observed efficiency (Fig. 3.13) initially increases with increasing energy to a maximum value; thereafter, it decreases exponentially with increasing energy. The efficiency curve can be divided into several energy regions, and the data in each region

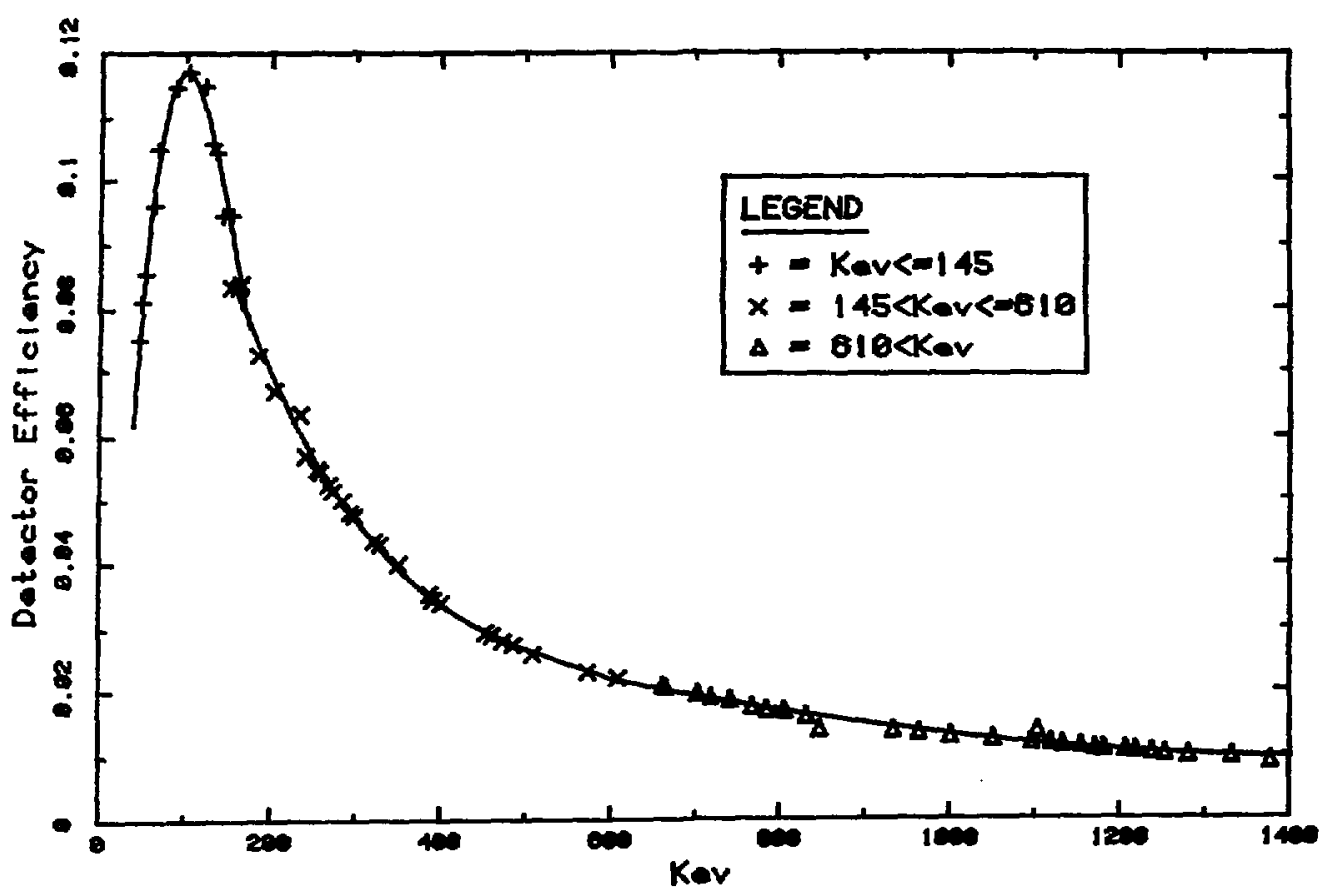

Figure 3.13. Calculated Efficiency and Measured Efficiency as a Function of Photon Energy.

are then fitted to a sum of exponential functions or to the following polynomial:

$$
\varepsilon=A_{0}+A_{1} E+A_{2} E^{2}+A_{3} E^{3}+A_{1} E^{4},
$$

calculated from a least-squares fit of the data $\left(E_{j}, \varepsilon_{j}\right)$ to three energy regions: 40-145 keV, $145-610 \mathrm{keV}$, and $510-1500 \mathrm{keV}$. The coefficients $A_{i}$ of 
the polynomial are listed in Appendix B. The optimized peak width (FWHM) is a function of energy (E) and can be estimated by

$$
\left(\frac{\text { FWHM }}{2}\right)^{2}=R_{0}+R_{1} E \text {, }
$$

where $R_{0}=3.032$ and $R_{1}=3.69 \times 10^{-3}$. The peak shape parameter joining the central Gaussian to the low-energy exponential skewing functions is 1.833 FWHM/2. The ration of the step height to the central Gaussian height is $3.018 \times 10^{2}$.

4. GAMMA SPECTRA OF THE URANIUM, ACTINIUM, AND THORIUM DECAY SERIES

\subsection{Gamma Energies and Quantum Yields}

Tabiles 4.1 and 4.2 list the gamma peaks detected in samples of ore containing the uranium, actinium, and thorium decay series, each series in secular radioactive equilibrium. The energy, error of the energy assignment, peak width, count rate, and error of the area under each peak are given for each peak listed in the tables. The nuclides corresponding to the detected peaks and the quantum yields are given in Tables 4.3 through 4.5. Figures 4.1 through 4.9 show the spectra of the gamma lines from the nuclides in the uranium, actinium, and thorium series. The spectra are superimposed on the same graph within each energy region for ease of comparison. In Tables 4.6 through 4.8, the energies and quantum yields measured in this investigation are compared with those previously reported. Because the $70-115 \mathrm{keV}$ region (Fig. 4.2) includes lines from X-ray emissions, the gamma line intensities were not estimated in this region, except for peaks at $92.75 \mathrm{keV}$ (Th-234) and $109.15 \mathrm{keV}(\mathrm{U}-235)$ (see Tables 4.3 and 4.4).

The lowest energy peak detected in the spectrum of the uranium and actiniun series (Table 4.1 ) is at $46.50 \mathrm{keV}$, and its origin is the decay of $\mathrm{Pb}-210$. The quantum yield of this line is $4.10 \times 10^{-2}$, in good agreement with those previously reported (Table 4.6). In addition to this line, five other peaks are identifiable in Figure 4.1 , and of these, three peaks also seem to be present in the thorium spectrum. The line at $57.62 \mathrm{keV}$ is a reference line (pulse line) for comparison of the spectra. The thorium ore sample also contains uranium and actinium nuclides. 
The second peak in the uranium spectrum was resolved into two peaks, $49.09 \mathrm{keV}$ and $50.11 \mathrm{keV}$ (Table 4.1), from Th-227, and Fr-223 at $49.8 \mathrm{keV}$ also contributes to this peak (Table 4.4). The third peak was resolved into three peaks at $52.14,52.77$ and $53.18 \mathrm{keV}$ (Table 4.1). The origin of the 52.77-keV line is uncertain. Smith and Wollenberg (1972) assigned the 52.14-keV line to $\mathrm{Pb}-214$ and the 53.18-keV peak to U-234, but Lingeman et al. (1969) assigned the 53.23-keV peak to $\mathrm{Pb}-214$. The quantum yields for the U-234 line are in good agreement with the values reported by Suith and Wollenberg (1972), but the quantum yields for the $\mathrm{Pb}-214$ line are about $50 \%$ of previously reported values.

The peak at $63.42 \mathrm{keV}$ (Fig. 4.1 and Table 4.1) was resolved into two peaks, $63.30 \mathrm{keV}$ and $63.4 \mathrm{keV}$, and was assigned, respectively, to Th-234 and $\mathrm{Pa}-234$ (Smith and Wollenberg 1972). Godard and Gizon (1973) also resolved the peak into $62.92 \mathrm{keV}$ and $63.35 \mathrm{keV}$ lines and assigned both to Th-234. Heath (1975) assigned the peak at $63.3 \mathrm{keV}$ to Pa-231 and Th-234. Bjornholm et al. (1968), Sampson (1973), and Chu and Scharff-Goldhaber (1978) reported the peak at $63.4 \mathrm{keV}, 63.28 \mathrm{keV}$, and $63.1 \mathrm{keV}$, respectively. Taylor (1973) also resolved the peak to a doublet at 62.97 and $63.35 \mathrm{keV}$ and attributed both to Th-234. Another peak observed at $61.18 \mathrm{keV}$ was assigned to Bi-214. The peak at $67.67 \mathrm{keV}$ (Fig. 4.1) is due to Th-230 and is the only line useful for measurement of this nuclide. The energy and intensity reported in the literature compare favorably with those measured in this study (Table 4.6).

In the thorium series, the lowest energy detected (Table 4.2) was at $37.8 \mathrm{keV}$ (not shown in Fig. 4.1). The origin of this line is uncertain. The next peak at $39.90 \mathrm{keV}$ is from Bi-212 (Table 4.6). The other lines are from the uranium and actinium series. Because the 70-120 keV region includes lines from $X$-ray emissions (Fig. 4.2), the intensities for this region were not estimated except for the lines at $92.75 \mathrm{keV}(\mathrm{Pa}-234), 109.15 \mathrm{keV}$ and $115.20 \mathrm{keV}$ (U-235), and $113.08 \mathrm{keV}$ (Th-227). The characteristic X-ray lines for elevents contributing to the gamma spectra were previously reported (Lederer et al. 1968). The lines detected in the $70-120 \mathrm{keV}$ energy region are listed in Tables 4.1 and 4.2. The prominent peaks in this energy region (Fig. 4.3) are at $143.82 \mathrm{keV}(\mathrm{U}-235, \mathrm{Th}-230, \mathrm{Ra}-223), 154.15 \mathrm{keV}(\mathrm{Ra}-223), 163.45 \mathrm{keV}$ (U-235), and $185.93 \mathrm{keV}(\mathrm{U}-235, \mathrm{Ra}-226)$ in the uranium and actinium series, and $129.07 \mathrm{keV}(\mathrm{Ac}-228)$ in the thorium series. 
The lines from the nuclides in the uranium and actinium series, which were also observed in the thorium spectrum, are at $154.15 \mathrm{keV}$ and $185.93 \mathrm{keV}$. The peak at $163.45 \mathrm{keV}$ from the decay of U-235 has often been utilized for correction of the U-235 contribution to the unresolved lines (U-235 + Ra-226) at $185.93 \mathrm{keV}$ for a direct measuresent of Ra-226. For both lines, the energy and the quantum yield for U-235 are in good agreement with previously reported values (Table 4.7), but the quantum yield for Ra-226 is about $20 \%$ lower than those reported in the literature.

Tables 4.1 and 4.2 identify the most intense peaks observed in the spectra shown in Figures 4.3 through 4.5. The most suitable peaks for determination of activity are the intense peaks that are not complicated by interference. When the interference may be accounted for by other lines from the same nuclide, the peaks with interference can also be utilized for calculation of activities. However, in cases where the interference lines cannot be accounted for by other lines, the activities cannot be unambiguously determined. In some situations, the contribution from the interference lines is very weak, and the activity could be estimited, even though che magnitude of the interference is not computable.

The quantum yields measured in this investigation are generally of the same order of magnitude as those previously reported (Tables 4.6 through 4.8) but, in general, there is more favorable agreement for the more intense lines. The energies of the lines measured in this research are in good agreement with the previously reported values and within a fraction of a keV of the more recent measurements.

\subsection{Conclusion}

In general, the magnitude of the uncertainty associated with the computed quantum yield depends on the magnitude of the full width of the energy peak and the area under the peak, relative to the background continuum and the magnitude of the interferences. The uncertainty of estimating the contribution from the interference peaks is related to the magnitude of the uncertainty in the quantum yields and the uncertainty in the deconvolution method 
for resolution of the multiplets. The uncertainty in the quantum yieids of less than $1 \times 10^{-3}$ is smaller than $5 \%$ for the lines free from interference and more than $10 \%$ for the others. The uncertaincy arises from the composite errors of deconvolution, the uncertainty in the absolute activity of the primary standards, and the magnitude of the interference. This gamma spectroscopy system and the procedure for data reduction permit measurements of concentrations of the nuclides in uranium ore and tailings with total errors of less than $5 \%$, and, for typical environmental concentrations, with total errors of less than $15 \%$. 
Table 4.1. Detected Peaks in a Sample of Ore Containing Uranium and Actinium Series in Secular Radioactive Equilibrium

\begin{tabular}{cccc}
\hline $\begin{array}{c}\text { Energy } \pm \text { Error } \\
(\mathrm{keV})\end{array}$ & $\begin{array}{c}\text { FWHM } \\
(\mathrm{keV})\end{array}$ & $\begin{array}{c}\text { Count Rate } \\
(\mathrm{CPs})\end{array}$ & $\begin{array}{c}\text { Error } \\
(\%)\end{array}$ \\
\hline $46.50 \pm 0.01^{\mathrm{a}}$ & 1.14 & $5.480 \mathrm{E}-1$ & 1.3 \\
$49.07 \pm 0.45^{\mathrm{a}}$ & 1.14 & $5.088 \mathrm{E}-2$ & 4.45 \\
$50.11 \pm 0.14^{\mathrm{a}}$ & 1.14 & $5.088 \mathrm{E}-2$ & 4.45 \\
$52.14 \pm 0.27^{\mathrm{a}}$ & 1.14 & $1.836 \mathrm{E}-1$ & 2.20 \\
$53.18 \pm 0.04^{\mathrm{a}}$ & 1.14 & $1.836 \mathrm{E}-1$ & 2.20 \\
$63.34 \pm 0.01^{\mathrm{a}}$ & 1.13 & $7.176 \mathrm{E}-1$ & 0.75 \\
$67.67 \pm 0.05^{\mathrm{a}}$ & 1.13 & $7.490 \mathrm{E}-2$ & 2.40 \\
$74.88 \pm 0.01^{\mathrm{a}, \mathrm{b}}$ & 1.18 & $1.294 \mathrm{E} 0$ & 0.80 \\
$77.21 \pm 0.01^{\mathrm{a}, \mathrm{b}}$ & 1.18 & $2.342 \mathrm{E} 0$ & 0.55 \\
$79.46 \pm 0.05^{\mathrm{a}, \mathrm{b}}$ & 1.18 & $2.221 \mathrm{E}-1$ & 3.35 \\
$81.30 \pm 0.05^{\mathrm{a}, \mathrm{b}}$ & 1.18 & $1.842 \mathrm{E}-1$ & 3.90 \\
$84.16 \pm 0.03$ & 1.30 & $4.723 \mathrm{E}-1$ & 8.40 \\
$87.65 \pm 0.01$ & 1.27 & $7.375 \mathrm{E}-1$ & 1.15 \\
$90.39 \pm 0.02^{\mathrm{a}, \mathrm{b}}$ & 1.27 & $3.187 \mathrm{E}-1$ & 1.15 \\
$93.23 \pm 0.01^{\mathrm{a}, \mathrm{b}}$ & 1.27 & $1.125 \mathrm{E} 0$ & 0.60 \\
$95.38 \pm 0.03^{\mathrm{a}, \mathrm{b}}$ & 1.27 & $1.400 \mathrm{E}-1$ & 1.55 \\
$99.19 \pm 0.03^{\mathrm{a}, \mathrm{b}}$ & 1.48 & $1.187 \mathrm{E}-1$ & 3.10 \\
$103.52 \pm 0.19$ & 1.45 & $7.937 \mathrm{E}-2$ & 14.25 \\
$106.62 \pm 0.15^{\mathrm{a}}$ & 1.45 & $2.194 \mathrm{E}-3$ & 84.70 \\
$110.07 \pm 0.10$ & 1.45 & $1.655 \mathrm{E}-1$ & 6.10 \\
$111.97 \pm 0.09$ & 1.45 & $2.331 \mathrm{E}-1$ & 4.75 \\
$113.86 \pm 0.04$ & 1.45 & $5.385 \mathrm{E}-2$ & 4.45 \\
$115.68 \pm 0.15$ & 1.45 & $7.985 \mathrm{E}-2$ & 11.05 \\
$123.75 \pm 0.33^{\mathrm{a}}$ & 1.14 & $1.354 \mathrm{E}-2$ & 18.70 \\
$131.49 \pm 0.33$ & 1.20 & $9.085 \mathrm{E}-3$ & 17.55 \\
$139.87 \pm 0.30$ & 1.25 & $1.189 \mathrm{E}-2$ & 13.75 \\
$144.24 \pm 0.03$ & 1.25 & $1.423 \mathrm{E}-1$ & 1.85 \\
$154.25 \pm 0.06$ & 1.35 & $5.655 \mathrm{E}-2$ & 3.10 \\
$158.39 \pm 0.51$ & 1.35 & $3.821 \mathrm{E}-2$ & 18.70 \\
$163.45 \pm 0.06$ & 1.29 & $5.035 \mathrm{E}-2$ & 7.90 \\
$165.50 \pm 0.01$ & 1.29 & $4.658 \mathrm{E}-3$ & 32.35
\end{tabular}


Table 4.1 (cont'd)

\begin{tabular}{|c|c|c|c|}
\hline$\underset{(\mathrm{keV})}{\operatorname{Energy} \pm}$ Error & $\begin{array}{l}\text { FWHM } \\
\text { (keV) }\end{array}$ & $\begin{array}{c}\text { Count Rate } \\
\text { (cps) }\end{array}$ & $\begin{array}{c}\text { Error } \\
(\%)\end{array}$ \\
\hline $186.04 \pm 0.01$ & 1.29 & $1.031 E 00$ & 0.35 \\
\hline $188.72 \pm 0.49$ & 1.49 & $4.339 \mathrm{E}-2$ & 25.55 \\
\hline $195.85 \pm 0.24^{\mathrm{a}}$ & 1.56 & $1.220 \mathrm{E}-2$ & 15.53 \\
\hline $202.04 \pm 0.17$ & 1.37 & $4.563 \mathrm{E}-2$ & 12.30 \\
\hline $205.27 \pm 0.04$ & 1.15 & $3.396 \mathrm{E}-2$ & 7.50 \\
\hline $210.45 \pm 0.16$ & 1.05 & $6.552 \mathrm{E}-3$ & 14.70 \\
\hline $235.90 \pm 0.05$ & 1.18 & $6.094 \mathrm{E}-2$ & 2.40 \\
\hline $241.92 \pm 0.01$ & 1.23 & $8.933 E-1$ & 0.30 \\
\hline $253.73 \pm 0.87$ & 1.27 & $6.664 \mathrm{E}-3$ & 50.60 \\
\hline $256.18 \pm 0.04$ & 1.21 & $3.246 \mathrm{E}-2$ & 4.45 \\
\hline $258.44 \pm 0.32$ & 1.21 & $5.769 \mathrm{E}-2$ & 3.15 \\
\hline $259.09 \pm 0.40$ & 1.21 & $3.785 \mathrm{E}-3$ & 32.10 \\
\hline $269.41 \pm 0.02$ & 1.25 & $6.894 \mathrm{E}-2$ & 1.60 \\
\hline $271.20 \pm 0.02$ & 1.25 & $5.572 \mathrm{E}-2$ & 1.60 \\
\hline $273.53 \pm 0.40$ & 1.25 & $9.239 \mathrm{E}-3$ & 13.45 \\
\hline $274.75 \pm 0.05$ & 1.25 & $3.412 \mathrm{E}-2$ & 4.35 \\
\hline $281.09 \pm 0.25$ & 1.30 & $3.013 E-2$ & 12.30 \\
\hline $283.63 \pm 0.36$ & 1.30 & $3.539 \mathrm{E}-3$ & 27.90 \\
\hline $286.12 \pm 0.10$ & 1.30 & $7.548 \mathrm{E}-3$ & 14.80 \\
\hline $295.16 \pm 0.0$ & 1.26 & $1.859 \mathrm{E} 00$ & 0.30 \\
\hline $299.93 \pm 0.13^{\mathrm{a}}$ & 1.26 & $1.437 \mathrm{E}-2$ & 8.40 \\
\hline $302.64 \pm 0.30^{\mathrm{a}}$ & 1.43 & $6.816 \mathrm{E}-2$ & 12.95 \\
\hline $304.55 \pm 0.40^{\mathrm{a}}$ & 1.43 & $5.125 \mathrm{E}-2$ & 16.00 \\
\hline $314.34 \pm 0.25$ & 1.14 & $1.3930 E-2$ & 14.35 \\
\hline $323.84 \pm 0.06$ & 1.24 & $1.540 \mathrm{E}-2$ & 6.75 \\
\hline $329.80 \pm 0.07$ & 1.44 & $1.219 E-2$ & 8.30 \\
\hline $333.97 \pm 0.19^{a}$ & 1.44 & $6.511 \mathrm{E}-2$ & 8.20 \\
\hline $338.29 \pm 0.87^{a}$ & 1.44 & $6.532 E-2$ & 8.20 \\
\hline $351.89 \pm 0.01$ & 1.48 & $2.953 \mathrm{EO}$ & 0.20 \\
\hline $371.80 \pm 0.31$ & 1.44 & $1.567 \mathrm{E}-2$ & 16.50 \\
\hline $386.83 \pm 0.05$ & 1.49 & $1.765 \mathrm{E}-2$ & 2.10 \\
\hline $388.92 \pm 0.04$ & 1.49 & $2.375 E-2$ & 1.60 \\
\hline $401.84 \pm 0.04$ & 1.49 & $2.088 \mathrm{E}-2$ & 2.75 \\
\hline
\end{tabular}


Table 4.1 (cont'd)

\begin{tabular}{|c|c|c|c|}
\hline $\begin{array}{c}\text { Energy } \pm \text { Error } \\
(\mathrm{keV})\end{array}$ & $\begin{array}{l}\text { FWHM } \\
\text { (keV) }\end{array}$ & $\begin{array}{l}\text { Count Rate } \\
\text { (cps) }\end{array}$ & $\begin{array}{c}\text { Error } \\
(\%)\end{array}$ \\
\hline $404.89 \pm 0.24$ & 1.49 & $1.333 \mathrm{E}-2$ & 11.05 \\
\hline $405.74 \pm 0.32$ & 1.49 & $6.658 \mathrm{E}-3$ & 20.45 \\
\hline $426.83 \pm 0.32$ & 2.24 & $8.352 E-3$ & 23.00 \\
\hline $444.92 \pm 0.26$ & 1.53 & $3.961 \mathrm{E}-3$ & 9.75 \\
\hline $454.75 \pm 0.05$ & 1.46 & $1.412 \mathrm{E}-2$ & 2.40 \\
\hline $461.80 \pm 0.15$ & 1.94 & $1.119 \mathrm{E}-2$ & 3.95 \\
\hline $469.68 \pm 0.09$ & 1.63 & $5.506 \mathrm{E}-3$ & 3.35 \\
\hline $474.60 \pm 0.12$ & 1.63 & $4.379 E-3$ & 3.25 \\
\hline $477.12 \pm 00$ & 1.63 & $3.245 \mathrm{E}-3$ & 61.55 \\
\hline $480.55 \pm 0.05$ & 1.63 & $1.908 \mathrm{E}-2$ & 1.40 \\
\hline $487.16 \pm 0.04$ & 1.63 & $2.200 \mathrm{E}-2$ & 2.00 \\
\hline $509.96 \pm 0.22$ & 2.36 & $2.762 \mathrm{E}-2$ & 5.40 \\
\hline $511.89 \pm 0.36$ & 2.36 & $2.762 \mathrm{E}-2$ & 6.90 \\
\hline $533.78 \pm 0.09^{a}$ & 1.43 & $1.071 \mathrm{E}-2$ & 4.70 \\
\hline $543.56 \pm 0.20^{2}$ & 1.81 & $4.279 \mathrm{E}-3$ & 9.90 \\
\hline $547.21 \pm 0.40^{\mathrm{a}}$ & 1.81 & $1.130 \mathrm{E}-2$ & 18.40 \\
\hline $572.70 \pm 0.37$ & 1.84 & $2.676 \mathrm{E}-3$ & 16.05 \\
\hline $580.32 \pm 0.04$ & 1.60 & $1.421 \mathrm{E}-2$ & 2.50 \\
\hline $595.85 \pm 24$ & 1.51 & $6.539 \mathrm{E}-3$ & 9.35 \\
\hline $609.27 \pm 0.01^{a}$ & 1.66 & $1.789 \mathrm{E} 00$ & 0.30 \\
\hline $615.98 \pm 0.18^{a}$ & 1.66 & $1.255 \mathrm{E}-2$ & 29.05 \\
\hline $633.26 \pm 0.27$ & 1.99 & $1.855 \mathrm{E}-2$ & 18.50 \\
\hline $639.57 \pm 0.39$ & 1.99 & $1.167 \mathrm{E}-2$ & 19.35 \\
\hline $649.34 \pm 0.20$ & .1 .41 & $1.239 \mathrm{E}-2$ & 12.60 \\
\hline $665.42 \pm 0.02$ & 1.67 & $4.716 \mathrm{E}-2$ & 0.80 \\
\hline $683.13 \pm 0.29$ & 1.41 & $1.388 \mathrm{E}-3$ & 18.35 \\
\hline $688.54 \pm 0.53$ & 1.81 & $1.868 \mathrm{E}-2$ & 21.80 \\
\hline $698.23 \pm 0.54^{a}$ & 1.84 & $1.200 \mathrm{E}-2$ & 21.25 \\
\hline $703.22 \pm 0.07$ & 1.57 & $1.498 \mathrm{E}-2$ & 4.80 \\
\hline $710.84 \pm 0.60$ & 1.66 & $2.270 \mathrm{E}-3$ & 31.30 \\
\hline $719.83 \pm 0.05$ & 1.68 & $1.175 \mathrm{E}-2$ & 2.95 \\
\hline $733.99 \pm 0.31$ & 1.73 & $1.260 \mathrm{E}-2$ & 15.70 \\
\hline
\end{tabular}


Table 4.1 (cont'd)

\begin{tabular}{cccr}
\hline $\begin{array}{c}\text { Energy } \pm \text { Error } \\
(\mathrm{keV})\end{array}$ & $\begin{array}{c}\text { FWHM } \\
(\mathrm{keV})\end{array}$ & $\begin{array}{c}\text { Count Rate } \\
(\mathrm{cps})\end{array}$ & $\begin{array}{r}\text { Error } \\
(\%)\end{array}$ \\
\hline $742.54 \pm 0.06$ & 1.97 & $1.504 \mathrm{E}-2$ & 2.65 \\
$752.78 \pm 0.14$ & 1.69 & $3.518 \mathrm{E}-3$ & 5.65 \\
$766.28 \pm 0.07$ & 1.77 & $1.449 \mathrm{E}-2$ & 1.90 \\
$768.37 \pm 0.01$ & 1.77 & $1.476 \mathrm{E}-1$ & 0.95 \\
$785.97 \pm 0.03$ & 1.86 & $3.798 \mathrm{E}-2$ & 0.95 \\
$799.48 \pm 0.34$ & 1.79 & $9.068 \mathrm{E}-3$ & 15.40 \\
$806.28 \pm 0.02$ & 1.79 & $3.475 \mathrm{E}-2$ & 1.15 \\
$815.05 \pm 0.43$ & 1.86 & $9.349 \mathrm{E}-3$ & 14.45 \\
$821.28 \pm 0.11$ & 1.86 & $4.470 \mathrm{E}-3$ & 3.40 \\
$826.13 \pm 0.13$ & 1.86 & $4.003 \mathrm{E}-3$ & 4.85 \\
$832.06 \pm 0.10$ & 1.86 & $6.085 \mathrm{E}-3$ & 3.70 \\
$839.10 \pm 0.03$ & 1.86 & $2.037 \mathrm{E}-2$ & 2.10 \\
$846.80 \pm 0.30$ & 1.43 & $1.648 \mathrm{E}-2$ & 20.40 \\
$904.27 \pm 0.20$ & 1.50 & $1.170 \mathrm{E}-2$ & 11.35 \\
$934.09 \pm 0.02$ & 1.86 & $7.638 \mathrm{E}-2$ & 0.55 \\
$945.99 \pm 0.27$ & 0.90 & $4.388 \mathrm{E}-3$ & 19.25 \\
$964.10 \pm 0.07$ & 1.90 & $9.339 \mathrm{E}-3$ & 3.00 \\
$1001.04 \pm 0.03$ & 1.91 & $2.356 \mathrm{E}-2$ & 1.30 \\
$1032.24 \pm 0.30$ & 2.42 & $1.528 \mathrm{E}-2$ & 11.00 \\
$1048.42 \pm 0.07 \mathrm{a}$ & 1.19 & $8.252 \mathrm{E}-3$ & 13.35 \\
$1051.92 \pm 0.09$ & 1.19 & $6.903 \mathrm{E}-3$ & 5.35 \\
$1069.95 \pm 0.10$ & 1.80 & $6.103 \mathrm{E}-3$ & 4.40 \\
$1103.92 \pm 0.17$ & 2.47 & $3.124 \mathrm{E}-3$ & 7.80 \\
$1120.21 \pm 0.01^{\mathrm{a}}$ & 1.98 & $3.220 \mathrm{E}-1$ & 0.25 \\
$1133.76 \pm 0.15$ & 2.00 & $4.588 \mathrm{E}-3$ & 4.70 \\
$1155.12 \pm 0.02$ & 2.01 & $3.682 \mathrm{E}-2$ & 0.80 \\
$1173.08 \pm 0.32$ & 2.21 & $1.721 \mathrm{E}-3$ & 11.90 \\
$1182.01 \pm 0.07$ & 2.11 & $5.782 \mathrm{E}-2$ & 3.35 \\
$1207.62 \pm 0.09$ & 2.05 & $6.660 \mathrm{E}-2$ & 2.80 \\
$1217.36 \pm 0.38$ & 1.25 & $4.684 \mathrm{E}-3$ & 22.90 \\
$1218.89 \pm 0.33$ & 1.25 & $6.578 \mathrm{E}-3$ & 20.30 \\
$1238.07 \pm 0.01$ & 2.06 & $8.4812 \mathrm{E}-1$ & 0.40
\end{tabular}


Table 4.1 (cont'd)

\begin{tabular}{cccr}
\hline $\begin{array}{c}\text { Energy } \pm \text { Error } \\
(\mathrm{keV})\end{array}$ & $\begin{array}{c}\text { FWHM } \\
(\mathrm{keV})\end{array}$ & $\begin{array}{c}\text { Count Rate } \\
(\mathrm{cps})\end{array}$ & $\begin{array}{c}\text { Error } \\
(\%)\end{array}$ \\
\hline $1253.39 \pm 0.16$ & 2.95 & $5.620 \mathrm{E}-2$ & 2.10 \\
$1274.62 \pm 0.29$ & 2.09 & $1.1068 \mathrm{E}-2$ & 10.75 \\
$1280.95 \pm 0.03$ & 2.09 & $2.0468 \mathrm{E}-1$ & 1.35 \\
$1303.77 \pm 0.23$ & 1.95 & $1.3014 \mathrm{E}-2$ & 8.60 \\
$1317.18 \pm 0.25$ & 1.97 & $1.0301 \mathrm{E}-2$ & 11.20 \\
$1377.82 \pm 0.01$ & 2.14 & $6.1852 \mathrm{E}-1$ & 0.55 \\
$1385.49 \pm 0.04$ & 2.14 & $1.0601 \mathrm{E}-1$ & 1.10 \\
\hline
\end{tabular}

${ }_{A}$ s satisfactory $\chi^{2}$ could not be obtained, even though the peaks were allowed to vary individually. Moreover, a search for hidden peaks among the residuals revealed no additional peaks.

$b_{A}$ less than optimum peak width was used when a large number of neighboring and overlapping peaks were present. All other values represent a good fit. 
Table 4.2. Detected Peaks in a Sample of Ore Containing Uranium, Actinium, and Thorium Series in Secular Radioactive Equilibrium

\begin{tabular}{|c|c|c|c|}
\hline$\underset{(\mathrm{keV})}{\operatorname{Energy} \pm \text { Error }}$ & $\begin{array}{l}\text { FWHM } \\
\text { (keV) }\end{array}$ & $\begin{array}{c}\text { Count Rate } \\
\text { (cps) }\end{array}$ & $\begin{array}{c}\text { Error } \\
(\%)\end{array}$ \\
\hline $37.85 \pm 0.17^{a, b}$ & 1.15 & $3.6963 \mathrm{E}-01$ & 10.35 \\
\hline $39.90 \pm 0.13^{a, b}$ & 1.15 & $4.2541 E-01$ & 7.50 \\
\hline $42.69 \pm 0.60^{a, b}$ & 1.15 & $6.9917 \mathrm{E}-02$ & 34.75 \\
\hline $46.50 \pm 0.30^{b}$ & 1.06 & $1.0051 \mathrm{E}-01$ & 33.20 \\
\hline $57.62 \pm 0.08$ & 1.04 & $1.2120 \mathrm{E}-01$ & 6.05 \\
\hline $63.34 \pm 0.13$ & 1.19 & $1.9834 \mathrm{E}-01$ & 7.05 \\
\hline $74.95 \pm 0.03^{a, b}$ & 1.15 & $5.8817 \mathrm{E} \quad 00$ & 1.75 \\
\hline $77.28 \pm 0.02^{a, b}$ & 1.15 & $9.7086 \mathrm{E} \quad 00$ & 1.20 \\
\hline $81.40 \pm 0.50^{a, b}$ & 1.29 & $1.2496 \mathrm{E}-01$ & 24.75 \\
\hline $84.76 \pm 0.05^{a, b}$ & 1.29 & $1.2028 \mathrm{E} 00$ & 4.40 \\
\hline $87.71 \pm 0.02^{a, b}$ & 1.29 & $4.0596 \mathrm{E} 00$ & 3.20 \\
\hline $90.53 \pm 0.02^{a, b}$ & 1.29 & $3.1332 \mathrm{E} \quad 00$ & 3.30 \\
\hline $93.91 \pm 1.50^{a, b}$ & 1.17 & $1.1891 \mathrm{E} 00$ & 25.75 \\
\hline $94.17 \pm 1.19^{a, b}$ & 1.17 & $1.6449 \mathrm{E} 00$ & 22.95 \\
\hline $100.51 \pm 0.06$ & 1.23 & $6.9065 E-01$ & 2.05 \\
\hline $106.64 \pm 0.17^{a}$ & 1.49 & $1.0542 \mathrm{E} 00$ & 3.90 \\
\hline $110.16 \pm 2.53^{a}$ & 1.49 & $3.3004 \mathrm{E}-01$ & 4.35 \\
\hline $110.26 \pm 15.23^{a}$ & 1.49 & $6.1544 \mathrm{E}-02$ & 98.50 \\
\hline $116.90 \pm 0.05$ & 1.16 & $3.5168 \mathrm{E}-01$ & 4.00 \\
\hline $129.07 \pm 0.02$ & 1.16 & $1.3546 \mathrm{E} 00$ & 0.95 \\
\hline $131.51 \pm 0.15$ & 1.16 & $1.0935 \mathrm{E}-01$ & 5.65 \\
\hline $140.86 \pm 0.40$ & 1.06 & $2.4933 E-02$ & 26.65 \\
\hline $145.85 \pm 0.16$ & 1.13 & $7.4840 \mathrm{E}-02$ & 8.50 \\
\hline $153.99 \pm 0.04$ & 1.16 & $4.2521 \mathrm{E}-01$ & 2.00 \\
\hline $166.34 \pm 0.16$ & 0.95 & $5.1180 \mathrm{E}-02$ & 10.00 \\
\hline $176.49 \pm 0.19$ & 0.51 & $1.4198 \mathrm{E}-02$ & 16.60 \\
\hline $186.04 \pm 0.06$ & 1.29 & $2.8243 E-01$ & 2.75 \\
\hline $191.29 \pm 0.13$ & 1.11 & $5.1167 \mathrm{E}-02$ & 13.90 \\
\hline $199.41 \pm 0.08$ & 1.19 & $1.1774 \mathrm{E}-01$ & 3.95 \\
\hline $204.11 \pm 0.28$ & 1.19 & $4.6231 \mathrm{E}-02$ & 6.65 \\
\hline
\end{tabular}


Table 4.2 (cont'd)

\begin{tabular}{cccr}
\hline $\begin{array}{c}\text { Energy } \pm \text { Error } \\
(\mathrm{keV})\end{array}$ & $\begin{array}{c}\text { FWHM } \\
(\mathrm{keV})\end{array}$ & $\begin{array}{c}\text { Count Rate } \\
(\mathrm{cps})\end{array}$ & $\begin{array}{r}\text { Error } \\
(\%)\end{array}$ \\
\hline $209.24 \pm 0.01$ & 1.19 & $1.7416 \mathrm{E} 00$ & 0.65 \\
$215.94 \pm 0.10$ & 1.16 & $1.2103 \mathrm{E}-01$ & 5.30 \\
$233.29 \pm 0.32$ & 1.07 & $2.5145 \mathrm{E}-02$ & 21.20 \\
$238.62 \pm 0^{\mathrm{a}}$ & 1.22 & $1.9397 \mathrm{E} 01$ & 0.20 \\
$240.93 \pm 0.04^{\mathrm{a}}$ & 1.22 & $1.8534 \mathrm{E} 00$ & 1.15 \\
$241.92 \pm 0.21^{\mathrm{a}}$ & 1.22 & $2.6430 \mathrm{E}-01$ & 10.05 \\
$252.66 \pm 0.12$ & 1.16 & $7.6698 \mathrm{E}-02$ & 5.05 \\
$270.22 \pm 0.01$ & 1.25 & $1.1696 \mathrm{E} 00$ & 0.65 \\
$277.33 \pm 0.02$ & 1.23 & $6.9092 \mathrm{E}-01$ & 1.35 \\
$278.84 \pm 0.22$ & 1.23 & $5.4962 \mathrm{E}-02$ & 4.50 \\
$288.10 \pm 0.05$ & 1.24 & $1.2300 \mathrm{E}-01$ & 2.50 \\
$295.16 \pm 0.03$ & 1.23 & $3.7842 \mathrm{E}-01$ & 1.70 \\
$300.03 \pm 0.45$ & 1.23 & $7.1159 \mathrm{E}-01$ & 102.35 \\
$300.26 \pm 1.09$ & 1.23 & $2.6115 \mathrm{E}-01$ & 102.35 \\
$321.62 \pm 0.12$ & 1.21 & $5.1021 \mathrm{E}-02$ & 6.80 \\
$327.97 \pm 0.01^{\mathrm{b}}$ & 1.28 & $8.5833 \mathrm{E}-01$ & 0.75 \\
$332.37 \pm 0.05^{\mathrm{b}}$ & 1.28 & $1.0386 \mathrm{E}-01$ & 2.00 \\
$338.29 \pm 0.01^{\mathrm{b}}$ & 1.29 & $3.3260 \mathrm{E} 00$ & 0.35 \\
$340.86 \pm 0.06^{\mathrm{b}}$ & 1.29 & $1.0516 \mathrm{E}-01$ & 2.45 \\
$351.89 \pm 0.02$ & 1.30 & $6.2441 \mathrm{E}-01$ & 0.75 \\
$377.37 \pm 0.48$ & 1.01 & $5.5626 \mathrm{E}-02$ & 19.60 \\
$387.04 \pm 0.44$ & 1.70 & $2.2001 \mathrm{E}-02$ & 12.60 \\
$409.45 \pm 0.02$ & 1.29 & $4.1027 \mathrm{E}-01$ & 1.20 \\
$415.32 \pm 0.32$ & 1.29 & $1.9400 \mathrm{E}-02$ & 8.10 \\
$440.50 \pm 0.17$ & 0.93 & $2.0315 \mathrm{E}-02$ & 9.10 \\
$452.86 \pm 0.06$ & 1.29 & $7.5583 \mathrm{E}-02$ & 3.20 \\
$462.99 \pm 0.02$ & 1.36 & $8.1940 \mathrm{E}-01$ & 0.60 \\
$473.53 \pm 0.61$ & 1.57 & $1.2274 \mathrm{E}-02$ & 24.05 \\
$478.26 \pm 0.26$ & 1.57 & $3.1449 \mathrm{E}-02$ & 14.15 \\
$503.86 \pm 0.19$ & 1.33 & $2.3646 \mathrm{E}-02$ & 10.90 \\
$510.74 \pm 0.03^{\mathrm{a}}$ & 1.42 & $1.2793 \mathrm{E} 00$ & 1.70
\end{tabular}


Table 4.2 (cont'd)

\begin{tabular}{|c|c|c|c|}
\hline$\underset{(\mathrm{keV})}{\operatorname{Energy} \pm \text { Error }}$ & $\begin{array}{l}\text { FWHM } \\
\text { (keV) }\end{array}$ & $\begin{array}{c}\text { Count Rate } \\
\text { (cps) }\end{array}$ & $\begin{array}{c}\text { Error } \\
(\%)\end{array}$ \\
\hline $523.26 \pm 0.61$ & 1.41 & $1.0562 \mathrm{E}-02$ & 24.70 \\
\hline $546.40 \pm 0.17$ & 1.15 & $2.5278 \mathrm{E}-02$ & 13.45 \\
\hline $549.55 \pm 1.13$ & 1.15 & $1.4875 E-02$ & 78.70 \\
\hline $550.01 \pm 2.63$ & 1.15 & $5.2149 E-03$ & 102.35 \\
\hline $562.52 \pm 0.05$ & 1.39 & $1.5086 \mathrm{E}-01$ & 2.15 \\
\hline $571.42 \pm 0.34$ & 1.82 & $3.4806 \mathrm{E}-02$ & 6.95 \\
\hline $583.21 \pm 0.01$ & 1.42 & $4.3819 \mathrm{E} \quad 00$ & 0.20 \\
\hline $609.27 \pm 0.03$ & 1.46 & $3.9665 E-01$ & 1.15 \\
\hline $616.06 \pm 0.50$ & 1.02 & $7.2584 \mathrm{E}-03$ & 29.45 \\
\hline $665.90 \pm 0.40$ & 1.77 & $1.5339 \mathrm{E}-02$ & 17.60 \\
\hline $701.84 \pm 0.26$ & 1.91 & $2.6778 \mathrm{E}-02$ & 8.05 \\
\hline $707.55 \pm 0.27$ & 1.91 & $2.9936 E-02$ & 4.85 \\
\hline $727.33 \pm 0.02$ & 1.54 & $9.3788 \mathrm{E}-01$ & 0.55 \\
\hline $755.37 \pm 0.07$ & 1.52 & $1.1173 E-01$ & 2.45 \\
\hline $763.42 \pm 0.07$ & 1.42 & $6.4026 \mathrm{E}-02$ & 3.70 \\
\hline $768.37 \pm 0.15$ & 1.42 & $2.6048 \mathrm{E}-02$ & 4.95 \\
\hline $772.15 \pm 0.53$ & 1.42 & $8.8136 E-02$ & 53.65 \\
\hline $772.65 \pm 0.61$ & 1.42 & $6.8816 \mathrm{E}-02$ & 67.80 \\
\hline $782.20 \pm 0.08$ & 1.45 & $5.4418 \mathrm{E}-02$ & 4.75 \\
\hline $785.48 \pm 0.99$ & 1.45 & $7.4389 \mathrm{E}-02$ & 98.65 \\
\hline $785.83 \pm 1.24$ & 1.45 & $5.0995 \mathrm{E}-02$ & 102.35 \\
\hline $795.02 \pm 0.02$ & 1.55 & $4.5364 E-01$ & 0.80 \\
\hline $830.60 \pm 0.09$ & 1.58 & $5.3171 \mathrm{E}-02$ & 3.55 \\
\hline $835.80 \pm 0.04$ & 1.58 & $1.7216 \mathrm{E}-01$ & 1.70 \\
\hline $840.41 \pm 0.06$ & 1.58 & $9.3670 \mathrm{E}-02$ & 2.20 \\
\hline $847.05 \pm 0.29$ & 1.58 & $1.6905 \mathrm{E}-02$ & 8.45 \\
\hline $860.65 \pm 0.02$ & 1.56 & $4.8955 E-01$ & 0.75 \\
\hline $893.48 \pm 0.13$ & 1.52 & $3.3213 E-02$ & 5.30 \\
\hline $904.32 \pm 0.10$ & 1.54 & $6.0191 \mathrm{E}-02$ & 3.50 \\
\hline $911.30 \pm 0.01$ & 1.60 & $2.7159 \mathrm{E} 00$ & 0.55 \\
\hline $934.09 \pm 0.28$ & 1.72 & $1.6932 E-02$ & 9.65 \\
\hline $944.03 \pm 0.34^{b}$ & 1.71 & $1.0695 \mathrm{E}-02$ & 12.15 \\
\hline
\end{tabular}


Table 4.2 (Cont'd)

\begin{tabular}{|c|c|c|c|}
\hline$\underset{(k e V)}{\text { Energy } \pm \text { Error }}$ & $\begin{array}{l}\text { FWHM } \\
\text { (keV) }\end{array}$ & $\begin{array}{c}\text { Count Rate } \\
\text { (cps) }\end{array}$ & $\begin{array}{l}\text { Error } \\
(\%)\end{array}$ \\
\hline $947.92 \pm 0.29^{b}$ & 1.71 & $1.2247 \mathrm{E}-02$ & 11.30 \\
\hline $952.29 \pm 0.18^{b}$ & 1.71 & $1.5313 \mathrm{E}-02$ & 13.15 \\
\hline $958.70 \pm 0.16^{b}$ & 1.62 & $2.5464 E-02$ & 6.75 \\
\hline $964.87 \pm 0.03^{b}$ & 1.62 & $4.5824 \mathrm{E}-01$ & 1.10 \\
\hline $969.08 \pm 0.01^{b}$ & 1.62 & $1.5496 \mathrm{E} \quad 00$ & 0.75 \\
\hline $976.17 \pm 0.64$ & 1.92 & $3.8083 \mathrm{E}-03$ & 25.00 \\
\hline $982.40 \pm 0.38$ & 1.92 & $8.8773 E-03$ & 11.95 \\
\hline $988.27 \pm 0.21$ & 1.92 & $1.6042 \mathrm{E}-02$ & 10.25 \\
\hline $1001.04 \pm 0.27$ & 1.69 & $1.6600 \mathrm{E}-02$ & 13.85 \\
\hline $1003.72 \pm 6.18$ & 1.69 & $2.1894 \mathrm{E}-03$ & 102.35 \\
\hline $1004.59 \pm 0.99$ & 1.69 & $1.5260 \mathrm{E}-02$ & 54.35 \\
\hline $1016.47 \pm 0.45$ & 1.05 & $4.5116 \mathrm{E}-03$ & 42.65 \\
\hline $1017.73 \pm 1.61$ & 1.05 & $1.2340 \mathrm{E}-03$ & 44.90 \\
\hline $1033.39 \pm 0.20$ & 1.81 & $1.7980 \mathrm{E}-02$ & 9.50 \\
\hline $1040.08 \pm 0.51$ & 1.81 & 8.7579E-03 & 12.60 \\
\hline $1065.17 \pm 0.14$ & 1.51 & $3.2338 \mathrm{E}-02$ & 5.50 \\
\hline $1078.78 \pm 0.10$ & 1.74 & $4.5209 \mathrm{E}-02$ & 3.40 \\
\hline $1094.10 \pm 0.14^{a}$ & 2.10 & $5.8744 \mathrm{E}-02$ & 3.90 \\
\hline $1110.60 \pm 0.10$ & 1.68 & $3.9278 \mathrm{E}-02$ & 3.55 \\
\hline $1120.39 \pm 0.08$ & 1.61 & $7.1589 \mathrm{E}-02$ & 2.80 \\
\hline $1122.94 \pm 0.22$ & 1.61 & $1.8484 \mathrm{E}-02$ & 4.55 \\
\hline $1153.88 \pm 0.32$ & 2.17 & $1.6865 \mathrm{E}-02$ & 7.00 \\
\hline $1164.77 \pm 0.44$ & 1.29 & $4.1003 E-03$ & 26.05 \\
\hline $1168.72 \pm 0.49$ & 1.29 & $4.2064 \mathrm{E}-03$ & 25.60 \\
\hline $1177.54 \pm 0$ & 1.06 & $9.6006 \mathrm{E} 00$ & 0.25 \\
\hline $1178.67 \pm 0.02$ & 1.06 & $1.3705 E \quad 00$ & 0.70 \\
\hline
\end{tabular}

${ }^{\text {a } A \text { satisfactory }} \chi^{2}$ could not be obtained, even though the peaks were allowed to vary individually. Moreover, a search for hidden peaks among the residuals revealed no additional peaks.

$b_{A}$ less than optimun peak width was used when a large number of neighboring and overlapping peaks were present. All other values represent a good fit. 
Table 4.3. Energy and Quantum Yield of Selected Nuclides in the Uranium Series

\begin{tabular}{|c|c|c|c|}
\hline Energy (keV) & $\begin{array}{l}\text { Quantum } \\
\text { Yield }\end{array}$ & Energy (keV) & $\begin{array}{l}\text { Quantum } \\
\text { Yield }\end{array}$ \\
\hline Th-234 & \multicolumn{3}{|c|}{$B i-214$} \\
\hline 63.34 & $4.05 \mathrm{E}-2$ & $\begin{array}{l}303.06 \\
333.97\end{array}$ & $\begin{array}{l}8.00 \mathrm{E}-4 \\
6.00 \mathrm{E}-4\end{array}$ \\
\hline $\mathrm{Pa}-234$ & & 338.29 & $4.00 \mathrm{E}-4$ \\
\hline 131.49 & $3.98 \mathrm{E}-5$ & $\begin{array}{l}386.83 \\
388.92\end{array}$ & $5.17 \mathrm{E}-3$ \\
\hline $\begin{array}{l}733.99 \\
945.99\end{array}$ & $\begin{array}{ll}1.04 & E-4 \\
4.14 & E-4\end{array}$ & $\begin{array}{l}388.92 \\
405.74 \\
454.75\end{array}$ & $\begin{array}{ll}4.49 & E-3 \\
1.56 & E-3 \\
2.89 & E-3\end{array}$ \\
\hline \multicolumn{2}{|l|}{$\mathrm{Pa}-234 \mathrm{~m}$} & 462.24 & $2.25 \mathrm{E}-3$ \\
\hline 258.44 & $3.31 \mathrm{E}-4$ & 469.86 & $1.18 \mathrm{E}-3$ \\
\hline 742.54 & $5.00 \mathrm{E}-4$ & 474.60 & $1.06 \mathrm{E}-3$ \\
\hline 766.28 & $3.68 \mathrm{E}-3$ & 543.56 & $7.67 \mathrm{E}-4$ \\
\hline 786.27 & $6.60 \mathrm{E}-4$ & 572.70 & $1.00 \mathrm{E}-3$ \\
\hline 1001.04 & $9.20 \mathrm{E}-3$ & 609.27 & $4.33 \mathrm{E}-1$ \\
\hline & & 615.98 & $9.33 \mathrm{E}-4$ \\
\hline \multicolumn{2}{|l|}{$\mathrm{v}-234$} & 633.26 & $6.10 \mathrm{E}-4$ \\
\hline 53.18 & $1.18 \mathrm{E}-3$ & $\begin{array}{l}639.57 \\
649.34\end{array}$ & $\begin{array}{ll}2.96 & \mathrm{E}-4 \\
5.90 & \mathrm{E}-4\end{array}$ \\
\hline \multicolumn{2}{|l|}{ Th-230 } & 665.42 & $1.25 \mathrm{E}-2$ \\
\hline 67.67 & $3.63 \mathrm{E}-3$ & 683.13 & $6.74 \mathrm{E}-4$ \\
\hline 144.24 & $2.76 \mathrm{E}-4$ & $\begin{array}{l}698.23 \\
703.22\end{array}$ & $\begin{array}{ll}3.34 & \mathrm{E}-4 \\
3.93 & \mathrm{E}-3\end{array}$ \\
\hline \multicolumn{2}{|l|}{$\mathrm{Ra}-226$} & 710.84 & $7.11 \mathrm{E}-4$ \\
\hline 186.04 & $5.05 \mathrm{E}-2$ & 719.83 & $3.64 \mathrm{E}-3$ \\
\hline & & 734.30 & $4.99 \mathrm{E}-4$ \\
\hline \multicolumn{2}{|l|}{$\mathrm{Pb}-214$} & 752.97 & $1.25 \mathrm{E}-3$ \\
\hline 52.14 & $1.06 \mathrm{E}-2$ & 768.37 & $4.97 E-2$ \\
\hline 241.92 & $8.39 \mathrm{E}-2$ & 785.97 & $8.60 \mathrm{E}-3$ \\
\hline 259.09 & $5.48 \mathrm{E}-3$ & 806.28 & $1.04 \mathrm{E}-2$ \\
\hline 274.75 & $3.87 \mathrm{E}-3$ & 815.05 & $4.34 \mathrm{E}-4$ \\
\hline 295.16 & $1.15 \mathrm{E}-3$ & 821.28 & $1.30 \mathrm{E}-3$ \\
\hline 314.34 & $8.53 \mathrm{E}-4$ & 826.13 & $4.59 \mathrm{E}-4$ \\
\hline 351.89 & $3.89 \mathrm{E}-1$ & 832.06 & $1.85 \mathrm{E}-4$ \\
\hline 461.92 & $2.25 \mathrm{E}-3$ & 839.10 & $7.96 \mathrm{E}-3$ \\
\hline 480.55 & $3.82 \mathrm{E}-3$ & 934.09 & $2.95 \mathrm{E}-2$ \\
\hline 487.16 & $3.62 E-3$ & 964.10 & $3.23 \mathrm{E}-3$ \\
\hline 533.78 & $2.53 \mathrm{E}-3$ & 1032.24 & $1.18 \mathrm{E}-3$ \\
\hline 543.56 & $1.17 \mathrm{E}-3$ & 1051.92 & $2.82 \mathrm{E}-3$ \\
\hline 580.32 & $3.32 \mathrm{E}-3$ & 1069.95 & $1.98 \mathrm{E}-3$ \\
\hline 785.97 & $8.60 \mathrm{E}-3$ & 1103.92 & $1.39 \mathrm{E}-3$ \\
\hline 904.27 & $1.14 \mathrm{E}-3$ & 1120.21 & $1.46 \mathrm{E}-1$ \\
\hline & & 1133.76 & $2.46 \mathrm{E}-3$ \\
\hline \multicolumn{2}{|l|}{$\mathrm{Bi}-214$} & 1155.12 & $1.60 \mathrm{E}-2$ \\
\hline 273.53 & $3.87 \mathrm{E}-3$ & 1173.08 & $7.21 \mathrm{E}-4$ \\
\hline 281.09 & $9.14 \mathrm{E}-4$ & 1207.62 & $4.30 \mathrm{E}-3$ \\
\hline 286.12 & $3.00 \mathrm{E}-4$ & 1238.07 & $5.98 \quad \mathrm{E}-2$ \\
\hline
\end{tabular}


Table 4.3 (cont'd)

\begin{tabular}{|c|c|c|c|}
\hline Energy (keV) & $\begin{array}{l}\text { Quantum } \\
\text { Yield }\end{array}$ & Energy (keV) & $\begin{array}{l}\text { Quantum } \\
\text { Yield }\end{array}$ \\
\hline$B i-214$ & & Po-214 & \\
\hline $\begin{array}{l}1280.95 \\
1303.77 \\
1377.82 \\
1385.49\end{array}$ & $\begin{array}{ll}1.33 & \mathrm{E}-2 \\
1.04 & \mathrm{E}-3 \\
4.91 & \mathrm{E}-2 \\
7.76 & \mathrm{E}-3\end{array}$ & $\begin{array}{r}799.48 \\
\mathrm{~Pb}-210 \\
46.50\end{array}$ & $4.00 \mathrm{E}-4$ \\
\hline
\end{tabular}


Table 4.4. Energy and Quantum Yield of Selected Nuclides in the Actinium Series

\begin{tabular}{|c|c|c|c|}
\hline Energy (keV) & $\begin{array}{l}\text { Quantum } \\
\text { Yield }\end{array}$ & Energy (keV) & $\begin{array}{l}\text { Quantum } \\
\text { Yield }\end{array}$ \\
\hline $\mathrm{U}-235$ & & Fr-223 & \\
\hline 109.15 & $1.55 \mathrm{E}-2$ & 49.8 & $4.63 E-2$ \\
\hline 115.20 & $1.18 \mathrm{E}-3$ & & \\
\hline 140.76 & $1.74 \mathrm{E}-3$ & $\mathrm{Ra}-223$ & \\
\hline 143.82 & $1.05 \mathrm{E}-1$ & 123.75 & $1.00 \mathrm{E}-2$ \\
\hline 163.35 & $4.77 \mathrm{E}-2$ & 144.24 & $5.86 \mathrm{E}-2$ \\
\hline 185.72 & $5.61 \mathrm{E}-1$ & 154.25 & $7.22 \mathrm{E}-2$ \\
\hline 195.85 & $6.73 \mathrm{E}-3$ & 158.39 & $6.05 \mathrm{E}-3$ \\
\hline 202.04 & $8.64 \mathrm{E}-3$ & 269.41 & $1.50 \mathrm{E}-1$ \\
\hline 205.27 & $4.87 \mathrm{E}-2$ & 323.84 & $3.69 \mathrm{E}-2$ \\
\hline 221.38 & $1.23 \mathrm{E}-3$ & 333.84 & $4.90 \mathrm{E}-3$ \\
\hline 240.93 & $7.85 \mathrm{E}-4$ & 338.29 & $1.29 \mathrm{E}-2$ \\
\hline 246.83 & $6.17 \mathrm{E}-4$ & 371.80 & $4.40 \mathrm{E}-3$ \\
\hline & & 444.92 & $9.9 \quad E-2$ \\
\hline \multicolumn{4}{|l|}{ Th-231 } \\
\hline \multirow[t]{2}{*}{163.16} & $1.09 \mathrm{E}-2$ & \multicolumn{2}{|l|}{ Rn-219 } \\
\hline & & 130.75 & $9.66 \mathrm{E}-3$ \\
\hline \multicolumn{2}{|l|}{$\mathrm{Pa}-231$} & 271.20 & $1.20 \mathrm{E}-1$ \\
\hline 302.64 & $3.62 \mathrm{E}-2$ & 401.84 & $7.98 \mathrm{E}-2$ \\
\hline \multicolumn{2}{|l|}{ Th-227 } & \multicolumn{2}{|l|}{$\mathrm{Pb}-211$} \\
\hline 49.95 & $7.67 \mathrm{E}-2$ & 404.89 & $7.72 \mathrm{E}-2$ \\
\hline 113.08 & $6.60 \mathrm{E}-3$ & 426.90 & $1.74 \mathrm{E}-2$ \\
\hline 206.10 & $3.59 \mathrm{E}-3$ & 832.06 & $3.27 \mathrm{E}-2$ \\
\hline 210.72 & $1.10 \mathrm{E}-2$ & & \\
\hline 235.90 & $1.10 \mathrm{E}-1$ & $\mathrm{Bi}-211$ & \\
\hline 250.07 & $3.30 \mathrm{E}-3$ & 351.89 & $1.33 \mathrm{E}-1$ \\
\hline 256.18 & $7.75 \quad E-2$ & & \\
\hline 281.09 & $1.32 \mathrm{E}-3$ & & \\
\hline 286.12 & $6.90 \mathrm{E}-3$ & & \\
\hline 299.93 & $3.89 \mathrm{E}-2$ & & \\
\hline 304.55 & $9.35 \mathrm{E}-3$ & & \\
\hline 314.34 & $4.40 \mathrm{E}-3$ & & \\
\hline 329.80 & $3.45 \mathrm{E}-2$ & & \\
\hline 333.97 & $5.11 \mathrm{E}-4$ & & \\
\hline
\end{tabular}


Table 4.5. Energy and Quantum Yield of Selected Nuclides in the Thorium-232 Series

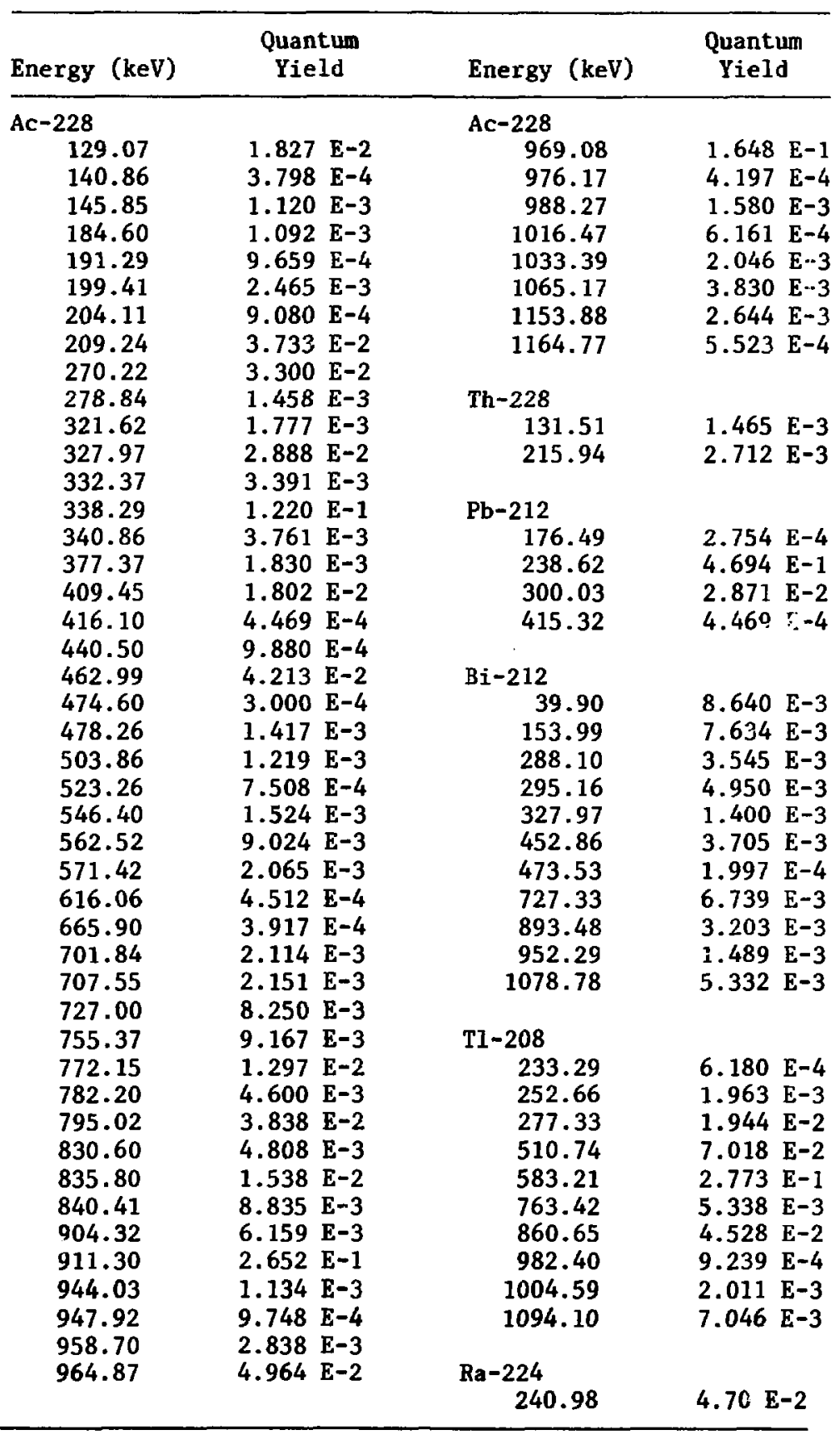


Table 4.6. Energy and Quantum Yield of Nuclides in the Uranium Series: Comparison of Values Measured in This Study with Those Previously Reported

\begin{tabular}{|c|c|c|c|}
\hline Nuclide & Energy (keV) & Quantum Yield & References \\
\hline${ }^{234} \mathrm{Th}$ & 63.34 & $4.05 \mathrm{E}-2$ & 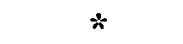 \\
\hline${ }^{234} \mathrm{Th} /{ }^{234} \mathrm{~Pa}$ & $63.30 / 63.40$ & $5.69 \mathrm{E}-2 / 6.64 \mathrm{E}-5$ & 27 \\
\hline${ }^{234} \mathrm{Th}$ & $62.92 / 63.35$ & $4.6 \mathrm{E}-3 / 4.7 \mathrm{E}-2$ & 13 \\
\hline${ }^{231} \mathrm{~Pa} /{ }^{234} \mathrm{Th}$ & 63.3 & -- & 15 \\
\hline${ }^{234} \mathrm{~Pa}$ & 63.4 & $2.8 \mathrm{E}-2$ & 2 \\
\hline${ }^{234} \mathrm{Th}$ & 63.1 & -- & 5 \\
\hline${ }^{234} \mathrm{Th}$ & 63.28 & -- & 26 \\
\hline${ }^{234} \mathrm{Th}$ & 92.75 & $1.63 \mathrm{E}-2$ & $\approx$ \\
\hline${ }^{234} \mathrm{Th}$ & $92.30 / 92.8$ & $3.15 E-2 / 3.55 E-2$ & 27 \\
\hline${ }^{234} \mathrm{Th}$ & 92.4 & -- & 5 \\
\hline${ }^{234} \mathrm{Th}$ & $92.0 / 92.38 / 92.80$ & $5 \mathrm{E}-4 / 1.45 \mathrm{E}-1 / 3.38 \mathrm{E}-2$ & 13 \\
\hline${ }^{234} \mathrm{~Pa}$ & $\begin{array}{l}131.49 \\
131.00 \\
131.00 \\
132.9\end{array}$ & $\begin{array}{ll}3.98 & E-5 \\
-- & \\
4.74 & E-4 \\
7.00 & E-4\end{array}$ & $\begin{array}{r} \pm \\
1 \\
27 \\
13\end{array}$ \\
\hline${ }^{234} \mathrm{~Pa}$ & $\begin{array}{l}733.99 \\
733.39\end{array}$ & $\begin{array}{l}1.04 \text { E-4 } \\
1.06 \text { E-4 }\end{array}$ & $\begin{array}{r}* \\
27\end{array}$ \\
\hline${ }^{234} \mathrm{~Pa}$ & $\begin{array}{l}945.99 \\
946.30 \\
946.04 \\
946.07\end{array}$ & $\begin{array}{l}4.14 \mathrm{E}-4 \\
=- \\
-- \\
3.55 \mathrm{E}-4\end{array}$ & $\begin{array}{r}* \\
2 \\
15 \\
27\end{array}$ \\
\hline $234^{\mathrm{m}} \mathrm{Pa}$ & $\begin{array}{l}258.44 \\
258.23 \\
258.23\end{array}$ & $\begin{array}{ll}3.31 & E-4 \\
7.30 & E-4 \\
-- & \end{array}$ & $\begin{array}{r} \pm \\
27 \\
2\end{array}$ \\
\hline $234^{\mathrm{m}} \mathrm{Pa}$ & $\begin{array}{l}742.54 \\
742.79\end{array}$ & $\begin{array}{l}5.00 \text { E-4 } \\
9.50 \text { E-4 }\end{array}$ & $\begin{array}{r}* \\
27\end{array}$ \\
\hline $234^{\mathrm{m}} \mathrm{Pa}$ & $\begin{array}{l}766.28 \\
766.39\end{array}$ & $\begin{array}{ll}3.68 & E-3 \\
3.13 & E-3\end{array}$ & $\begin{array}{r}* \\
27\end{array}$ \\
\hline $234^{\mathrm{m}} \mathrm{Pa}$ & $\begin{array}{l}786.27 \\
786.30\end{array}$ & $\begin{array}{ll}6.60 & E-4 \\
5.50 & E-4\end{array}$ & $\begin{array}{r}* \\
27\end{array}$ \\
\hline $234^{\mathrm{m}} \mathrm{Pa}$ & $\begin{array}{l}1001.04 \\
1001.10\end{array}$ & $\begin{array}{ll}9.20 & E-3 \\
8.28 & E-3\end{array}$ & 27 \\
\hline${ }^{234} \mathrm{U}$ & $\begin{array}{l}53.18 \\
53.30\end{array}$ & $\begin{array}{ll}1.18 & \mathrm{E}-3 \\
1.18 & \mathrm{E}-3\end{array}$ & $\begin{array}{r}* \\
27\end{array}$ \\
\hline
\end{tabular}

${ }^{\text {a }}$ The values measured in this investigation are followed by an asterisk in the reference column. 
Table 4.6 (Continued)

\begin{tabular}{|c|c|c|c|}
\hline Nuclide & Energy (keV) & Quantum Yield & References \\
\hline${ }^{230} \mathrm{Th}$ & $\begin{array}{l}67.67 \\
67.8 \\
67.7\end{array}$ & $\begin{array}{ll}3.63 & E-3 \\
3.81 & E-3 \\
3.73 & E-3\end{array}$ & $\begin{array}{r}* \\
27 \\
19\end{array}$ \\
\hline${ }^{230} \mathrm{Th}$ & $\begin{array}{l}144.24 \\
142.00 \\
143.87\end{array}$ & $\begin{array}{ll}2.76 & E-4 \\
4.51 & E-4 \\
4.83 & E-4\end{array}$ & $\begin{array}{r}* \\
27 \\
19\end{array}$ \\
\hline${ }^{226} \mathrm{Ra}$ & $\begin{array}{l}186.04 \\
186.00 \\
186.14\end{array}$ & $\begin{array}{ll}5.05 & E-2 \\
3.90 & E-2 \\
4.00 & E-2\end{array}$ & $\begin{array}{r}* \\
21,27 \\
1,14\end{array}$ \\
\hline${ }^{214} \mathrm{~Pb}$ & $\begin{array}{l}52.14 \\
53.23 \\
53.0\end{array}$ & $\begin{aligned} & 1.06 \mathrm{E}-2 \\
& 2.2 \mathrm{E}-2 \\
\sim & 1 . \mathrm{E}-2\end{aligned}$ & $\begin{array}{r}\star \\
21 \\
1\end{array}$ \\
\hline${ }^{214} \mathrm{~Pb}$ & $\begin{array}{l}241.92 \\
241.92 \\
241.97 \\
242.0\end{array}$ & $\begin{array}{l}8.39 \mathrm{E}-2 \\
7.60 \mathrm{E}-2 \\
-- \\
4.0 \mathrm{E}-2\end{array}$ & $\begin{array}{r}* \\
21 \\
30 \\
1\end{array}$ \\
\hline $214 \mathrm{~Pb}$ & $\begin{array}{l}259.09 \\
258.82\end{array}$ & $\begin{array}{l}5.48 \mathrm{E}-3 \\
8.0 \mathrm{E}-3\end{array}$ & 21 \\
\hline${ }^{214} \mathrm{~Pb}$ & $\begin{array}{l}274.75 \\
274.80\end{array}$ & $\begin{array}{l}3.87 \mathrm{E}-3 \\
7.0 \mathrm{E}-3\end{array}$ & 21 \\
\hline${ }^{214} \mathrm{~Pb}$ & $\begin{array}{l}295.16 \\
295.22 \\
295.00\end{array}$ & $\begin{array}{ll}1.15 & E-1 \\
1.89 & E-1 \\
1.90 & E-1\end{array}$ & $\begin{array}{r}* \\
21 \\
1\end{array}$ \\
\hline${ }^{214} \mathrm{~Pb}$ & $\begin{array}{l}314.34 \\
314.20\end{array}$ & $\begin{array}{ll}8.53 & E-4 \\
8.00 & E-4\end{array}$ & 21 \\
\hline${ }^{214} \mathrm{~Pb}$ & $\begin{array}{l}351.89 \\
351.99 \\
352.00\end{array}$ & $\begin{array}{ll}3.89 & E-1 \\
3.63 & E-1 \\
3.60 & E-1\end{array}$ & $\begin{array}{r}* \\
21 \\
1\end{array}$ \\
\hline${ }^{214} \mathrm{~Pb}$ & $\begin{array}{l}461.92 \\
462.10\end{array}$ & $\begin{array}{ll}2.25 & \mathrm{E}-3 \\
1.70 & \mathrm{E}-3\end{array}$ & 21 \\
\hline $214 \mathrm{~Pb}$ & $\begin{array}{l}480.55 \\
480.50\end{array}$ & $\begin{array}{ll}3.82 & \mathrm{E}-3 \\
3.40 & \mathrm{E}-3\end{array}$ & $\begin{array}{r}* \\
21\end{array}$ \\
\hline${ }^{214} \mathrm{~Pb}$ & $\begin{array}{l}487.16 \\
487.25\end{array}$ & $\begin{array}{ll}3.62 & E-3 \\
3.30 & E-3\end{array}$ & 21 \\
\hline $214 \mathrm{~Pb}$ & $\begin{array}{l}533.78 \\
533.80\end{array}$ & $\begin{array}{l}2.53 \mathrm{E}-3 \\
1.7 \mathrm{E}-3\end{array}$ & $2 *$ \\
\hline${ }^{214} \mathrm{~Pb}$ & $\begin{array}{l}543.56 \\
543.50\end{array}$ & $\begin{array}{l}1.17 \mathrm{E}-3 \\
1.0 \mathrm{E}-3\end{array}$ & 21 \\
\hline${ }^{214} \mathrm{~Pb}$ & $\begin{array}{l}580.32 \\
580.30\end{array}$ & $\begin{array}{ll}3.32 & E-3 \\
3.60 & E-3\end{array}$ & 21 \\
\hline
\end{tabular}


Table 4.6 (Continued)

\begin{tabular}{|c|c|c|c|}
\hline Nuclide & Energy (keV) & Quantum Yield & References \\
\hline $214 \mathrm{~Pb}$ & $\begin{array}{l}785.97 \\
785.95\end{array}$ & $\begin{array}{ll}8.60 & E-3 \\
8.60 & E-3\end{array}$ & 21 \\
\hline${ }^{214} \mathrm{~Pb}$ & 904.27 & $1.14 \mathrm{E}-3$ & $\stackrel{2}{\hbar}$ \\
\hline $214 \mathrm{~Pb} /{ }^{214} \mathrm{Bi}$ & 904.10 & $5.9 \mathrm{E}-3 / 7.0 \mathrm{E}-4$ & 21 \\
\hline $\begin{array}{l}214 \mathrm{Bi} \\
214 \mathrm{Bi}\end{array}$ & $\begin{array}{l}273.53 \\
273.50\end{array}$ & $\begin{array}{l}3.87 \\
8.00 \\
8-4\end{array}$ & 21 \\
\hline${ }^{214} \mathrm{Bi}$ & $\begin{array}{l}281.09 \\
281.10\end{array}$ & $\begin{array}{l}9.14 \mathrm{E}-4 \\
6.00 \mathrm{E}-4\end{array}$ & $\begin{array}{r}* \\
21\end{array}$ \\
\hline $\begin{array}{l}214 \mathrm{Bi} \\
214 \mathrm{Bi}\end{array}$ & $\begin{array}{l}286.12 \\
286.90\end{array}$ & $\begin{array}{ll}3.00 & \mathrm{E}-4 \\
3.00 & \mathrm{E}-4\end{array}$ & $\begin{array}{r}* \\
21\end{array}$ \\
\hline $\begin{array}{l}214_{\mathrm{Bi}} \\
214_{\mathrm{Bi}}\end{array}$ & $\begin{array}{l}303.06 \\
303.0\end{array}$ & $\begin{array}{l}8.00 \mathrm{E}-4 \\
8.00 \mathrm{E}-4\end{array}$ & $\begin{array}{r}* \\
21\end{array}$ \\
\hline $\begin{array}{l}214 \mathrm{Bi} \\
214 \mathrm{Bi}\end{array}$ & $\begin{array}{l}333.97 \\
334.30\end{array}$ & $\begin{array}{ll}6.00 & E-4 \\
6.00 & E-4\end{array}$ & $\begin{array}{r}* \\
21\end{array}$ \\
\hline $\begin{array}{l}214 \mathrm{Bi} \\
214 \mathrm{Bi}\end{array}$ & $\begin{array}{l}338.29 \\
338.50\end{array}$ & $\begin{array}{l}4.00 \\
4.00 \\
4.0\end{array}$ & 21 \\
\hline $\begin{array}{l}214 \mathrm{Bi} \\
214 \mathrm{Bi}\end{array}$ & $\begin{array}{l}386.83 \\
386.80\end{array}$ & $\begin{array}{ll}5.17 & E-3 \\
3.10 & E-3\end{array}$ & 21 \\
\hline${ }^{214} \mathrm{Bi}$ & $\begin{array}{l}388.92 \\
388.80\end{array}$ & $\begin{array}{ll}4.49 & \mathrm{E}-3 \\
3.70 & \mathrm{E}-3\end{array}$ & $\begin{array}{r}* \\
21\end{array}$ \\
\hline $\begin{array}{l}214 \mathrm{Bi} \\
{ }^{214} \mathrm{Bi}\end{array}$ & $\begin{array}{l}405.74 \\
405.90\end{array}$ & $\begin{array}{ll}1.56 & \mathrm{E}-3 \\
1.50 & \mathrm{E}-3\end{array}$ & $\begin{array}{r}* \\
21\end{array}$ \\
\hline $\begin{array}{l}214 \mathrm{Bi} \\
214 \mathrm{Bi}\end{array}$ & $\begin{array}{l}454.75 \\
455.00\end{array}$ & $\begin{array}{ll}2.89 & E-3 \\
2.80 & E-3\end{array}$ & 21 \\
\hline $\begin{array}{l}214 \mathrm{Bi} \\
214 \mathrm{Bi}\end{array}$ & $\begin{array}{l}462.24 \\
462.10\end{array}$ & $\begin{array}{ll}2.25 & \mathrm{E}-3 \\
2.10 & \mathrm{E}-3\end{array}$ & 21 \\
\hline $\begin{array}{l}214 \mathrm{Bi} \\
214 \mathrm{Bi}\end{array}$ & $\begin{array}{l}469.86 \\
470.60\end{array}$ & $\begin{array}{ll}1.18 & \mathrm{E}-3 \\
1.30 \mathrm{E}-3\end{array}$ & 21 \\
\hline $\begin{array}{l}214 \mathrm{Bi} \\
214 \mathrm{Bi}\end{array}$ & $\begin{array}{l}474.60 \\
474.6\end{array}$ & $\begin{array}{l}1.06 \mathrm{E}-3 \\
7.0 \mathrm{E}-4\end{array}$ & 21 \\
\hline $\begin{array}{l}214 \mathrm{Bi} \\
214 \mathrm{Bi}\end{array}$ & $\begin{array}{l}543.56 \\
543.5\end{array}$ & $\begin{array}{l}7.67 \mathrm{E}-4 \\
1.0 \mathrm{E}-3\end{array}$ & $\begin{array}{r}* \\
21\end{array}$ \\
\hline $\begin{array}{l}214 \mathrm{Bi} \\
214 \mathrm{Bi}\end{array}$ & $\begin{array}{l}572.70 \\
572.60\end{array}$ & $\begin{array}{ll}1.0 & E-3 \\
6.0 & E-4\end{array}$ & $\begin{array}{r}* \\
21\end{array}$ \\
\hline $\begin{array}{l}214 \mathrm{Bi} \\
{ }^{214} \mathrm{Bi}\end{array}$ & $\begin{array}{l}609.27 \\
609.37 \\
609.0\end{array}$ & $\begin{array}{l}4.33 \mathrm{E}-1 \\
4.28 \mathrm{E}-1 \\
4.7 \mathrm{E}-1\end{array}$ & $\begin{array}{r}\star \\
21 \\
1\end{array}$ \\
\hline $214 \mathrm{Bi}$ & $\begin{array}{l}615.98 \\
615.80\end{array}$ & 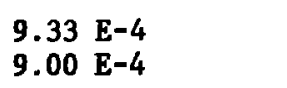 & $\begin{array}{r}\star \\
21\end{array}$ \\
\hline
\end{tabular}


Table 4.6 (Continued)

\begin{tabular}{|c|c|c|c|}
\hline Nuclide & Energy (keV) & Quantum Yield & References \\
\hline $\begin{array}{l}{ }^{214} \mathrm{Bi} \\
2^{14} \mathrm{Bi}\end{array}$ & $\begin{array}{l}633.26 \\
633.60\end{array}$ & $\begin{array}{l}6.10 \mathrm{E}-4 \\
5.0 \mathrm{E}-4\end{array}$ & 21 \\
\hline $\begin{array}{l}214_{B i} \\
214^{B i}\end{array}$ & $\begin{array}{l}639.57 \\
639.0\end{array}$ & $\begin{array}{l}2.96 \mathrm{E}-4 \\
3.0 \mathrm{E}-4\end{array}$ & 21 \\
\hline $\begin{array}{l}214 \mathrm{Bi} \\
214 \mathrm{Bi}\end{array}$ & $\begin{array}{l}649.34 \\
649.40\end{array}$ & $\begin{array}{l}5.90 \mathrm{E}-4 \\
5.0 \mathrm{E}-4\end{array}$ & 21 \\
\hline $\begin{array}{l}{ }^{214} \mathrm{Bi} \\
2^{14} \mathrm{Bi}\end{array}$ & $\begin{array}{l}665.42 \\
665.60 \\
665.0\end{array}$ & $\begin{array}{l}1.25 \mathrm{E}-2 \\
1.40 \mathrm{E}-2 \\
2.3 \mathrm{E}-2\end{array}$ & $\begin{array}{r}* \\
21 \\
1\end{array}$ \\
\hline $\begin{array}{l}2^{214} \mathrm{Bi} \\
2^{14} \mathrm{Bi}\end{array}$ & $\begin{array}{l}683.13 \\
683.30\end{array}$ & $\begin{array}{l}6.74 \text { E-4 } \\
8.0 \text { E-4 }\end{array}$ & 21 \\
\hline $\begin{array}{l}{ }^{214} \mathrm{Bi} \\
2^{214} \mathrm{Bi}\end{array}$ & $\begin{array}{l}698.23 \\
698.40\end{array}$ & $\begin{array}{l}3.34 \mathrm{E}-4 \\
7.0 \mathrm{E}-4\end{array}$ & 21 \\
\hline $\begin{array}{l}{ }^{214} \mathrm{Bi} \\
{ }^{214} \mathrm{Bi}\end{array}$ & $\begin{array}{l}703.22 \\
703.10\end{array}$ & $\begin{array}{ll}3.93 & E-3 \\
4.70 & E-3\end{array}$ & 21 \\
\hline $\begin{array}{l}{ }^{214} \mathrm{Bi} \\
{ }^{214} \mathrm{Bi}\end{array}$ & $\begin{array}{l}710.84 \\
710.8\end{array}$ & $\begin{array}{l}7.11 \mathrm{E}-4 \\
6.0 \mathrm{E}-4\end{array}$ & 21 \\
\hline $\begin{array}{l}{ }^{214} \mathrm{Bi} \\
214 \mathrm{Bi}\end{array}$ & $\begin{array}{l}719.83 \\
719.90\end{array}$ & $\begin{array}{ll}3.64 & \mathrm{E}-3 \\
3.80 & \mathrm{E}-3\end{array}$ & 21 \\
\hline${ }^{214} \mathrm{Bi}$ & $\begin{array}{l}734.30 \\
734.30\end{array}$ & $\begin{array}{l}4.99 \mathrm{E}-4 \\
3.0 \mathrm{E}-4\end{array}$ & $\begin{array}{r}* \\
21\end{array}$ \\
\hline${ }^{214} \mathrm{Bi}$ & $\begin{array}{l}752.97 \\
753.0\end{array}$ & $\begin{array}{l}1.25 \mathrm{E}-3 \\
1.1 \mathrm{E}-3\end{array}$ & 21 \\
\hline $\begin{array}{l}2^{214} \mathrm{Bi} \\
214 \mathrm{Bi} \\
2^{214} \mathrm{Bi} /{ }^{214} \mathrm{~Pb}\end{array}$ & $\begin{array}{l}768.37 \\
768.40 \\
768.40 \\
769.0\end{array}$ & $\begin{array}{l}4.97 \mathrm{E}-2 \\
8.0 \mathrm{E}-4 \\
4.8 \mathrm{E}-2 / 8.0 \mathrm{E}-4 \\
5.3 \mathrm{E}-2\end{array}$ & $\begin{array}{r}\hbar \\
21 \\
27 \\
1\end{array}$ \\
\hline $\begin{array}{l}2^{214} \mathrm{Bi} \\
2^{214} \mathrm{Bi} \\
2^{14} \mathrm{Bi}\end{array}$ & $\begin{array}{l}785.97 \\
785.95 \\
786.10 \\
787.0\end{array}$ & $\begin{array}{l}8.60 \mathrm{E}-3 \\
1.05 \mathrm{E}-2 \\
2.90 \mathrm{E}-3 \\
1.2 \mathrm{E}-2\end{array}$ & $\begin{array}{r}* \\
21 \\
27 \\
1\end{array}$ \\
\hline $\begin{array}{l}{ }^{214} \mathrm{Bi} \\
{ }^{214} \mathrm{Bi}\end{array}$ & $\begin{array}{l}806.28 \\
806.20 \\
805.0\end{array}$ & $\begin{array}{l}1.04 \mathrm{E}-2 \\
1.10 \mathrm{E}-2 \\
1.5 \mathrm{E}-2\end{array}$ & $\begin{array}{r}t \\
21 \\
1\end{array}$ \\
\hline $2^{14} \mathrm{Bi}$ & $\begin{array}{l}815.05 \\
815.0\end{array}$ & $\begin{array}{l}4.34 \mathrm{E}-4 \\
4.0 \mathrm{E}-4\end{array}$ & $\stackrel{*}{21}$ \\
\hline${ }^{214} \mathrm{Bi}$ & $\begin{array}{l}821.28 \\
821.20\end{array}$ & $\begin{array}{l}1.30 \mathrm{E}-3 \\
1.6 \mathrm{E}-3\end{array}$ & 21 \\
\hline $214_{B i}$ & $\begin{array}{l}826.13 \\
826.0\end{array}$ & $\begin{array}{l}4.59 \mathrm{E}-4 \\
1.3 \mathrm{E}-3\end{array}$ & 21 \\
\hline
\end{tabular}


Table 4.6 (Continued)

\begin{tabular}{|c|c|c|c|}
\hline Nuclide & Energy (keV) & Quantum Yield & References \\
\hline${ }^{214} \mathrm{Bi}$ & $\begin{array}{l}832.06 \\
832.0\end{array}$ & $\begin{array}{l}1.85 \mathrm{E}-4 \\
3.0 \mathrm{E}-4\end{array}$ & 21 \\
\hline${ }^{214} \mathrm{Bi}$ & $\begin{array}{l}839.10 \\
839.20\end{array}$ & $\begin{array}{l}7.96 \mathrm{E}-3 \\
5.9 \mathrm{E}-3\end{array}$ & 21 \\
\hline${ }^{214} \mathrm{Bi}$ & $\begin{array}{l}934.09 \\
934.0 \\
935.0\end{array}$ & 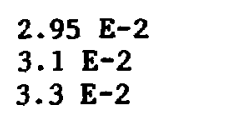 & $\begin{array}{r}\star \\
21 \\
1\end{array}$ \\
\hline${ }^{214} \mathrm{Bi}$ & $\begin{array}{l}964.10 \\
964.10\end{array}$ & $\begin{array}{l}3.23 \mathrm{E}-3 \\
3.7 \mathrm{E}-3\end{array}$ & $\begin{array}{r}* \\
21\end{array}$ \\
\hline${ }^{214} \mathrm{Bi}$ & $\begin{array}{l}1032.24 \\
1032.5\end{array}$ & $\begin{array}{l}1.18 \mathrm{E}-3 \\
7.0 \mathrm{E}-4\end{array}$ & 21 \\
\hline $214 \mathrm{Bi}$ & $\begin{array}{l}1051.92 \\
1052.00\end{array}$ & $\begin{array}{l}2.82 \mathrm{E}-3 \\
3.3 \mathrm{E}-3\end{array}$ & 21 \\
\hline${ }^{214} \mathrm{Bi}$ & $\begin{array}{l}1069.95 \\
1070.00\end{array}$ & $\begin{array}{ll}1.98 & E-3 \\
2.60 & E-3\end{array}$ & 21 \\
\hline${ }^{214} \mathrm{Bi}$ & $\begin{array}{l}1103.92 \\
1104.0\end{array}$ & $\begin{array}{l}1.39 \mathrm{E}-3 \\
1.6 \mathrm{E}-3\end{array}$ & 21 \\
\hline $214_{B i}$ & $\begin{array}{l}1120.21 \\
1120.40 \\
1120.0\end{array}$ & $\begin{array}{l}1.46 \mathrm{E}-1 \\
1.50 \mathrm{E}-1 \\
1.6 \mathrm{E}-1\end{array}$ & $\begin{array}{r}* \\
21 \\
1\end{array}$ \\
\hline $214 \mathrm{Bi}$ & $\begin{array}{l}1133.76 \\
1133.80\end{array}$ & $\begin{array}{ll}2.46 & \mathrm{E}-3 \\
2.50 & \mathrm{E}-3\end{array}$ & 21 \\
\hline${ }^{214} \mathrm{Bi}$ & $\begin{array}{l}1155.12 \\
1155.30 \\
1155.0\end{array}$ & $\begin{array}{ll}1.60 & \mathrm{E}-2 \\
1.70 & \mathrm{E}-2 \\
1.80 & \mathrm{E}-2\end{array}$ & $\begin{array}{r}21 \\
1\end{array}$ \\
\hline $214 \mathrm{Bi}$ & $\begin{array}{l}1173.08 \\
1172.90\end{array}$ & $\begin{array}{l}7.21 \mathrm{E}-4 \\
3.0 \mathrm{E}-4\end{array}$ & 21 \\
\hline${ }^{214} \mathrm{Bi}$ & $\begin{array}{l}1207.62 \\
1207.80\end{array}$ & $\begin{array}{ll}4.30 & E-3 \\
4.70 & E-3\end{array}$ & 21 \\
\hline${ }^{214} \mathrm{Bi}$ & $\begin{array}{l}1238.07 \\
1238.2\end{array}$ & $\begin{array}{l}5.98 \mathrm{E}-2 \\
6.1 \mathrm{E}-2\end{array}$ & $\begin{array}{r}* \\
21\end{array}$ \\
\hline${ }^{214} \mathrm{Bi}$ & $\begin{array}{l}1280.95 \\
1281.10\end{array}$ & $\begin{array}{ll}1.33 & \mathrm{E}-2 \\
1.50 \mathrm{E}-2\end{array}$ & 21 \\
\hline $214 \mathrm{Bi}$ & $\begin{array}{l}1303.77 \\
1303.80\end{array}$ & $\begin{array}{ll}1.04 & \mathrm{E}-3 \\
1.10 & \mathrm{E}-3\end{array}$ & 21 \\
\hline${ }^{214} \mathrm{Bi}$ & $\begin{array}{l}1377.82 \\
1377.70\end{array}$ & $\begin{array}{ll}4.91 & E-2 \\
4.30 & E-2\end{array}$ & $\begin{array}{r}* \\
21\end{array}$ \\
\hline${ }^{214} \mathrm{Bi}$ & $\begin{array}{l}1385.49 \\
1385.40\end{array}$ & $\begin{array}{l}7.76 \mathrm{E}-3 \\
8.0 \mathrm{E}-3\end{array}$ & $\begin{array}{r}* \\
21\end{array}$ \\
\hline $\begin{array}{l}214 \mathrm{Po} \\
214 \mathrm{Po}\end{array}$ & $\begin{array}{l}799.48 \\
799.00\end{array}$ & $\begin{array}{l}4.0 \mathrm{E}-4 \\
1.4 \mathrm{E}-4\end{array}$ & $\begin{array}{r}* \\
27\end{array}$ \\
\hline
\end{tabular}


Table 4.6 (Continued)

\begin{tabular}{lllr}
\hline Nuclide & Energy (keV) & Quantum Yield & References \\
\hline $210 \mathrm{~Pb}$ & 46.50 & $4.10 \mathrm{E}-2$ & $\star$ \\
& 46.52 & $7.30 \mathrm{E}-2$ & 21 \\
& 46.52 & $4.10 \mathrm{E}-2$ & 27 \\
& 47.0 & $4.10 \mathrm{E}-2$ & 1 \\
\hline
\end{tabular}


Table 4.7. Energy and Quantua Yield of Nuclides in the Actiniun Series: Comparison of Values Measured in This Study with

Those Previously Reported

\begin{tabular}{|c|c|c|c|}
\hline Nuclide & Energy (keV) & Quantum Yield & References \\
\hline $235 \mathrm{U}$ & $\begin{array}{l}109.15 \\
110.0 \\
109.145 \\
109.12\end{array}$ & $1.55 \mathrm{E}-2$ & $\begin{array}{r}* \\
20 \\
29 \\
15\end{array}$ \\
\hline $235 U$ & $\begin{array}{l}115.20 \\
115.20\end{array}$ & $1.18 \mathrm{E}-3$ & $\begin{array}{r}* \\
15\end{array}$ \\
\hline $235_{\mathrm{U}}$ & $\begin{array}{l}140.76 \\
140.75 \\
140.758 \\
140.75\end{array}$ & $\begin{array}{ll}1.74 & E-3 \\
2.08 & E-3\end{array}$ & $\begin{array}{r}* \\
27 \\
29 \\
15\end{array}$ \\
\hline $235 \mathrm{U}$ & $\begin{array}{l}143.82 \\
143.78 \\
143.753 \\
143.0 \\
143.77\end{array}$ & $\begin{array}{l}1.05 \mathrm{E}-1 \\
1.1 \mathrm{E}-1 \\
1.07 \mathrm{E}-1\end{array}$ & $\begin{array}{r}* \\
15 \\
29 \\
1 \\
27\end{array}$ \\
\hline${ }^{235} U$ & $\begin{array}{l}163.35 \\
163.37 \\
163.349 \\
163.363\end{array}$ & $\begin{array}{l}4.77 \mathrm{E}-2 \\
4.85 \mathrm{E}-2\end{array}$ & $\begin{array}{l}* \\
27 \\
29 \\
15\end{array}$ \\
\hline $235 \mathrm{U}$ & $\begin{array}{l}185.72 \\
185.712 \\
185.72 \\
185.718 \\
185.0\end{array}$ & $\begin{array}{l}5.61 \mathrm{E}-1 \\
5.61 \mathrm{E}-1 \\
5.4 \mathrm{E}-1\end{array}$ & $\begin{array}{r}* \\
29 \\
27 \\
15 \\
1\end{array}$ \\
\hline $235 \mathrm{U}$ & $\begin{array}{l}195.85 \\
194.938 \\
194.94 \\
194.94\end{array}$ & $\begin{array}{l}6.73 \mathrm{E}-3 \\
6.15 \mathrm{E}-3\end{array}$ & $\begin{array}{r}亡 \\
29 \\
27 \\
15\end{array}$ \\
\hline${ }^{235} U$ & $\begin{array}{l}202.04 \\
202.105 \\
202.10 \\
202.13\end{array}$ & $\begin{array}{l}8.64 \mathrm{E}-3 \\
1.07 \mathrm{E}-2\end{array}$ & $\begin{array}{r}* \\
29 \\
27 \\
15\end{array}$ \\
\hline $235 \mathrm{U}$ & $\begin{array}{l}205.27 \\
205.312 \\
205.33 \\
205.311\end{array}$ & $\begin{array}{l}4.87 \mathrm{E}-2 \\
4.87 \mathrm{E}-2\end{array}$ & $\begin{array}{l}* \\
29 \\
27 \\
15\end{array}$ \\
\hline
\end{tabular}

\footnotetext{
$\overline{a_{\text {The }} \text { values measured }}$ in this investigation are followed by an asterisk in the reference column.
} 
Table 4.7 (Continued)

\begin{tabular}{|c|c|c|c|c|}
\hline Nuclide & Energy (keV) & & Quantum Yield & References \\
\hline $235_{\mathrm{U}}$ & $\begin{array}{l}221.38 \\
221.397 \\
221.375\end{array}$ & 1.23 & $\mathbf{E}-3$ & $\begin{array}{r}* \\
29 \\
27\end{array}$ \\
\hline $235_{U}$ & $\begin{array}{l}240.93 \\
240.93 \\
240.95 \\
240.93\end{array}$ & $\begin{array}{l}7.85 \\
6.40\end{array}$ & $\begin{array}{l}E-4 \\
E-4\end{array}$ & $\begin{array}{l}\div \\
27 \\
29 \\
15\end{array}$ \\
\hline${ }^{235} \mathrm{U}$ & $\begin{array}{l}246.83 \\
246.88 \\
246.59 \\
246.83\end{array}$ & $\begin{array}{l}6.17 \\
5.20\end{array}$ & $\begin{array}{l}\text { E-4 } \\
E-4\end{array}$ & $\begin{array}{r}* \\
27 \\
29 \\
15\end{array}$ \\
\hline${ }^{231} \mathrm{Th}$ & $\begin{array}{l}163.64 \\
163.16 \\
163.33\end{array}$ & $\begin{array}{l}1.09 \\
1.39\end{array}$ & $\begin{array}{l}\text { E-2 } \\
\text { E-3 }\end{array}$ & $\begin{array}{r}\hbar \\
27 \\
20\end{array}$ \\
\hline${ }^{231} \mathrm{~Pa}$ & $\begin{array}{l}302.50 \\
302.52 \\
302.0\end{array}$ & $\begin{array}{l}3.62 \\
7.02\end{array}$ & $\begin{array}{l}E-2 \\
E-4\end{array}$ & $\begin{array}{r}\% \\
27 \\
20\end{array}$ \\
\hline${ }^{227} \mathrm{Th}$ & $\begin{array}{l}49.95 \\
50.20 \\
50.0 \\
49.9 / 50.1\end{array}$ & $\begin{array}{l}7.67 \\
8.59 \\
4.4 \mathrm{E}\end{array}$ & $\begin{array}{l}E-2 \\
E-2 \\
E-2\end{array}$ & $\begin{array}{r}* \\
27 \\
20 \\
7\end{array}$ \\
\hline${ }^{227} \mathrm{Th}$ & $\begin{array}{l}113.08 \\
113.1 \\
113.1\end{array}$ & $\begin{array}{l}6.60 \\
7.7 \mathrm{E} \\
5.33\end{array}$ & $\begin{array}{c}E-3 \\
E-3 \\
E-3\end{array}$ & $\begin{array}{r}\frac{1}{n} \\
7 \\
27\end{array}$ \\
\hline $227_{\mathrm{Th}}$ & $\begin{array}{l}206.10 \\
206.0 \\
206.1 / 206.4\end{array}$ & $\begin{array}{l}3.59 \\
2.20 \\
2.57\end{array}$ & $\begin{array}{l}E-3 \\
E-3 \\
E-3 / 3.93 \quad E-5\end{array}$ & $\begin{array}{r}* \\
7 \\
27\end{array}$ \\
\hline $227_{\mathrm{Th}}$ & $\begin{array}{l}210.72 \\
210.60 \\
210.60\end{array}$ & $\begin{array}{l}1.10 \\
9.90 \\
1.24\end{array}$ & $\begin{array}{l}E-2 \\
E-3 \\
E-2\end{array}$ & $\begin{array}{r}7 \\
7 \\
27\end{array}$ \\
\hline${ }^{227} \mathrm{Th}$ & $\begin{array}{l}235.90 \\
236.0 \\
236.00\end{array}$ & $\begin{array}{l}1.10 \\
1.035 \\
1.14\end{array}$ & $\begin{array}{l}E-1 \\
5 E-1 \\
E-1\end{array}$ & $\begin{array}{r}* \\
7 \\
27\end{array}$ \\
\hline${ }^{227} \mathrm{Th}$ & $\begin{array}{l}250.07 \\
250.1 \\
249.6 / 250.2 / 250.4 \\
250.0\end{array}$ & $\begin{array}{l}3.30 \\
4.90 \\
6.91\end{array}$ & $\begin{array}{l}E-3 \\
E-3 \\
E-5 / 2.76 \quad E-3 / 6.91 \quad E-4\end{array}$ & $\begin{array}{r}* \\
7 \\
27 \\
15\end{array}$ \\
\hline${ }^{227} \mathrm{Th}$ & $\begin{array}{l}256.18 \\
256.20 \\
256.20\end{array}$ & $\begin{array}{l}7.75 \\
6.03 \\
6.22\end{array}$ & $\begin{array}{l}\text { E-2 } \\
\text { E-2 } \\
\text { E-2 }\end{array}$ & $\begin{array}{r}\star \\
7 \\
27\end{array}$ \\
\hline
\end{tabular}


Table 4.7 (Continued)

\begin{tabular}{|c|c|c|c|}
\hline Nuclide & Energy (keV) & Quantum Yield & References \\
\hline \multirow[t]{2}{*}{$227 \mathrm{Th}$} & $\begin{array}{l}281.09 \\
281.3 \\
281.4 \\
281.0\end{array}$ & $\begin{array}{ll}1.32 & \mathrm{E}-3 \\
1.70 & \mathrm{E}-3 \\
1.48 & \mathrm{E}-3\end{array}$ & $\begin{array}{r}* \\
7 \\
27 \\
20\end{array}$ \\
\hline & $\begin{array}{l}286.12 \\
286.10 \\
286.20\end{array}$ & $\begin{array}{ll}6.90 & \mathrm{E}-3 \\
1.50 & \mathrm{E}-2 \\
1.63 & \mathrm{E}-2\end{array}$ & $\begin{array}{r}* \\
7 \\
27\end{array}$ \\
\hline${ }^{227} \mathrm{Th}$ & $\begin{array}{l}299.93 \\
299.8\end{array}$ & $\begin{array}{ll}3.89 & E-3 \\
1.86 & E-2\end{array}$ & $\star$ \\
\hline${ }^{227} \mathrm{Th}$ & $\begin{array}{l}304.55 \\
304.40 \\
304.40\end{array}$ & $\begin{array}{ll}9.35 & \mathrm{E}-3 \\
1.33 & \mathrm{E}-2 \\
8.90 & \mathrm{E}-3\end{array}$ & $\begin{array}{r}* \\
27 \\
7\end{array}$ \\
\hline $227^{T h}$ & $\begin{array}{l}314.34 \\
314.8 \\
314.8\end{array}$ & 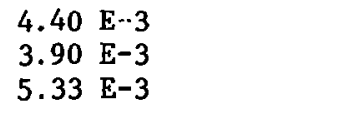 & $\begin{array}{r}* \\
7 \\
27\end{array}$ \\
\hline $227 \mathrm{Th}$ & $\begin{array}{l}329.80 \\
329.70 \\
329.70\end{array}$ & $\begin{array}{ll}3.45 & \mathrm{E}-2 \\
2.37 & \mathrm{E}-2 \\
2.86 & \mathrm{E}-2\end{array}$ & $\begin{array}{r}* \\
7 \\
27\end{array}$ \\
\hline${ }^{227} \mathrm{Th}$ & $\begin{array}{l}333.97 \\
334.20 \\
334.40 \\
334.02\end{array}$ & $\begin{array}{ll}5.11 & E-4 \\
8.65 & E-3 \\
1.14 & E-2\end{array}$ & $\begin{array}{r}* \\
7 \\
27 \\
15\end{array}$ \\
\hline${ }^{223} \mathrm{Fr}$ & $\begin{array}{l}49.8 \\
49.8\end{array}$ & $\begin{array}{ll}4.63 & \mathrm{E}-2 \\
5.20 & \mathrm{E}-3\end{array}$ & $\begin{array}{r}* \\
27\end{array}$ \\
\hline${ }^{223} \mathrm{Ra}$ & $\begin{array}{l}122.75 \\
122.30\end{array}$ & $\begin{array}{ll}1.00 & \mathrm{E}-2 \\
1.33 & \mathrm{E}-2\end{array}$ & 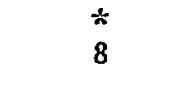 \\
\hline${ }^{223} \mathrm{Ra}$ & $\begin{array}{l}144.24 \\
144.19\end{array}$ & $\begin{array}{ll}5.86 & \mathrm{E}-2 \\
3.13 & \mathrm{E}-2\end{array}$ & $\frac{t}{x}$ \\
\hline $223_{\mathrm{Ra}}$ & $\begin{array}{l}154.25 \\
154.18\end{array}$ & $\begin{array}{ll}7.22 & \text { E-2 } \\
5.23 & \text { E-2 }\end{array}$ & $\stackrel{1}{8}$ \\
\hline${ }^{223} \mathrm{Ra}$ & $\begin{array}{l}158.39 \\
158.62\end{array}$ & $\begin{array}{ll}6.05 & \mathrm{E}-3 \\
7.60 & \mathrm{E}-3\end{array}$ & $\stackrel{*}{8}$ \\
\hline${ }^{223} \mathrm{Ra}$ & $\begin{array}{l}269.41 \\
269.41\end{array}$ & $\begin{array}{ll}1.50 & \mathrm{E}-1 \\
1.36 & \mathrm{E}-1\end{array}$ & $\ddot{x}$ \\
\hline${ }^{223} \mathrm{Ra}$ & $\begin{array}{l}323.84 \\
323.88\end{array}$ & $\begin{array}{ll}3.69 & \mathrm{E}-2 \\
3.60 & \mathrm{E}-2\end{array}$ & $\frac{t}{8}$ \\
\hline${ }^{223} \mathrm{Ra}$ & $\begin{array}{l}333.84 \\
333.80\end{array}$ & $\begin{array}{ll}4.90 & E-3 \\
1.24 & E-3\end{array}$ & 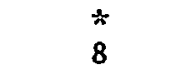 \\
\hline${ }^{223} \mathrm{Ra}$ & $\begin{array}{l}338.29 \\
338.30\end{array}$ & $\begin{array}{ll}1.29 & \mathrm{E}-2 \\
2.59 & \mathrm{E}-2\end{array}$ & $\hat{*}$ \\
\hline
\end{tabular}


Table 4.7 (Continued)

\begin{tabular}{|c|c|c|c|}
\hline Nuclide & Energy (keV) & Quantum Yield & References \\
\hline${ }^{223} \mathrm{Ra}$ & $\begin{array}{l}371.80 \\
371.50\end{array}$ & $\begin{array}{l}4.40 \mathrm{E}-3 \\
5.40 \mathrm{E}-3\end{array}$ & $\begin{array}{l}* \\
8\end{array}$ \\
\hline${ }^{223} \mathrm{Ra}$ & $\begin{array}{l}444.92 \\
444.92\end{array}$ & $\begin{array}{ll}9.90 & \mathrm{E}-2 \\
1.27 & \mathrm{E}-2\end{array}$ & $\ddot{8}$ \\
\hline $219_{\mathrm{Rn}}$ & $\begin{array}{l}130.75 \\
130.70\end{array}$ & $\begin{array}{l}9.66 \mathrm{E}-3 \\
1.04 \mathrm{E}-3\end{array}$ & $\ddot{*}$ \\
\hline${ }^{219} \mathrm{Rn}$ & $\begin{array}{l}271.20 \\
271.20\end{array}$ & $\begin{array}{l}1.20 \mathrm{E}-1 \\
9.93 \mathrm{E}-2\end{array}$ & $\frac{1}{9}$ \\
\hline${ }^{219} \mathrm{Rn}$ & $\begin{array}{l}401.84 \\
401.80\end{array}$ & $\begin{array}{ll}7.98 & \mathrm{E}-2 \\
6.48 & \mathrm{E}-2\end{array}$ & $\begin{array}{l}+1 \\
9\end{array}$ \\
\hline${ }^{211} \mathrm{~Pb}$ & $\begin{array}{l}404.89 \\
404.80\end{array}$ & $\begin{array}{l}7.72 \text { E-2 } \\
3.94 \text { E-2 }\end{array}$ & $\stackrel{*}{27}$ \\
\hline \multirow[t]{2}{*}{${ }^{211} \mathrm{~Pb}$} & $\begin{array}{l}426.90 \\
426.90\end{array}$ & $\begin{array}{l}1.74 \text { E-2 } \\
1.82 \mathrm{E}-2\end{array}$ & $\begin{array}{r}* \\
27\end{array}$ \\
\hline & $\begin{array}{l}832.06 \\
831.80\end{array}$ & $\begin{array}{ll}3.27 & \mathrm{E}-2 \\
3.21 & \mathrm{E}-2\end{array}$ & $\begin{array}{r}* \\
27\end{array}$ \\
\hline $211_{B i}$ & $\begin{array}{l}351.89 \\
351.10\end{array}$ & $\begin{array}{l}1.33 \mathrm{E}-1 \\
1.33 \mathrm{E}-1\end{array}$ & $\begin{array}{r}* \\
27\end{array}$ \\
\hline
\end{tabular}


Table 4.8. Energy and Quantum Yield of Nuclides in the Thorium Series: Comparison of Values Measured in this Study with Those Previously Reported

\begin{tabular}{|c|c|c|c|}
\hline Nuclide & Energy (keV) & Quantum Yield & References \\
\hline${ }^{228} \mathrm{Th}$ & $\begin{array}{l}131.51 \\
132.0 \\
131.62 \\
132.0\end{array}$ & $\begin{array}{l}1.475 \mathrm{E}-3 \\
2.60 \mathrm{E}-3\end{array}$ & $\begin{array}{r}* \\
20 \\
15 \\
27\end{array}$ \\
\hline${ }^{228} \mathrm{Th}$ & $\begin{array}{l}215.94 \\
214.0 \\
215.94 \\
217.0\end{array}$ & $\begin{array}{l}2.71 \mathrm{E}-3 \\
2.70 \mathrm{E}-3\end{array}$ & $\begin{array}{r}\star \\
20 \\
15 \\
27\end{array}$ \\
\hline $212 \mathrm{~Pb}$ & $\begin{array}{l}176.49 \\
176.63 \\
176.84\end{array}$ & $\begin{array}{ll}2.75 & E-4 \\
5.22 & E-4\end{array}$ & $\begin{array}{r}* \\
27 \\
15\end{array}$ \\
\hline $212 \mathrm{~Pb}$ & $\begin{array}{l}238.62 \\
238.62 \\
238.63\end{array}$ & $\begin{array}{l}4.69 \mathrm{E}-1 \\
4.46 \mathrm{E}-1\end{array}$ & $\begin{array}{c}* \\
15 / 20 \\
27\end{array}$ \\
\hline${ }^{212} \mathrm{~Pb}$ & $\begin{array}{l}300.03 \\
300.1 \\
300.08 \\
300.11\end{array}$ & $\begin{array}{l}2.87 \mathrm{E}-2 \\
3.42 \mathrm{E}-2\end{array}$ & $\begin{array}{r}* \\
20 \\
15 \\
27\end{array}$ \\
\hline $212 \mathrm{~Pb}$ & $\begin{array}{l}415.32 \\
415.2 \\
415.2\end{array}$ & $\begin{array}{l}4.47 \mathrm{E}-4 \\
1.80 \mathrm{E}-4\end{array}$ & $\begin{array}{r}2 \\
20 \\
27\end{array}$ \\
\hline $212 \mathrm{Bi}$ & $\begin{array}{l}39.90 \\
39.85 \\
39.87\end{array}$ & $\begin{array}{l}8.64 \mathrm{E}-3 \\
1.10 \mathrm{E}-2\end{array}$ & $\begin{array}{r}* \\
20 \\
27\end{array}$ \\
\hline${ }^{212} \mathrm{Bi}$ & $\begin{array}{l}153.99 \\
154.0\end{array}$ & $\begin{array}{ll}7.63 & \mathrm{E}-3 \\
1.01 & \mathrm{E}-4\end{array}$ & $\begin{array}{r}* \\
27\end{array}$ \\
\hline $212 \mathrm{Bi}$ & $\begin{array}{l}288.10 \\
288.07\end{array}$ & $\begin{array}{ll}3.55 & E-3 \\
3.42 & E-3\end{array}$ & $\begin{array}{r}* \\
27\end{array}$ \\
\hline${ }^{212} \mathrm{Bi}$ & $\begin{array}{l}295.10 \\
294.0 \\
295.19 \\
295.10\end{array}$ & $\begin{array}{l}4.95 E-3 \\
2.41 E-4\end{array}$ & $\begin{array}{r}* \\
20 \\
15 \\
27\end{array}$ \\
\hline $\begin{array}{l}{ }^{212} \mathrm{Bi} \\
212 \mathrm{Bi}\end{array}$ & $\begin{array}{l}327.97 \\
328.0 \\
327.98 \\
327.96\end{array}$ & $1.40 \mathrm{E}-3$ & $\begin{array}{r}* \\
20 \\
15 \\
27\end{array}$ \\
\hline
\end{tabular}

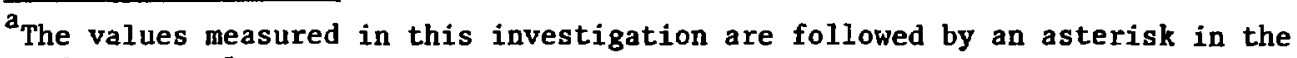
reference column. 
Table 4.8 (Continued)

\begin{tabular}{|c|c|c|c|}
\hline Nuclide & Energy (keV) & Quantum Yield & References \\
\hline $212 \mathrm{Bi}$ & $\begin{array}{l}452.86 \\
452.91 \\
452.0 \\
452.83\end{array}$ & $\begin{array}{l}3.71 E-3 \\
3.74 E-3\end{array}$ & $\begin{array}{r}: \\
15 \\
20 \\
27\end{array}$ \\
\hline${ }^{212} \mathrm{Bi}$ & $\begin{array}{l}473.53 \\
472.0 \\
473.50\end{array}$ & $\begin{array}{l}2.00 \mathrm{E}-4 \\
4.68 \mathrm{E}-4\end{array}$ & $\begin{array}{r}* \\
20 \\
27\end{array}$ \\
\hline${ }^{212} \mathrm{Bi}$ & $\begin{array}{l}727.33 \\
727.0 \\
727.27\end{array}$ & $\begin{array}{l}6.74 \mathrm{E}-2 \\
7.1 \mathrm{E}-2 \\
6.66 \mathrm{E}-2\end{array}$ & $\begin{array}{r}* \\
1 \\
27\end{array}$ \\
\hline $212 \mathrm{Bi}$ & $\begin{array}{l}893.48 \\
893.30 \\
893.35\end{array}$ & $\begin{array}{l}3.20 \mathrm{E}-3 \\
3.67 \mathrm{E}-3\end{array}$ & $\begin{array}{r}* \\
15 \\
27\end{array}$ \\
\hline${ }^{212} \mathrm{Bi}$ & $\begin{array}{l}952.29 \\
952.10\end{array}$ & $\begin{array}{l}1.49 \mathrm{E}-3 \\
1.76 \mathrm{E}-3\end{array}$ & 27 \\
\hline $212 \mathrm{Bi}$ & $\begin{array}{l}1078.78 \\
1078.73 \\
1078.80\end{array}$ & $\begin{array}{l}5.33 \mathrm{E}-3 \\
5.36 \mathrm{E}-3\end{array}$ & $\begin{array}{r}* \\
15 \\
27\end{array}$ \\
\hline${ }^{208} \mathrm{Tl}$ & $\begin{array}{l}233.29 \\
233.50 \\
233.0\end{array}$ & $\begin{array}{l}6.18 \mathrm{E}-4 \\
1.19 \mathrm{E}-3\end{array}$ & $\begin{array}{r}* \\
27 \\
20\end{array}$ \\
\hline${ }^{208} \mathrm{TI}$ & $\begin{array}{l}252.66 \\
252.0 \\
252.60\end{array}$ & $\begin{array}{l}1.96 \mathrm{E}-3 \\
2.52 \mathrm{E}-3\end{array}$ & $\begin{array}{r}* \\
20 \\
27\end{array}$ \\
\hline${ }^{208} \mathrm{~T} 1$ & $\begin{array}{l}277.33 \\
277.33 \\
277.36 \\
277.36\end{array}$ & $\begin{array}{l}1.94 \mathrm{E}-2 \\
2.34 \mathrm{E}-2\end{array}$ & $\begin{array}{l}* \\
20 \\
15 \\
27\end{array}$ \\
\hline${ }^{208} \mathrm{Tl}$ & $\begin{array}{l}510.74 \\
510.72 \\
510.70 \\
510.72\end{array}$ & $\begin{array}{l}7.02 \mathrm{E}-2 \\
8.10 \mathrm{E}-2\end{array}$ & $\begin{array}{r}* \\
20 \\
15 \\
27\end{array}$ \\
\hline${ }^{208} \mathrm{~T} 1$ & $\begin{array}{l}583.21 \\
583.14\end{array}$ & $\begin{array}{l}2.77 \mathrm{E}-1 \\
3.10 \mathrm{E}-1\end{array}$ & $\begin{array}{r}* \\
27\end{array}$ \\
\hline${ }^{208} \mathrm{~T} 1$ & $\begin{array}{l}763.42 \\
763.32 \\
763.2 \\
763.30\end{array}$ & $\begin{array}{l}5.34 \mathrm{E}-3 \\
6.05 \mathrm{E}-3\end{array}$ & $\begin{array}{l}* \\
15 \\
20 \\
27\end{array}$ \\
\hline${ }^{208} \mathrm{Tl}$ & $\begin{array}{l}860.65 \\
860.53 \\
860.0 \\
860.47\end{array}$ & $4.528 \mathrm{E}-2$ & $\begin{array}{r}* \\
15 \\
20 \\
27\end{array}$ \\
\hline
\end{tabular}


Table 4.8 (Continued)

\begin{tabular}{|c|c|c|c|}
\hline Nuclide & Energy (keV) & Quantum Yield & References \\
\hline${ }^{208} \mathrm{~T} 1$ & $\begin{array}{l}982.40 \\
982.80\end{array}$ & $\begin{array}{l}9.24 \mathrm{E}-4 \\
7.20 \mathrm{E}-4\end{array}$ & $\stackrel{2}{*}$ \\
\hline${ }^{208} \mathrm{Tl}$ & $\begin{array}{l}1004.59 \\
1004.00\end{array}$ & $\begin{array}{l}2.01 \mathrm{E}-3 \\
3.60 \mathrm{E}-3\end{array}$ & 27 \\
\hline${ }^{224} \mathrm{Ra}$ & $\begin{array}{l}240.98 \\
240.98 \\
240.98\end{array}$ & $\begin{array}{l}4.70 \mathrm{E}-2 \\
3.70 \mathrm{E}-2\end{array}$ & $\begin{array}{l}\not \\
20 \\
27\end{array}$ \\
\hline${ }^{228} \mathrm{AC}$ & $\begin{array}{l}129.07 \\
128.90 \\
129.0 \\
129.10\end{array}$ & $\begin{array}{l}1.83 \mathrm{E}-2 \\
3.03 \mathrm{E}-2\end{array}$ & $\begin{array}{l}* \\
15 \\
20 \\
27\end{array}$ \\
\hline${ }^{228} A C$ & $\begin{array}{l}140.86 \\
141.00\end{array}$ & $\begin{array}{l}3.80 \mathrm{E}-4 \\
5.10 \mathrm{E}-4\end{array}$ & 27 \\
\hline${ }^{228} \mathrm{AC}$ & $\begin{array}{l}145.85 \\
145.90\end{array}$ & $\begin{array}{ll}1.12 & \mathrm{E}-3 \\
2.28 & \mathrm{E}-3\end{array}$ & $\begin{array}{r}* \\
27\end{array}$ \\
\hline $228 \mathrm{Ac}$ & $\begin{array}{l}184.60 \\
184.0 \\
184.60\end{array}$ & $\begin{array}{l}1.09 \mathrm{E}-3 \\
1.05 \mathrm{E}-3\end{array}$ & $\begin{array}{r}* \\
20 \\
27\end{array}$ \\
\hline${ }^{228} \mathrm{AC}$ & $\begin{array}{l}191.29 \\
191.50\end{array}$ & $\begin{array}{l}9.66 \mathrm{E}-4 \\
1.26 \mathrm{E}-3\end{array}$ & 27 \\
\hline $228 \mathrm{AC}$ & $\begin{array}{l}199.41 \\
199.50\end{array}$ & $\begin{array}{ll}2.47 & E-3 \\
3.63 & E-3\end{array}$ & $\begin{array}{r}* \\
27\end{array}$ \\
\hline $228 \mathrm{AC}$ & $\begin{array}{l}204.11 \\
204.10\end{array}$ & $\begin{array}{ll}9.08 & E-4 \\
1.77 & E-3\end{array}$ & $\begin{array}{r}* \\
27\end{array}$ \\
\hline${ }^{228} \mathrm{Ac}$ & $\begin{array}{l}209.24 \\
209.40\end{array}$ & $\begin{array}{ll}3.73 & \mathrm{E}-2 \\
4.71 & \mathrm{E}-2\end{array}$ & 27 \\
\hline $228_{\mathrm{AC}}$ & $\begin{array}{l}270.22 \\
270.30 \\
270.21\end{array}$ & $\begin{array}{ll}3.30 & E-2 \\
3.90 & E-2\end{array}$ & $\begin{array}{r}* \\
27 \\
15\end{array}$ \\
\hline $228 \mathrm{Ac}$ & $\begin{array}{l}278.84 \\
279.00\end{array}$ & $\begin{array}{ll}1.46 & \mathrm{E}-3 \\
2.40 & \mathrm{E}-3\end{array}$ & 27 \\
\hline${ }^{228} \mathrm{AC}$ & $\begin{array}{l}321.62 \\
321.70\end{array}$ & $\begin{array}{ll}1.78 & \mathrm{E}-3 \\
2.61 & \mathrm{E}-3\end{array}$ & 27 \\
\hline${ }^{228} \mathrm{AC}$ & $\begin{array}{l}328.00 \\
328.0\end{array}$ & $\begin{array}{ll}2.89 & \mathrm{E}-2 \\
3.48 & \mathrm{E}-2\end{array}$ & $\begin{array}{r}* \\
27\end{array}$ \\
\hline $228 \mathrm{AC}$ & $\begin{array}{l}332.37 \\
332.40\end{array}$ & $\begin{array}{ll}3.39 & \mathrm{E}-3 \\
4.89 & \mathrm{E}-3\end{array}$ & $\stackrel{*}{27}$ \\
\hline $228_{\mathrm{AC}}$ & $\begin{array}{l}338.29 \\
338.296 \\
338.40\end{array}$ & $\begin{array}{l}1.22 \mathrm{E}-1 \\
1.24 \mathrm{E}-1\end{array}$ & $\begin{array}{r}* \\
15 \\
27\end{array}$ \\
\hline
\end{tabular}


Table 4.8 (Continued)

\begin{tabular}{|c|c|c|c|}
\hline Nuclide & Energy (keV) & Quantum Yield & References \\
\hline${ }^{228} \mathrm{AC}$ & $\begin{array}{l}340.86 \\
340.90\end{array}$ & $\begin{array}{ll}3.76 & E-3 \\
4.35 & E-3\end{array}$ & $\begin{array}{r}* \\
27\end{array}$ \\
\hline${ }^{228} \mathrm{AC}$ & $\begin{array}{l}377.37 \\
377.80\end{array}$ & $\begin{array}{ll}1.83 & E-3 \\
3.30 & E-4\end{array}$ & 27 \\
\hline${ }^{228} \mathrm{AC}$ & $\begin{array}{l}409.45 \\
409.44 \\
409.40\end{array}$ & $\begin{array}{l}1.80 \mathrm{E}-2 \\
2.31 \mathrm{E}-2\end{array}$ & $\begin{array}{r}* \\
15 \\
27\end{array}$ \\
\hline $228_{A C}$ & $\begin{array}{l}416.10 \\
416.10\end{array}$ & $\begin{array}{ll}4.47 & E-4 \\
1.80 & E-4\end{array}$ & $\begin{array}{r}* \\
27\end{array}$ \\
\hline${ }^{228} \mathrm{AC}$ & $\begin{array}{l}440.50 \\
440.30\end{array}$ & $\begin{array}{ll}9.88 & E-4 \\
1.50 & E-3\end{array}$ & $\begin{array}{r}* \\
27\end{array}$ \\
\hline $22^{8} \mathrm{AC}$ & $\begin{array}{l}462.99 \\
463.00 \\
463.00\end{array}$ & $\begin{array}{l}4.21 \mathrm{E}-2 \\
4.80 \mathrm{E}-2\end{array}$ & $\begin{array}{r}* \\
15\end{array}$ \\
\hline${ }^{228} \mathrm{AC}$ & $\begin{array}{l}474.60 \\
474.60\end{array}$ & $\begin{array}{l}3.00 E-4 \\
3.00 E-4\end{array}$ & $\begin{array}{r}* \\
27\end{array}$ \\
\hline${ }^{228} \mathrm{AC}$ & $\begin{array}{l}478.26 \\
478.20\end{array}$ & $\begin{array}{ll}1.42 & E-3 \\
2.49 & E-3\end{array}$ & $\begin{array}{r}* \\
27\end{array}$ \\
\hline $228 \mathrm{AC}$ & $\begin{array}{l}503.86 \\
503.70\end{array}$ & $\begin{array}{ll}1.22 & \mathrm{E}-3 \\
2.22 & \mathrm{E}-3\end{array}$ & $\begin{array}{r}* \\
27\end{array}$ \\
\hline${ }^{228} \mathrm{AC}$ & $\begin{array}{l}523.26 \\
523.00\end{array}$ & $\begin{array}{ll}7.51 & E-4 \\
1.26 & E-3\end{array}$ & $\begin{array}{r}* \\
27\end{array}$ \\
\hline${ }^{228} \mathrm{AC}$ & $\begin{array}{l}546.40 \\
546.30\end{array}$ & $\begin{array}{ll}1.52 & E-3 \\
2.28 & E-3\end{array}$ & $\ddot{27}$ \\
\hline${ }^{228} \mathrm{AC}$ & $\begin{array}{l}562.52 \\
562.30\end{array}$ & $\begin{array}{ll}9.02 & \mathrm{E}-3 \\
1.02 \mathrm{E}-2\end{array}$ & 27 \\
\hline $228_{A C}$ & $\begin{array}{l}571.42 \\
570.70 / 572.10\end{array}$ & 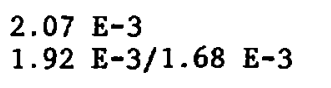 & 27 \\
\hline${ }^{228} \mathrm{AC}$ & $\begin{array}{l}616.06 \\
615.90\end{array}$ & $\begin{array}{l}4.51 \quad E-4 \\
9.00 E-4\end{array}$ & $\begin{array}{r}* \\
27\end{array}$ \\
\hline $228 \mathrm{AC}$ & $\begin{array}{l}665.90 \\
666.30\end{array}$ & $\begin{array}{ll}3.92 & E-4 \\
4.80 & E-4\end{array}$ & $\begin{array}{r}* \\
27\end{array}$ \\
\hline $228 \mathrm{AC}$ & $\begin{array}{l}701.84 \\
701.50\end{array}$ & $\begin{array}{l}2.114 \mathrm{E}-3 \\
2.04 \mathrm{E}-3\end{array}$ & $\begin{array}{r}* \\
27\end{array}$ \\
\hline $228 \mathrm{AC}$ & $\begin{array}{l}707.55 \\
707.30\end{array}$ & $\begin{array}{ll}2.15 & E-3 \\
1.62 & E-3\end{array}$ & 27 \\
\hline \multirow[t]{2}{*}{${ }^{228} \mathrm{AC}$} & $\begin{array}{l}727.08 \\
727.00\end{array}$ & $\begin{array}{ll}8.29 & E-3 \\
8.25 & E-3\end{array}$ & 27 \\
\hline & $\begin{array}{l}755.37 \\
755.20 \\
755.29\end{array}$ & $\begin{array}{ll}9.17 & \mathrm{E}-3 \\
1.14 & \mathrm{E}-2\end{array}$ & $\begin{array}{l} \pm \\
27 \\
15\end{array}$ \\
\hline
\end{tabular}


Table 4.8 (Continued)

\begin{tabular}{|c|c|c|c|}
\hline Nuclide & Energy (keV) & Quantum Yield & References \\
\hline $228 \mathrm{AC}$ & $\begin{array}{l}772.15 \\
772.10\end{array}$ & $\begin{array}{ll}1.30 & E-2 \\
1.68 & E-2\end{array}$ & $\begin{array}{r}* \\
27\end{array}$ \\
\hline${ }^{228} \mathrm{AC}$ & $\begin{array}{l}782.20 \\
782.00\end{array}$ & $\begin{array}{l}4.60 \mathrm{E}-3 \\
5.64 \mathrm{E}-3\end{array}$ & 27 \\
\hline${ }^{228} \mathrm{AC}$ & $\begin{array}{l}795.02 \\
794.80\end{array}$ & $\begin{array}{ll}3.84 & \mathrm{E}-2 \\
5.01 & \mathrm{E}-2\end{array}$ & 27 \\
\hline $228 \mathrm{AC}$ & $\begin{array}{l}830.60 \\
830.48 \\
830.40\end{array}$ & $\begin{array}{l}4.81 \mathrm{E}-3 \\
6.39 \mathrm{E}-3\end{array}$ & $\begin{array}{l}* \\
15 \\
27\end{array}$ \\
\hline${ }^{228} \mathrm{AC}$ & $\begin{array}{l}835.80 \\
835.70 \\
835.60\end{array}$ & $\begin{array}{l}1.54 \mathrm{E}-2 \\
1.88 \mathrm{E}-2\end{array}$ & $\begin{array}{r}* \\
15 \\
27\end{array}$ \\
\hline${ }^{228} \mathrm{AC}$ & $\begin{array}{l}840.41 \\
840.29 \\
840.20\end{array}$ & $\begin{array}{l}8.84 \mathrm{E}-3 \\
1.02 \mathrm{E}-2\end{array}$ & $\begin{array}{r}* \\
15 \\
27\end{array}$ \\
\hline${ }^{228} \mathrm{AC}$ & $\begin{array}{l}904.32 \\
904.20 \\
904.22\end{array}$ & $\begin{array}{l}6.16 \mathrm{E}-3 \\
9.00 \mathrm{E}-3\end{array}$ & $\begin{array}{r}* \\
27 \\
15\end{array}$ \\
\hline $228 \mathrm{AC}$ & $\begin{array}{l}911.30 \\
911.18 \\
911.10\end{array}$ & $\begin{array}{l}2.65 \mathrm{E}-1 \\
3.00 \mathrm{E}-1\end{array}$ & $\begin{array}{r}* \\
15 \\
27\end{array}$ \\
\hline${ }^{228} A C$ & $\begin{array}{l}944.03 \\
944.10\end{array}$ & $\begin{array}{ll}1.13 & \mathrm{E}-3 \\
1.11 \mathrm{E}-3\end{array}$ & $\begin{array}{r}* \\
27\end{array}$ \\
\hline${ }^{228} \mathrm{AC}$ & $\begin{array}{l}947.92 \\
948.00\end{array}$ & $\begin{array}{ll}9.75 & E-4 \\
1.26 & E-3\end{array}$ & $\begin{array}{r}* \\
27\end{array}$ \\
\hline $228_{A C}$ & $\begin{array}{l}958.70 \\
958.50\end{array}$ & $\begin{array}{ll}2.84 & \mathrm{E}-3 \\
3.27 & \mathrm{E}-3\end{array}$ & $\begin{array}{r}* \\
27\end{array}$ \\
\hline${ }^{228} \mathrm{AC}$ & $\begin{array}{l}964.87 \\
964.80 \\
964.60\end{array}$ & $\begin{array}{l}4.96 \mathrm{E}-2 \\
5.64 \mathrm{E}-2\end{array}$ & $\begin{array}{r}\div \\
15 \\
27\end{array}$ \\
\hline${ }^{228} \mathrm{AC}$ & $\begin{array}{l}969.08 \\
968.94 \\
968.90\end{array}$ & $\begin{array}{l}1.65 \mathrm{E}-1 \\
1.81 \mathrm{E}-1\end{array}$ & $\begin{array}{r}\star \\
15 \\
27\end{array}$ \\
\hline${ }^{228} \mathrm{AC}$ & $\begin{array}{l}976.17 \\
975.90\end{array}$ & $\begin{array}{l}4.20 \mathrm{E}-4 \\
5.40 \mathrm{E}-4\end{array}$ & 27 \\
\hline${ }^{228} \mathrm{AC}$ & $\begin{array}{l}988.27 \\
988.10\end{array}$ & $\begin{array}{ll}1.58 & \mathrm{E}-3 \\
1.98 & \mathrm{E}-3\end{array}$ & 27 \\
\hline${ }^{228} \mathrm{AC}$ & $\begin{array}{l}1016.47 \\
1016.70\end{array}$ & $\begin{array}{ll}6.16 & E-4 \\
2.55 & E-4\end{array}$ & 27 \\
\hline${ }^{228} \mathrm{AC}$ & $\begin{array}{l}1033.39 \\
1033.10\end{array}$ & $\begin{array}{ll}2.05 & E-3 \\
2.34 & E-3\end{array}$ & 27 \\
\hline
\end{tabular}


Table 4.8 (Continued)

\begin{tabular}{|c|c|c|c|}
\hline Nuclide & Energy (kev) & Quantum Yield & References \\
\hline $228_{A C}$ & $\begin{array}{l}1065.17 \\
1065.10\end{array}$ & $\begin{array}{l}3.83 \mathrm{E}-3 \\
1.53 \mathrm{E}-3\end{array}$ & $\begin{array}{r}* \\
27\end{array}$ \\
\hline${ }^{228} \mathrm{AC}$ & $\begin{array}{l}1153.88 \\
1153.60\end{array}$ & $\begin{array}{ll}2.64 & E-3 \\
1.65 & E-3\end{array}$ & $\begin{array}{r}\dot{*} \\
27\end{array}$ \\
\hline${ }^{228} \mathrm{AC}$ & $\begin{array}{l}1164.77 \\
1164.60\end{array}$ & $\begin{array}{ll}5.52 & E-4 \\
7.80 & E-4\end{array}$ & $\begin{array}{r}* \\
27\end{array}$ \\
\hline
\end{tabular}




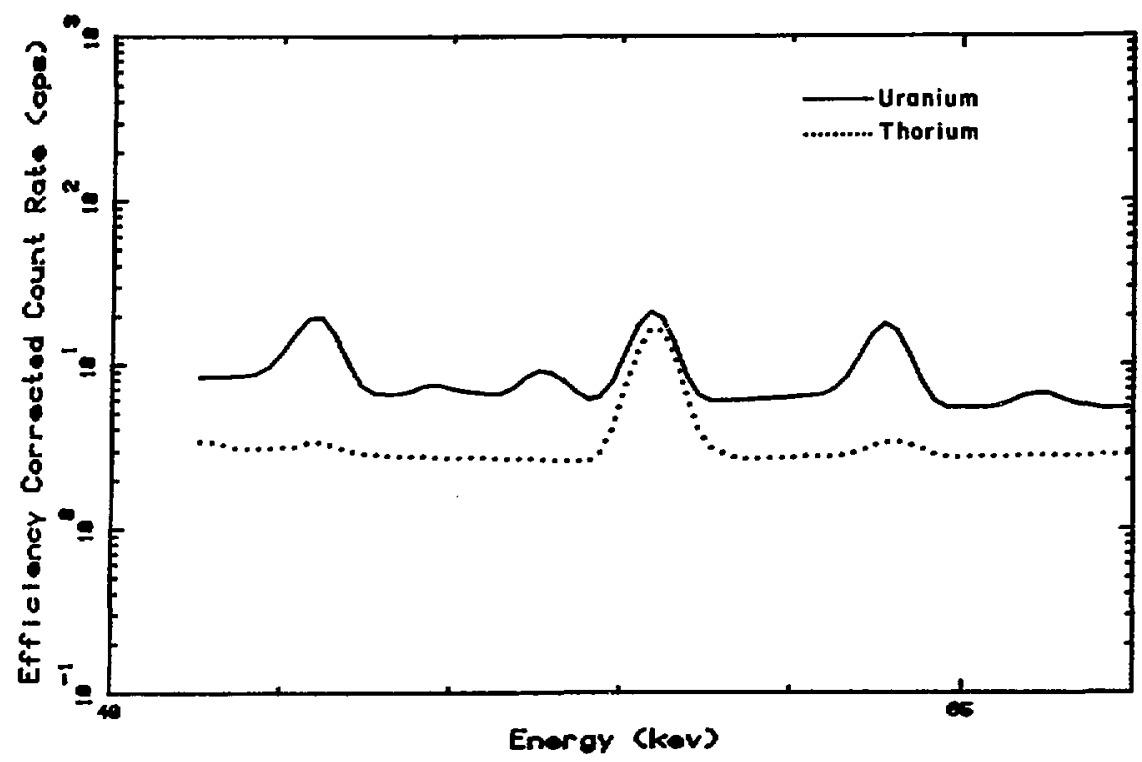

Figure 4.1. Gamma Spectra of the Uranium and Thorium Ores, $40-70 \mathrm{keV}$.

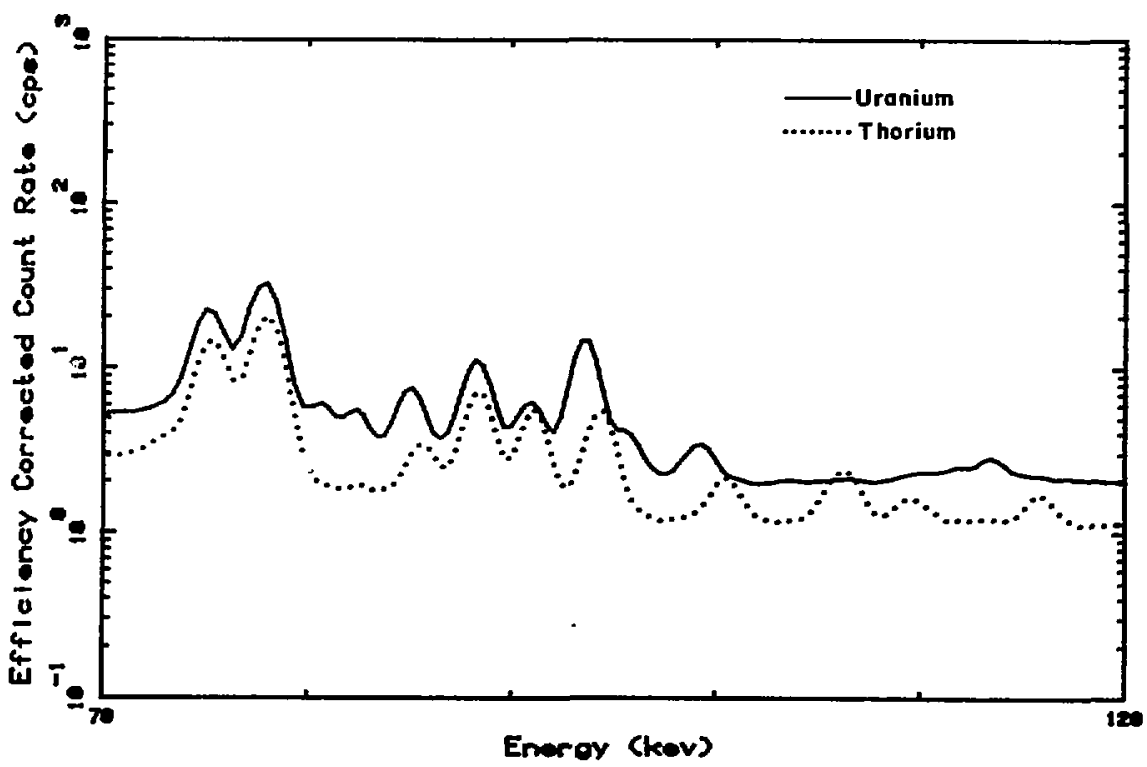

Figure 4.2. Gama Spectra of the Uraniun and Thoriun Ores, $70-120 \mathrm{keV}$. 


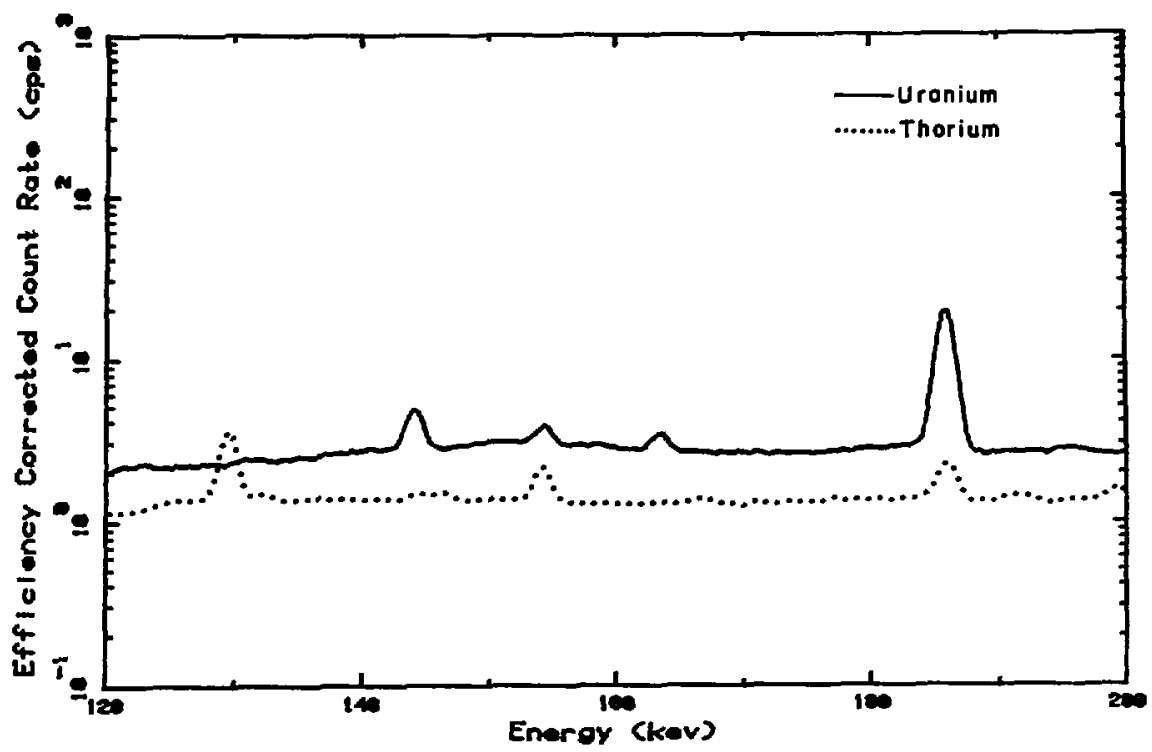

Figure 4.3. Gamma Spectra of the Uranium and Thorium Ores, $120-200 \mathrm{keV}$.

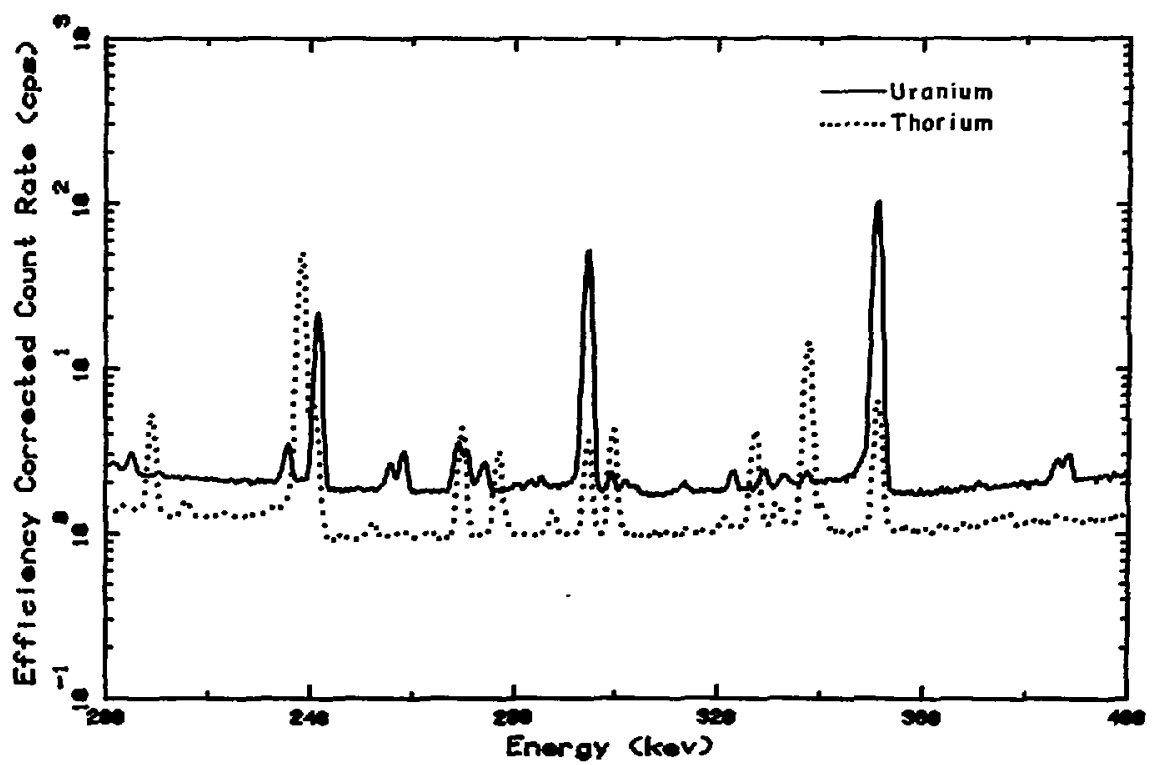

Figure 4.4. Gama Spectra of the Uranium and Thorium Ores, $200-400 \mathrm{keV}$. 

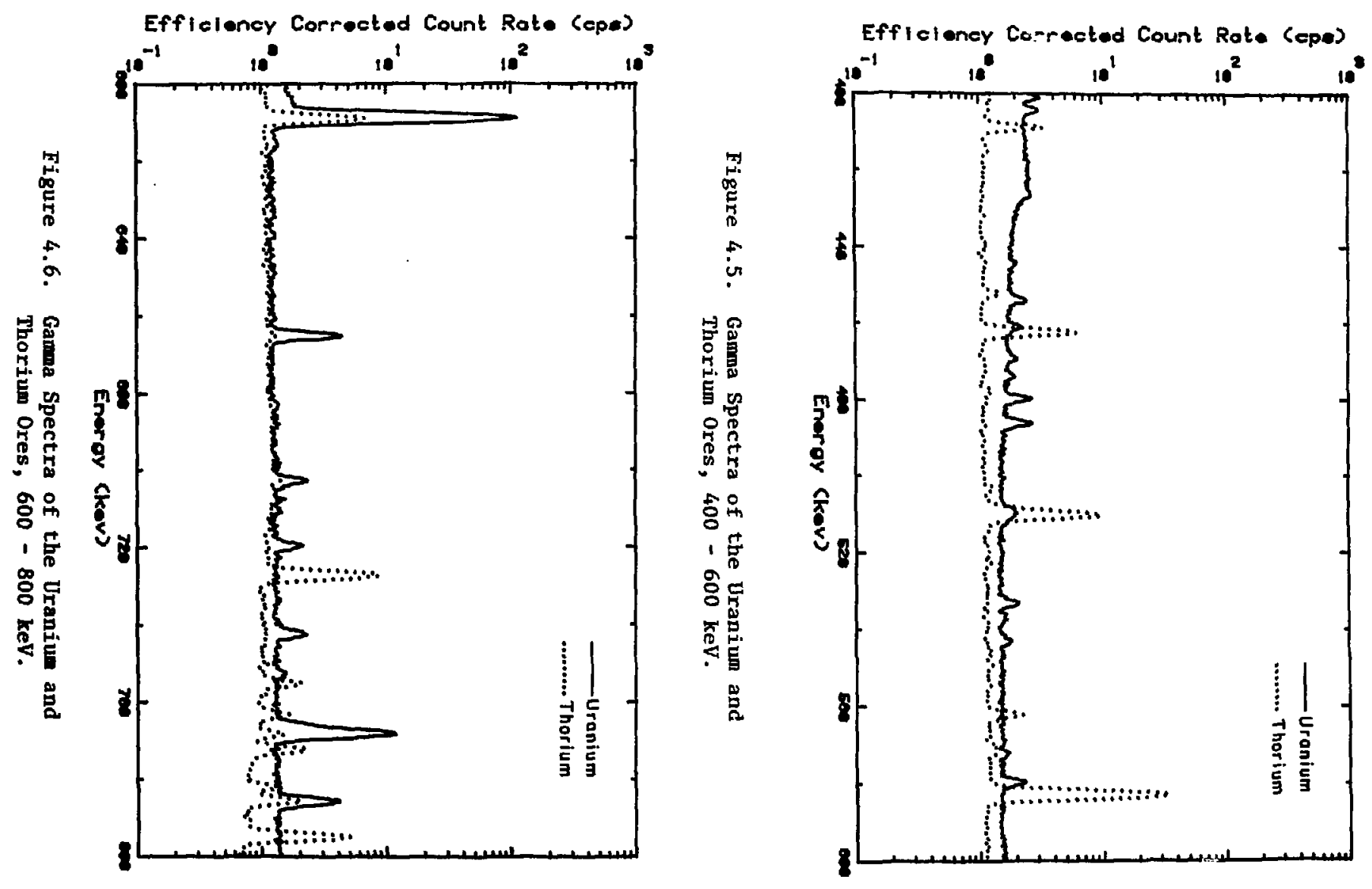


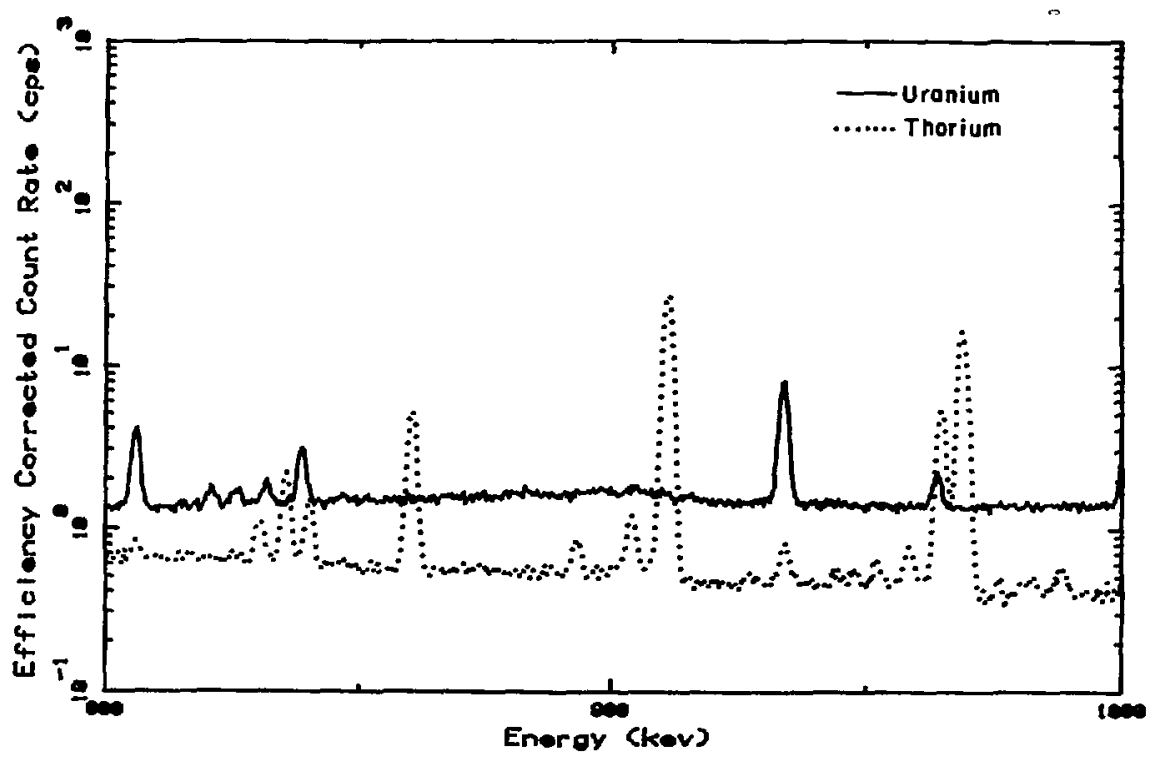

Figure 4.7. Gamma Spectra of the Uranium and Thorium Ores, $800-1000 \mathrm{keV}$.

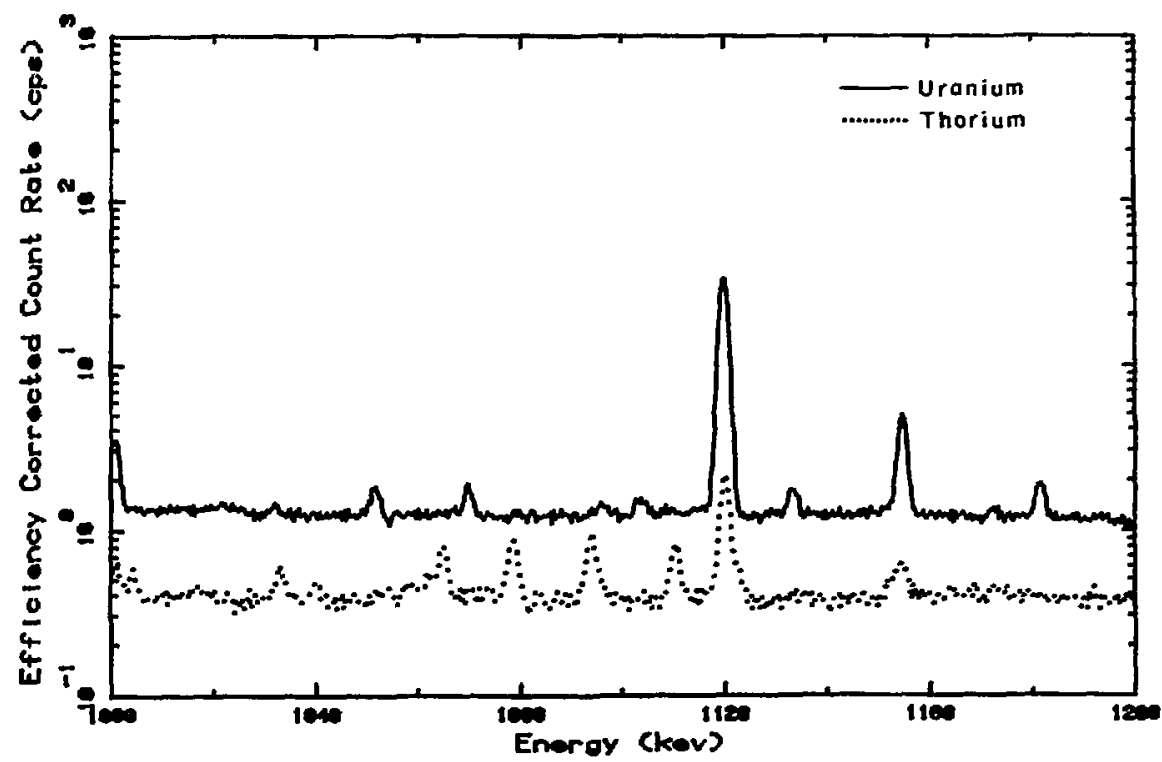

Figure 4.8. Gama Spectra of the Uraniun and Thorium Ores, $1000-1200 \mathrm{keV}$. 


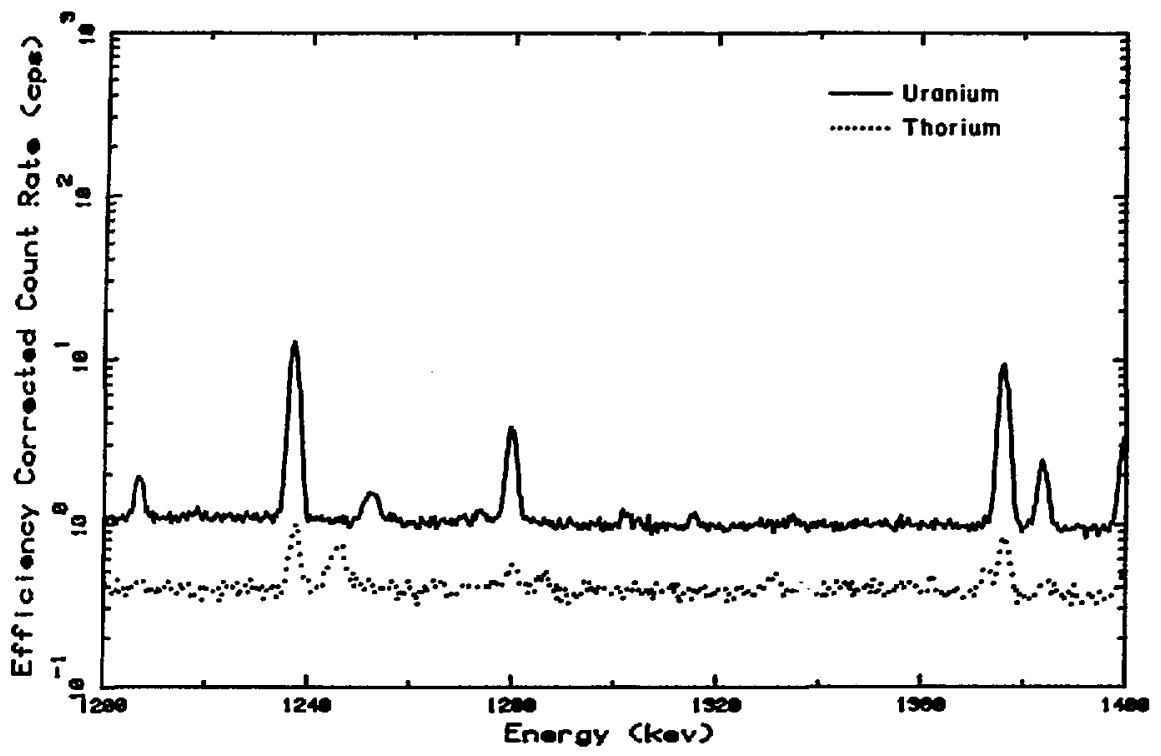

Figure 4.9. Ganna Spectra of the Uranium and Thorium Ores, $1200-1400 \mathrm{keV}$. 


\section{REFERENCES}

1. Adams, J.A.S., and P. Gasparini. 1970. "Gamma-Ray Spectroscopy of Rocks," American Elsevier Publishing Company, Inc., New York.

2. Bjornholm, S., et al. 1968. "Energy Levels in U-234 Propagated in the B-Decay of Pa-234(UZ)," Nuclear Physics, A118:261-301.

3. Brassard, J.R., and M.J. Correia. 1977. "A Computer Program for Fitting Multimodal Probability Density Functions," Computer Programs in Biomedicine 7 , p. 1-20.

4. Brown, K. M., and J.E. Dennis, Jr. 1970. "Derivative Free Analogues of the Levenberg-Marquardt and Gauss Algorithms for Nonlinear Least Squares Approximation," Numer. Math., 18:289-297.

5. Chu, Y.Y., and G. Scharff-Goldhaber. 1977. "Decay of Th-234 to the Pa-234 Isomers," Physical Review C, 17(4).

6. Davidson, W. C. 1965. "Variable Metric Method for Minimization," Argonne National Laboratory, ANL-5990 (Rev.).

7. Davidson, W.F., and R.D. Connor. 1968. "The Gamma-Ray Spectrum of Th-227," Nuclear Physics, A116:342-362.

8. Davidson, W.F., and R.D. Conror. 1970. "The Decay of Ra-223 and Its Daughter Products. I: The Decay of Ra-223," Nuclear Physics, A149:363-389.

9. Davidson, W.F., and R.D. Connor. 1970. "The Decay of Ra-223 and Its Daughter Products. II. The Decay of Rn-219 and Po-215," Nuclear Physics, A149: 385-391.

10. Fletcher, R. 1970. (FORTRAN Program included as an appendix of Ref. 10) Computer J., 13 (317). 
11. Fletcher, R., and M.J.D. Powe11. 1963. "A Rapidly Convergent Descent Method for Minimization," The Computer J., 6: 163-168.

12. Garbow, B.S. 1969. "Variable Metric Minimization," Argonne National Laboratory, ANL Z013.

13. Godart, J., and A. Gizon. 1973. "Niveaux de Pa-234. Atteints Par La Desintegration De Th-234," Nuclear Physics, A127:159-176.

14. Gunnink, R.J.B., et al. 1969. "Gamma-Ray Energies and Intensities," Lawrence Livermore Laboratory, UCID-15439.

15. Heath, R... 1975. "Gamma-Ray Spectrum Catologue Ge(Li) and Si (Li) Spectrometry," Third Edition, Physics TID-4500.

16. Hyde, E.K., J. Perlman, and G.T. Seaborg. 1964. "The Nuclear Properties of the Heavy Elements," Vol. II, Prentice-Ha11, Inc., Englewood Cliffs, NJ.

17. Kearn, Jean. 1969. "Computer Analysis of Nuclear Spectra and y-energy Standards," Nuclear Instruments and Methods, 79:233-239.

18. Kogan, R.M., I.M. Nazarov, and S.D. Fridman. 1969. "Gamma Spectrometry of Natural Environments and Formations, Moscow" (in Russian).

19. Kurcewicz, W., et al. 1977. "Precise Energies of Gamma Rays From the Th-230 and Th-228 Decay," Nuclear Instruments and Methods, 146:613-614.

20. Lederer, C.M., J.M. Hollander, and J. Perlman. 1968, 1978. "Table of Isotopes," 6 th and 7th Editions, John Wiley and Sons, Inc., New York.

21. Lingeman, E.W., et al. 1969. Nuclear Physics, 133:630.

22. McNelles, L.A., and J.L. Campbe11. 1975. "Analytic Approximations to Peak Shapes Produced by Ge(Li) and Si(Li) Spect.rometers," Nuclear Instruments and Methods, 127:73-81. 
23. Momeni, M.H. 1978. "Competitive Radiation-Induced Carcinogenesis: An Analysis of Data From Beagle Dogs Exposed to Ra-226 and Sr-90," Health Phys., 36:295-310.

24. Op De Beeck, J. 1975. "Gamma-Ray Spectrometry Data Collection and Reduction by Simple Computing Systems," Atomic Energy Review, 13(4).

25. Phillips, G.W., and K.W. Marlow. 1976. "Automatic Analysis of Gamma-Ray Spectra From Germanium Detectors," Nuclear Instruments and Methods,

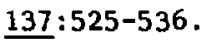

26. Sampson, T.E. 1973. "Precision Measurement of Gamma-Ray Energies From U-238 Daughters, II," Nuclear Instruments and Methods, 111:209-211.

27. Smith, A.K., and H.A. Wollenberg. 1972. "High-Resolution Gamma Ray Spectrometry for Laboratory Analysis of the Uranium and Thorium Decay Series," Natural Radiation Env., Vol. 1, US-ERDA.

28. Taylor, H.W. 1973. "Gamma-Ray Emitted by Uranium and Thoriun in the Energy Range 10-120 keV," International Journal of Applied Radiation and Isotopes, 23:593-597.

29. Teoh, W., R.D. Connor, and R.H. Betts. 1974. "The Decay of U-235," Nuclear Physics, A228:432-444.

30. Zobel, V., et al. 1976. "Ra-226 as Calibration Standard for Ge(Li) Spectrometers," Nuclear Instruments and Methods, 141:329-336. 
APPENDIX A. PREPARATION AND ANALYSIS OF STANDARDS

Standards were prepared by mixing $1 \mathrm{~g}$ of the ore into a sand matrix to a total weight of about $10 \mathrm{~g}$. The solutions were pipetted into a $10-\mathrm{g}$ sand matrix, dried, and placed in a two-piece rigid plastic, cylindrical container (4.1 $\mathrm{mm}$ in diameter by $1.6 \mathrm{~mm}$ high) and covered with a cellulose filter. The samples were packed with a pneumatic press to a height of about $5 \mathrm{~mm}$ and then covered with hot wax. Finally, the plastic lid was greased with a high vacuum compound and the sample was sealed. Similar procedures were applied to all samples and blanks, except for those already in a sand matrix, e.g., uranium ore and soil.

\section{Radium Standards}

The standards were prepared from a radium-226 solution and clean beach sand according to the procedure described above. Ten grams of sand were mixed with $1 \mathrm{ml}$ of the solution, dried at room temperature, and covered with hot wax. Each standard was then measured by the same technique previously utilized for calibration. The measurements were repeated 50 days after sample preparation.

In addition, two aliquots (each of $25 \lambda$ volume) of the same radium solution were heated on two steel disks to evaporate the polonium. The radium was then measured by alpha spectroscopy. The activities of the two samples, measured for a duration of 2000 seconds, were $1344.0 \mathrm{pCi} / \mathrm{ml}$ and $1340.7 \mathrm{pCi} / \mathrm{ml}$, with the average of $1342.4 \mathrm{pCi} / \mathrm{m} 1$. On the basis of these measurements, the activities of the two radium-226 standards in the sand matrix were deterniced to be $1355.8 \mathrm{pCi}$ (standard A) and 1342.4 (standard B), with an average of. 1349.1 pCi. 
Results of the spectrographic analyses of radium standards $A$ and $B$, for the counting period $1.5 \times 10^{5} \mathrm{sec}$, are shown in Tables A.1 through A.6. The activities of the standards are $1262.8 \mathrm{pCi}$ (A) and $1279.6 \mathrm{pCi}$, with errors of about $1 \%$ from detection of a $186 \mathrm{keV}$ peak of $\mathrm{Ra}-226$. The average activities from detection of $\mathrm{Pb}-214$ peaks are $1226.1 \mathrm{pCi}$, with a $0.48 \%$ error for standard $\mathrm{A}$, and $1357.3 \mathrm{pCi}$, with a $0.28 \%$ error for standard $\mathrm{B}$. The average activities from the detection of $\mathrm{Bi}-214$ peaks are $1234.4 \mathrm{pCi}$, with $\mathrm{a} 0.48 \%$ error for standard A, and $1360.2 \mathrm{pCi}$ with a $0.39 \%$ error. Comparison of standards A and $B$ indicates that the activity of standard $B$ is higher, in contrast to the results of the alpha spectroscopy. However, the difference is small and well within the expected range of the statistical variation. The average of the activities of standards $A$ and $B$ is 1271.2 pCi from $\mathrm{Ra}-226,1291.7 \mathrm{pCi}$ from $\mathrm{Pb}-214$, and $1297.3 \mathrm{pCi}$ from $\mathrm{Bi}-214$. The average of all of the measurements is 1286.7 $\mathrm{pCi}$ for Ra-226. The difference between the average activity determined by alpha spectroscopy and that determined by gamma spectroscopy is only $4.85 \%$. Since the error of pipetting $25 \lambda$ is larger than that of pipetting $1 \mathrm{ml}$, the difference could be largely due to sample preparation. Thus, the activity of the solution is the average of the activities determined by gamma spectroscopy.

Pitchblende Ore Standard No. 6*

A sample of the ore was dried to a constant weight. Then $0.502 \mathrm{~g}$ of the ore was mixed with $23.451 \mathrm{~g}$ of clean beach sand with low specific activity and the mixture divided into two samples, 6A (11.964 g) and 6B (11.929 g). The ore made up only $2.096 \%$ of the sample. The activities of the samples were calculated on the basis of the natural abundance of the U-238 isotope (99.28\%), the decay coefficient $\lambda\left(1.537 \times 10^{-10} /\right.$ year $)$ and the ratio $\mathrm{U}_{3} / \mathrm{U}_{3} \mathrm{O}_{8}(0.849)$. The control sample was prepared with $12.0 \mathrm{~g}$ of beach sand. The U-238 activities of the samples were:
$6 \mathrm{~A}$
$3.7715 \times 10^{4} \mathrm{pCi}$
6B
$3.7605 \times 10^{4} \mathrm{pCi}$
Control
$3.50 \mathrm{pCi}$

*v.S. Atomic Energy Commission, New Brunswick Laboratory. The sample (dried at $110^{\circ} \mathrm{C}$ ) contained $53.55 \% \mathrm{U}_{3} \mathrm{O}_{8}$. 
Since the samples were prepared in 1978, the activity had reached secular radioactive equilibrium with respect to $\mathrm{Po}-218, \mathrm{~Pb}-214$, and $\mathrm{Bi}-214$ (radon daughters).

The results of gamma spectroscopic analysis of this sample are shown in Table A.7. The mean activities and the detection limits are given in Tables A.8 and A.9. The mean activity of the members of the U-238 series is about $3.77 \times 10^{4} \mathrm{pCi}$, with the lowest error $(0.16 \%)$ for $\mathrm{Pb}-214$ and the highest (13.69\%) for U-234. This activity is in good agreement with the activity of the standards. The activity of the members of the actinium series is about $1.77 \times 10^{3} \mathrm{pCi}$ with the lowest error (1.34\%) for Ra-223 and the highest (14.54\%) for $\mathrm{Pa}-231$. The ratio of the specific activity of $\mathrm{U}-238$ to that of $\mathrm{U}-235$ is 21.299 , in good agreement with the ratio of 21.348 calculated from the natural abundances of these two nuclides. The activity of the thorium series in the ore sample was not detectable (Table A.9).

Pitchblende Ore Standard No. 100*

The activities of selected radionuclides in this reference material have been carefully and extensively measured (Sill and Willis 1965; Sill and Williams 1969; Sill and Hindman 1974; Sill 1976). These measurements indicated that the sample was in secular radioactive equilibrium with the recommended activity for the uranium series $6.06 \pm 0.04 \times 10^{3}$ disintegrations per minute per gram $(\mathrm{dpm} / \mathrm{g})$ and for the actinium series $2.82 \pm 0.09 \times 10^{2}(\mathrm{dpm} / \mathrm{g})$.

The Percival and Martin (1974) analysis of the same ore sample produced the activities (at a $95 \%$ confidence level) for members of each series. $1.8873 \mathrm{~g}$ of the ore was mixed with beach sand to a total weight of $12 \mathrm{~g}$. The results of this analysis are in Tables A.10, A.11, and A.12.

The mean activity of $\mathrm{Pa}-234 \mathrm{~m}$ is $5.587 \times 10^{3} \mathrm{pCi}$ with an error of $3.20 \%$ (Table A.11). The activities for the individual lines and the errors of the

*Made available by Claude Sill, Health Services Laboratory, U.S. Energy Research and Development Administration, Idaho Falls, Idaho. 
measurements of $\mathrm{Pa}-234 \mathrm{~m}$ are $5.603 \times 10^{3} \mathrm{pCi}(4.95 \%)$ at $742.8 \mathrm{keV}$ and $5.576 \times$ $10^{3} \mathrm{pCi}(4.20 \%)$ at $766.4 \mathrm{keV}$. The lines at $258.4 \mathrm{keV}$ and $1001.1 \mathrm{keV}$ interfere with the activity of $\mathrm{Pb}-214$ and $\mathrm{Bi}-214$, respectively. The activities from these lines have been incorporated into the mean value, even though they are not listed here. The activity of $\mathrm{Pa}-234 \mathrm{~m}$ is a measure of $\mathrm{U}-238$ activity under secular radioactive equilibrium. The activity of the other nuclide in U-238, $\mathrm{Pa}-234$, could not be determined (Table A.12) since the line at $946.0 \mathrm{keV}$ (a major line) was not statistically observable. The previously reported activity for this ore is $6.06 \pm 0.04 \times 10^{3} \mathrm{dpm} / \mathrm{g}$, corresponding to $5.158 \times 10^{3} \mathrm{pCi}$ (Sill 1977; Percival and Martin 1974).

The activity of U-234, calculated from the $53.1 \mathrm{keV}$ line (Table A. 10), is $9.837 \times 10^{3} \mathrm{pCi}(14.73 \%)$. However, this line has interference from $\mathrm{Pb}-214$, but since the mean activity of $\mathrm{Pb}-214,5.337 \times 10^{3} \mathrm{pCi}(3.61 \%)$, has been used for correction of the interference, the activity for $\mathrm{U}-234$ (Table A.11) is a reasonable estimate for the nuclide. This calculated activity suggests that the ore sample is not in secular radioactive equilibrium with respect to $U-238$ and $\mathrm{U}-234$.

Thorium-230 activity was determined (Table A.10) from the $67.6 \mathrm{keV}$ and the $143.8 \mathrm{keV}$ lines to be $4.788 \times 10^{3} \mathrm{pCi}(9.7 \%)$. The mean $\mathrm{Th}-230$ activity is shown in Table A.11. The $143.8 \mathrm{keV}$ line has interference from $\mathrm{Ra}-223$ and $\mathrm{U}-235$. But since the activity of either Pa-234m or U-234 is used for correction of the interference, the calculated Th-230 activity is a reasonable estimate. This result suggests a lack of equilibrium between U-234 and Th-230.

The mean activities of $\mathrm{Ra}-226, \mathrm{Bi}-214$, and $\mathrm{Pb}-214$ (Table $\mathrm{A} .11$ ) are $6.063 \times$ $10^{3} \mathrm{pCi}(2.59 \%), 5.316 \times 10^{3} \mathrm{pCi}(0.2 \%)$, and $5.337 \times 10^{3} \mathrm{pCi}(3.61 \%)$ respectively. The mean activities of $\mathrm{Bi}-214$ and $\mathrm{Pb}-214$ are in good agreement, but the activity of $\mathrm{Ra}-226$ is $7 \%$ higher than the mean activities of the two radon ( $\mathrm{Rn}-222$ ) daughters. Since the only usable line for Ra-226 is $186.0 \mathrm{keV}$ (Table A.10), and this line is in interference with U-235 activity at $185.7 \mathrm{keV}$, the $7 \%$ may be introduced from the U-235 correction. The mean U-235 activity (Table A.11) is $1.875 \times 10^{2} \mathrm{pCi}(6.55 \%)$. If the ratio of the activity of $\mathrm{U}-235$ to that of $\mathrm{U}-238$ is proportional to the ratio of the natural abundance of $\mathrm{U}-235$ to that 
of U-238, then, on the basis of the Pa-234n activity, that of U-235 should be $2.617 \times 10^{2} \mathrm{pCi}$. The activity of $\mathrm{U}-235$ was determined from the following lines: $\quad 114.4 \mathrm{keV}\left[1.301 \times 10^{2} \mathrm{pCi}(10.55 \%)\right], 139.8 \mathrm{keV}\left[1.873 \times 10^{3} \mathrm{pCi}\right.$ $(12.90 \%)], 163.3 \mathrm{keV}\left[3.785 \times 10^{2} \mathrm{pCi}(7.6 \%)\right], 194.9 \mathrm{keV}\left[6.836 \times 10^{2} \mathrm{pCi}\right.$ $(15.35 \%)]$, and two lines at $143.8 \mathrm{keV}$ and $241.9 \mathrm{keV}$, both complicated by interference. The mean $\mathrm{U}-235$ activity is $1.875 \times 10^{2} \mathrm{pCi}(6.55 \%)$ (Table A.11), with a range of $1.3 \times 10^{2}$ to $6.84 \times 10^{2} \mathrm{pCi}$. Thus, the $7 \%$ difference between the Ra-226 activity and those of Bi-214 and $\mathrm{Pb}-214$ is not significant, and a better estimate for the $\mathrm{Ra}-226$ activity is the average of the mean activities for $\mathrm{Bi}-214$ and $\mathrm{Pb}-214,5.327 \times 10^{3} \mathrm{pCi}$, which is in agreement with those reported by Percival and Martin (1974) and Sill et a]. (1977).

The activity of $\mathrm{Pb}-210\left[5.928 \times 10^{3} \mathrm{pCi}(1.10 \%)\right]$ is $10 \%$ larger than the radon daughter activities. This difference seems to be significant and needs further evaluation. The mean activities of the U-235 daughters (Table A.11) are $2.401 \times 10^{2} \mathrm{pCi}(1.52 \%)$ for $\mathrm{Rn}-219,2.249 \times 10^{2} \mathrm{pCi}(1.82 \%)$ for Th-227, $2.367 \times 10^{2} \mathrm{pCi}(1.53 \%)$ for $\mathrm{Ra}-223$, and $2.116 \times 10^{2} \mathrm{pCi}(27.5 \%)$ for $\mathrm{Pa}-231$.

The activity of $\mathrm{Pa}-234 \mathrm{~m}$, estimated from the average activity of the actinium series, is $4.88 \times 10^{3} \mathrm{pCi}$, which is smaller than the mean activity of Pa-234m shown in Table A.11, $5.587 \times 10^{3} \mathrm{pCi}$. The activity of Th-234 is $5.428 \times 10^{3} \mathrm{pCi}(1.30 \%)$, which is in agreement with the $\mathrm{Pa}-2.34 \mathrm{~m}$ activities measured directly from the spectrum. Thus, the differences between U-238, U-234, and U-235 may not be an artifact and, although small, (about 10\%) may be a real observation. 
Table A.1. Gamma Spectrographic Analysis of Radium Standard A

RA STAHDARD A COHPLETE EQUL IINIUH

\author{
COUNT TIME (SEC)\& $1.50000 E$ OS \\ ENERGY CALIDRATIOA. \\ ID: MOV. 17/80 OFF $\approx 80$ GAIH=100/F6 \\ EFFICIEHCY CALIBRATION $I$ \\ II: NOV. $12 / 80$ OFF $=80 \mathrm{G}=100 / \mathrm{F} 6 \mathrm{E}=155 / 6 / 0 / 2000$
}

EFFIC. CORRECTED COUNT RATE

REGION : 1 TO 4000

\begin{tabular}{|c|c|c|c|c|c|c|c|c|}
\hline $\begin{array}{l}\text { PK. } \\
\text { HO. }\end{array}$ & $\begin{array}{l}\text { CEHTR. } \\
\text { CHAH. }\end{array}$ & $\begin{array}{c}\text { CENTR. } \\
\text { KEV }\end{array}$ & $\begin{array}{l}\text { ERROR } \\
\text { CHAN. }\end{array}$ & $\begin{array}{l}\text { FUHH } \\
\text { KEV }\end{array}$ & $\begin{array}{l}\text { AREA } \\
\text { COUNTS }\end{array}$ & $\begin{array}{r}\text { CNT . RAIE } \\
\text { CNTS/SEC }\end{array}$ & $\begin{array}{l}\text { ERROK } \\
x \text { AREA }\end{array}$ & $\begin{array}{l}\mathrm{C} \\
\mathrm{C}\end{array}$ \\
\hline 1 & 16.5 & 29.99 & 1.73 & 1.42 & 806 & $1.1688 E-01$ & 42.85 & 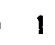 \\
\hline 2 & 37.9 & 35.86 & 0.01 & 1.23 & 777074 & $9.0 \%$ st 01 & 0.35 & \\
\hline 3 & 75.7 & $4 \$ .48$ & 0.10 & 1.26 & 6446 & $5.6894 E-111$ & 4.00 & \\
\hline 4 & 98.8 & 53.09 & 0.07 & 1.21 & 5142 & $4.0245 E-01$ & 2.90 & \\
\hline 5 & 173.2 & 74.90 & 0.04 & 1.26 & 47116 & $2.9024 E 00$ & 1.30 & $* 1$ \\
\hline 6 & 181.1 & 77.26 & 0.02 & 1.26 & 83187 & $5.0457 E 013$ & 0.85 & $* 1$ \\
\hline 7 & 189.0 & 79.63 & 0.21 & 1.26 & 5312 & $3.1 \% 73 E-01$ & 8.20 & $* 1$ \\
\hline 8 & 204.1 & 84.16 & 0.15 & 1.37 & 3279 & $1.91805-01$ & 9.75 & : \\
\hline 9 & 215.8 & 87.68 & 0.03 & 1.37 & 28141 & $1.623 . \mathrm{E} 00$ & 1.50 & $\star$ \\
\hline 10 & 224.9 & 90.43 & 0.05 & 1.37 & 10495 & $6.0045 E-01$ & 2.70 & $*$ \\
\hline 11 & 234.6 & 93.34 & 0.33 & 1.37 & 1271 & $7.2210 \mathrm{E}-02$ & 13.55 & $*$ \\
\hline 12 & 557.0 & 186.35 & 0.03 & 1.32 & 23254 & 2.0366E 00 & 1.00 & \\
\hline 13 & 749.0 & 242.21 & 0.03 & 1.28 & 30683 & $3.4697 \mathrm{E} 00$ & 1.05 & \\
\hline 14 & 806.9 & 259.04 & 0.11 & 1.26 & 1779 & $2.1521 E-01$ & 4.95 & \\
\hline 15 & 861.2 & 274.83 & 0.17 & 1.50 & 1245 & $1.6022 \mathrm{E}-01$ & 7.80 & \\
\hline 16 & 932.1 & 295.47 & 0.01 & 1.33. & 64061 & $8.9193 E 00$ & 0.55 & \\
\hline 17 & 1127.2 & 352.24 & 0.01 & 1.36 & 101104 & $1.7173 E 01$ & 0.50 & \\
\hline 18 & 1246.5 & 386.97 & 0.25 & 1.25 & 544 & $1.0283 E-01$ & 12.55 & \\
\hline 19 & 1254.2 & 389.21 & 0.21 & 1.25 & $8 \delta 2$ & $1.0401 E-01$ & 9.55 & \\
\hline 20 & 1480.8 & 455.15 & 0.39 & 1.68 & 490 & $1.1036 E-01$ & 17.90 & \\
\hline 21 & 1504.3 & 462.02 & 0.49 & 1.19 & 274 & $3.380, \bar{E}-02$ & 24.35 & \\
\hline 22 & 1508.9 & 463.36 & 0.59 & 1.19 & 218 & $5.0004 E-02$ & 25.60 & \\
\hline 23 & 1532.3 & 470.17 & 0.50 & 1.18 & 263 & $6.1222 E-02$ & 24.10 & \\
\hline 24 & 1569.4 & 480.97 & 0.27 & 1.27 & 630 & $1.5003 E-01$ & 11.85 & \\
\hline 40 & 1591.7 & $487.47^{\circ}$ & $0.28^{-}$ & T.01 & $677^{\circ}$ & $1.6339 E-01$ & 12.00 & \\
\hline
\end{tabular}


Table A.1. (cont'd)

$\begin{array}{rrrrrrrrr}26 & 1673.1 & 511.15 & 0.44 & 1.78 & 1082 & 2.7370 E-01 & 9.35 & 1 \\ 27 & 1752.3 & 534.23 & 0.41 & 1.52 & 387 & 1.0233 E-01 & 16.60 \\ 28 & 1911.8 & 580.68 & 0.29 & 1.15 & 404 & 1.1715 E-01 & 14.31 \\ 29 & 2012.1 & 609.88 & 0.01 & 1.51 & 62088 & 1.4247 E & 01 & 0.60 \\ 30 & 2205.0 & 666.08 & 0.11 & 1.51 & 1669 & 5.5188 E-01 & 4.25 \\ 31 & 2334.9 & 703.93 & 0.26 & 1.40 & 427 & 1.4825 E-01 & 10.75 \\ 32 & 2391.9 & 720.53 & 0.42 & 1.88 & 379 & 1.3444 E-01 & 13.85 \\ 33 & 2470.0 & 743.28 & 0.23 & 1.36 & 409 & 1.4940 E-01 & 10.55 \\ 34 & 2558.8 & 769.15 & 0.06 & 1.63 & 5131 & 1.9377 E 00 & 1.80 \\ 35 & 2618.9 & 786.64 & 0.13 & 1.65 & 1273 & 4.9168 E-01 & 4.45 \\ 36 & 2688.6 & 806.95 & 0.11 & 1.65 & 1271 & 5.0385 E-01 & 4.20 \\ 37 & 2801.6 & 939.96 & 0.22 & 1.46 & 670 & 2.7696 E-01 & 9.25 \\ 38 & 3128.0 & 934.95 & 0.08 & 1.65 & 2574 & 1.1978 E 00 & 2.75 \\ 39 & 3231.2 & 965.00 & 0.32 & 1.06 & 260 & 1.2546 E-01 & 19.05 \\ 40 & 3533.7 & 1053.10 & 0.57 & 1.69 & 220 & 1.1745 E-01 & 18.40 \\ 11 & 3788.0 & 1121.29 & 0.03 & 1.77 & 11400 & 6.5360 E 00 & 0.85 \\ 12 & 3887.8 & 1156.17 & 0.12 & 1.60 & 1184 & 7.0191 E-01 & 4.20 \\ 13 & 3950.3 & 1174.36 & 1.96 & 1.15 & 210 & 1.2656 E-01 & 70.30 & 1 \\ 44 & 3965.1 & 1178.68 & 0.01 & 1.15 & 776315 & 4.6968 E 02 & 0.45 & 1\end{array}$

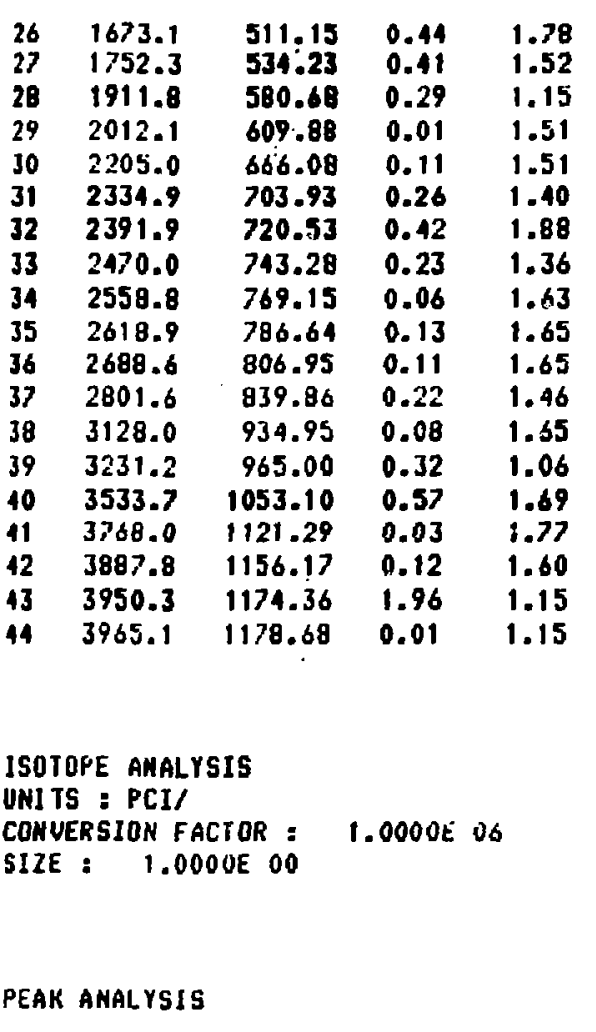

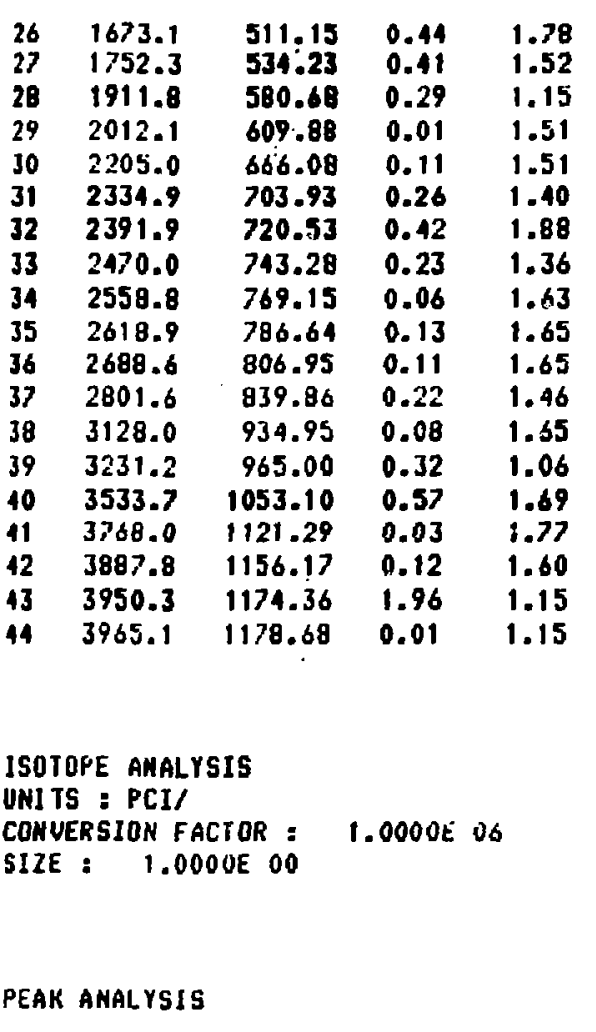

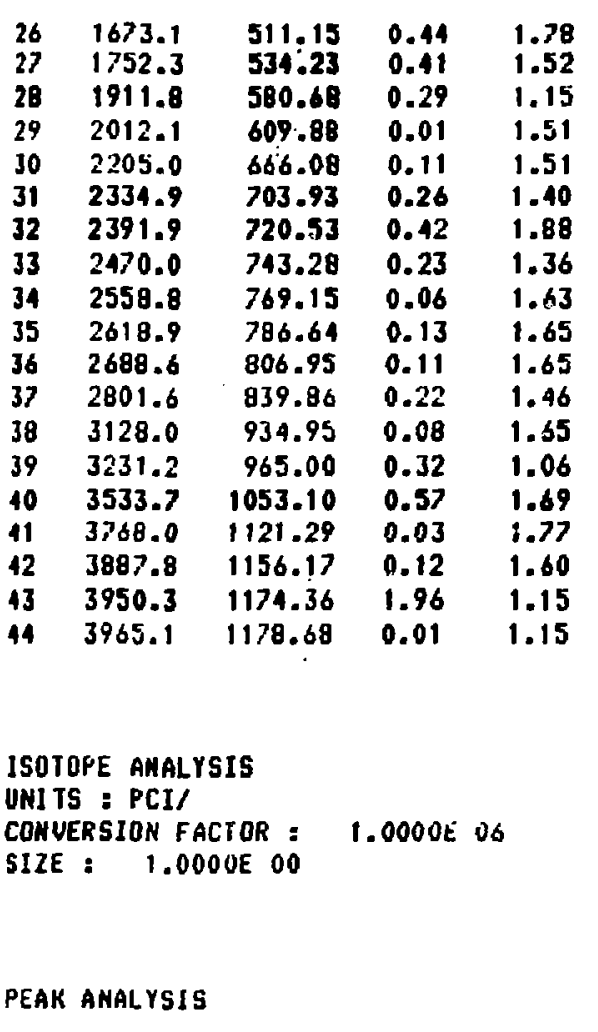

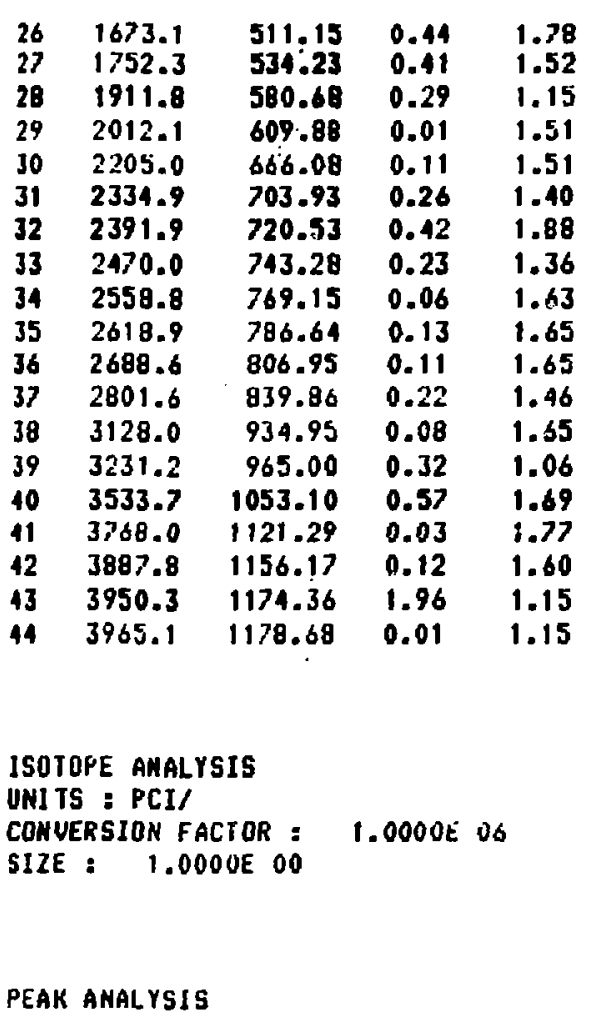

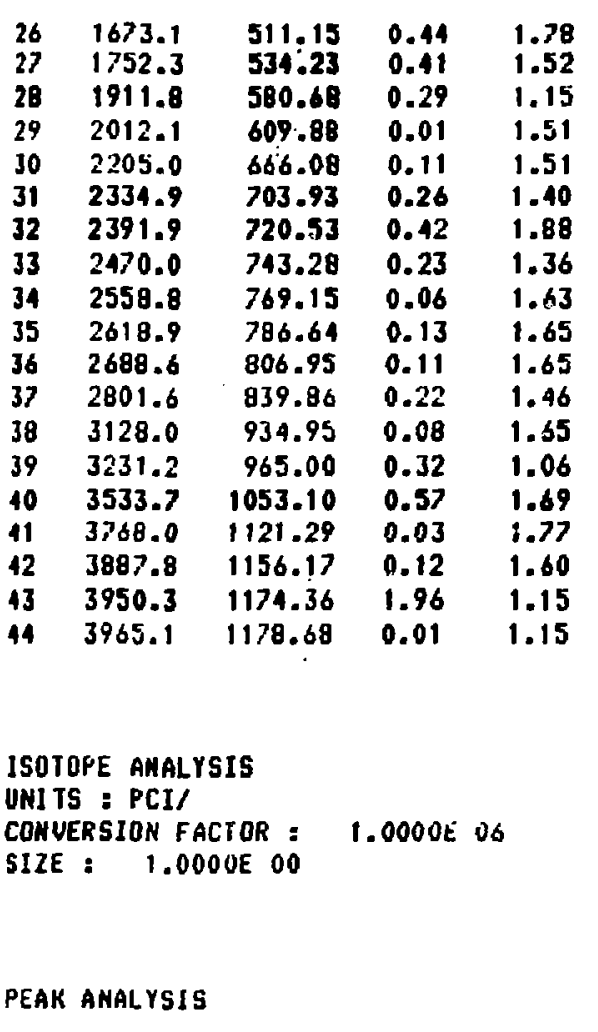

GAMHA ACTIVITY $\%$ ERROR

KENT NUCLIDE TYPE GANHA
KEV

$46.54 .6358 E 02$

4.00

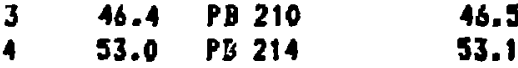


Table A.1. (cont'd)

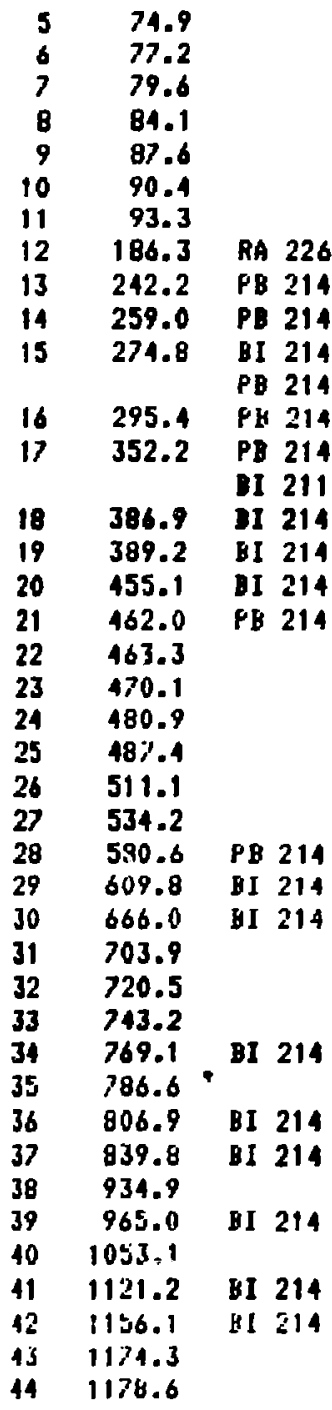

$186.0 \quad 1.2628 E \quad 03$

1.00

241.9 1.2249E 03

1.05

$259.1 \quad 2.7744 E 03$

4.95

274.5

274.8

$295.2 \quad 1.2235 E \quad 03$

0.55

351.9

2351.9 OE OO

386.8 1.2446E 03

$388.9 \quad 1.3371 E$ O3

$454.5 \quad 1.3272 \mathrm{E} \mathrm{O3}$

$462.2 \quad 9.2306 E 02$

12.55

9.55

17.90

24.35

$580.3 \quad 9.9550 E \quad 02$

14.30

$609.5 \quad 1.232,7 E 03$

0.60

$665.6 \quad 1.2579503$

4.25

$768.5 \quad 1.1410 E^{03}$

1.80

$806.2 \cdot 1.3080$ O3

4.20

$839.1 \quad 1.142$ SE 03

9.25

$964.1 \quad 1.0486 \mathrm{E} 03$

19.05

1120.2 1.2631E OS

0.85

$115 \mathrm{~s} .1$ 1.1444t 03

4.20 
Table A.2. Mean Activities of Nuclides in Radium Standard A NEAK ACIIUITIES

\begin{tabular}{|c|c|c|c|c|c|}
\hline NUCL \&HE & IYPE & ACTIVIIY & X ERROR & x CHIso & HALF[MIR] \\
\hline $\begin{array}{l}\text { RA } 226 \\
\text { PB } 210\end{array}$ & & $\begin{array}{l}1.2628 E \text { OJ } \\
4.6358 E \text { O2 }\end{array}$ & $\begin{array}{l}1.00 \\
4.00\end{array}$ & $\begin{array}{l}0 \\
0\end{array}$ & $\begin{array}{ll}8.40 E & 08 \\
1.1 & 07\end{array}$ \\
\hline $\begin{array}{l}\text { BI } 211 \\
\text { PI } 214 \\
\text { BI } 214\end{array}$ & 2 & $\begin{array}{r}0 E \text { OO } \\
1.2261 E \\
1.23 \text { O3 }\end{array}$ & $\begin{array}{r}0 \\
0.48 \\
0.46\end{array}$ & $\begin{array}{r}0 \\
2.78 \\
0.84\end{array}$ & $\begin{array}{ll}2.15 E & 00 \\
2.67 E & 01 \\
1.97 E & 01\end{array}$ \\
\hline
\end{tabular}

Table A.3. Detection Limits of Nuclides in Radium Standard A

DETECIION LIMITS

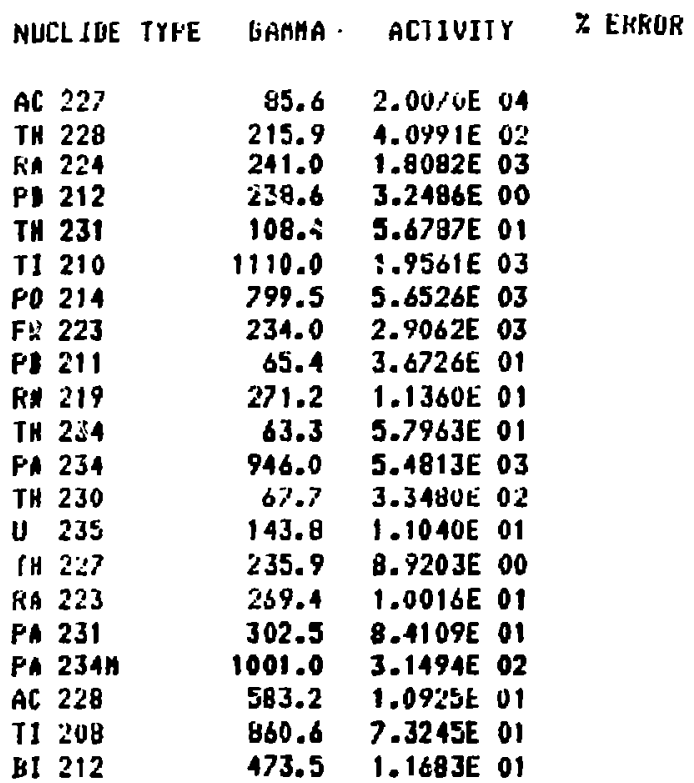


Table A.4. Gamma Spectrographic Analysis of Radium Standard B

PAMIIH 226 STAMLARE I EQUILIDKIUM

COUNT TINE (SEC): 1.50000 OS

EHERGY CAL IBRATION

ID: $H O V .17 / 80$ OFF $=80$ GAIN $=100 / F 6$

EFF ICIEMCY CALIBRATION 1

ID: NOV. $12 / 80$ OFF $=80 \quad G=100^{\circ} / F 6 \quad E=155 / 610 / 2000$

EFFIC. CORKECTEL CUUNI KAIE

REGION: $\quad 1$ 10 4000

PK. CENTR. CENTK. ERROR FHHM AKEA CNT. RATE ERTUK C

NO. CHAH. KEV CHAH., KEV COUHSS CHIJ/SEC $Z$ GKEA $C$

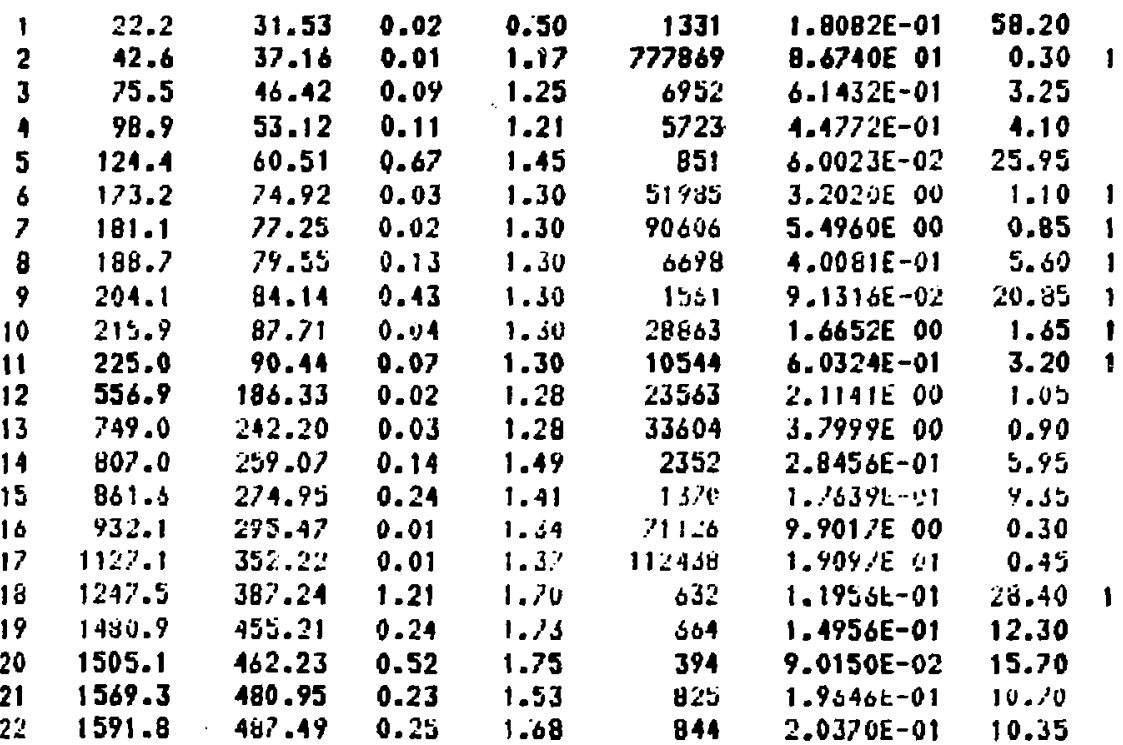


Table A.4. (cont'd)

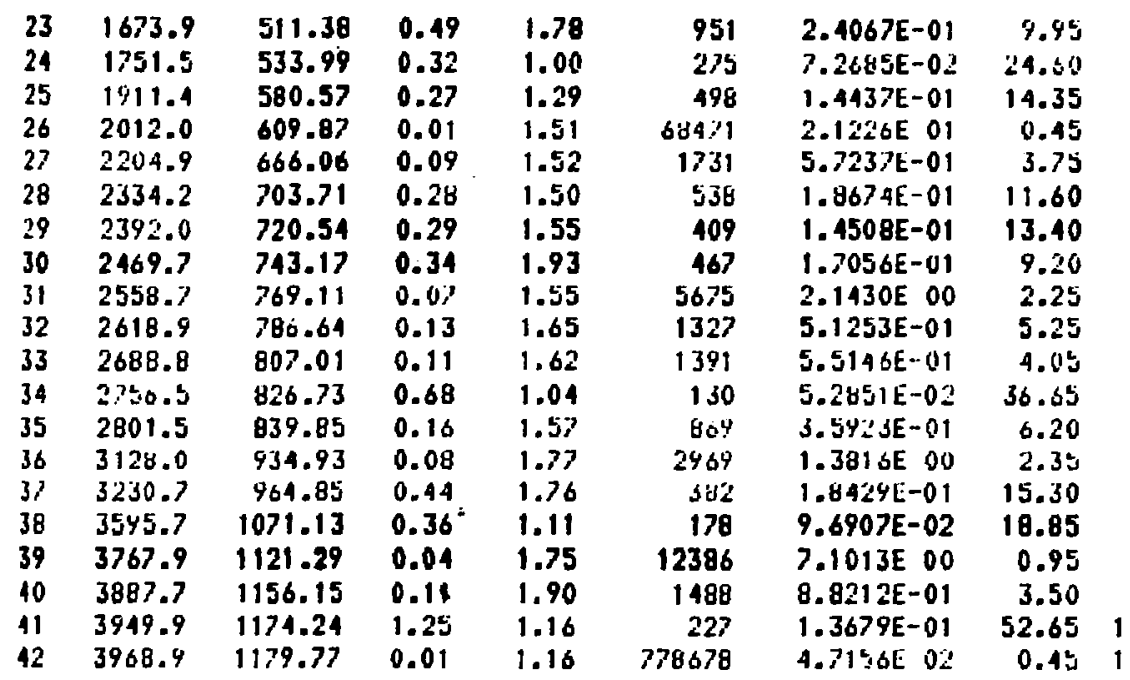

ISOIUH'L ANALISLS

UNITS : PCI/

CONUERSION FACTOR : $1.0000 \mathrm{~L} 0 \mathrm{~s}$

SI2E : $1.00 \mathrm{NOE}$ 00

PEAK AILALYSIS

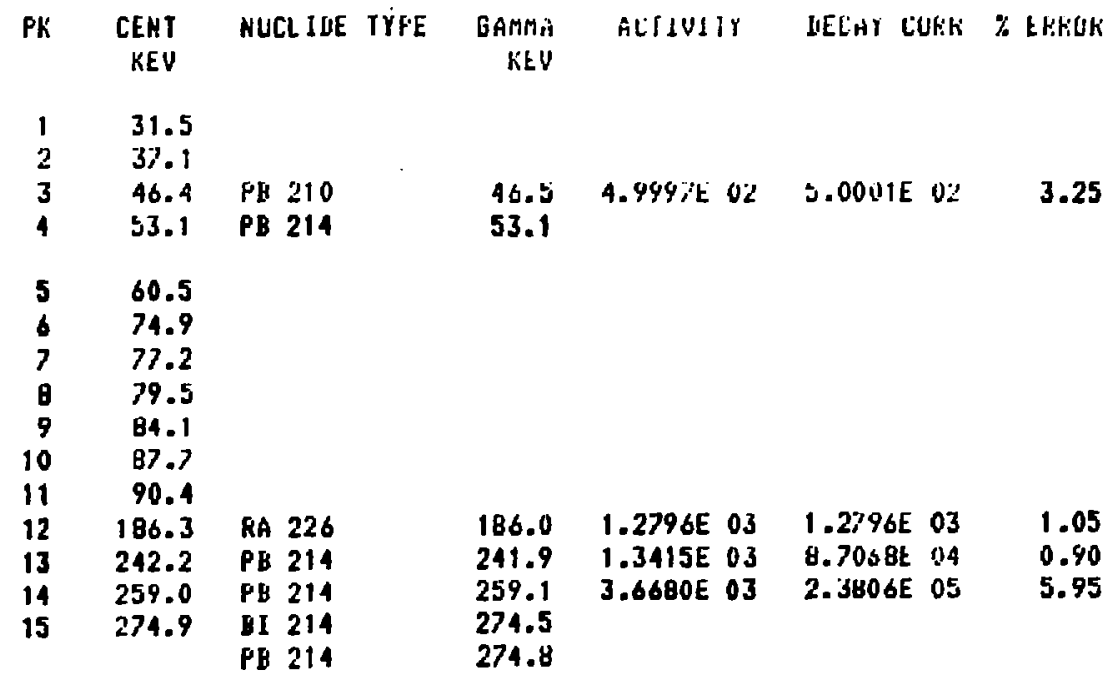


Table A.4. (cont'd)

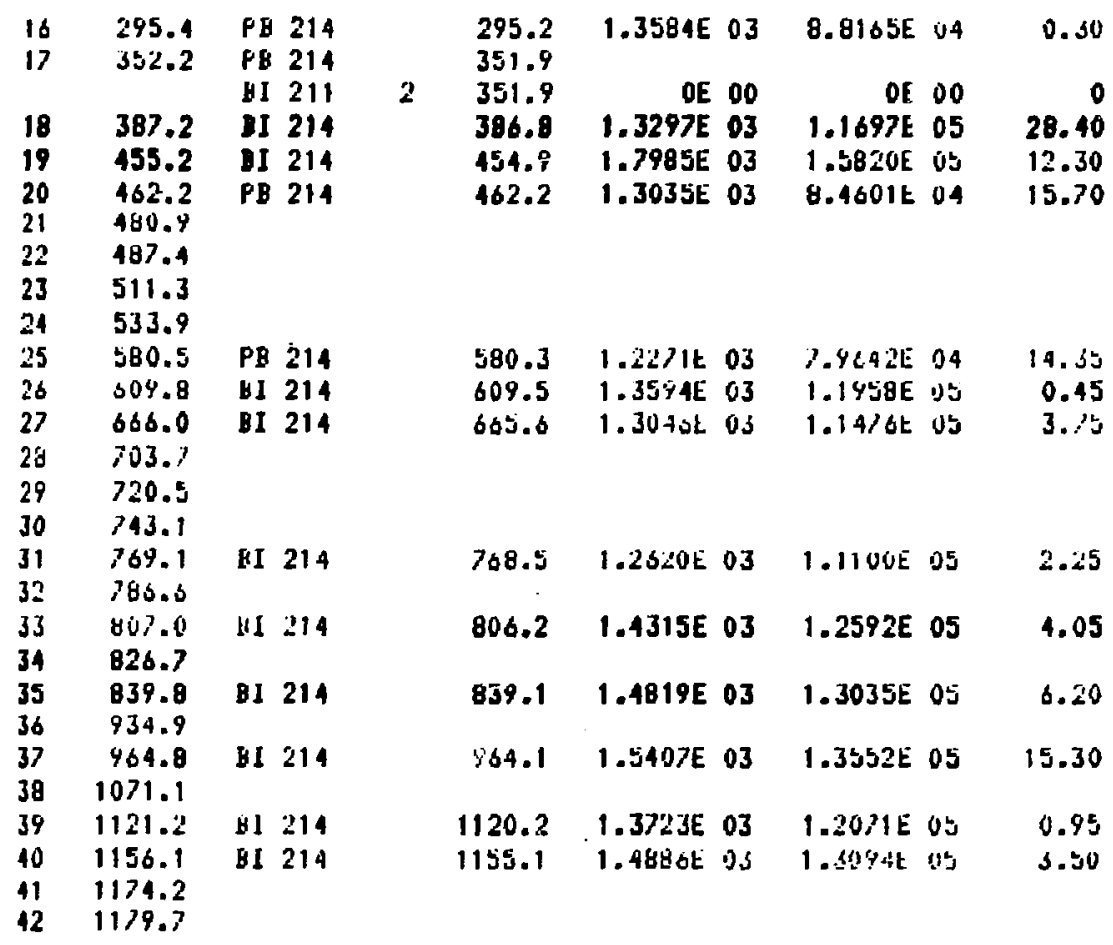


Table A.5. Mean Activities of Nuclides in Radium Standard B

MEAN AC IIVITIES

\begin{tabular}{|c|c|c|c|c|c|}
\hline J & 80 & ALIIVITY & X ERROR & \% CHISR & HALF LITIN] \\
\hline $\begin{array}{ll}\text { RA } & 226 \\
\text { H' } & 210 \\
\text { HI } & 211 \\
\text { H) } & 214 \\
\text { BI } & 214\end{array}$ & 2 & 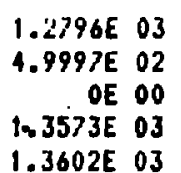 & $\begin{array}{r}3.25 \\
0 \\
0.28 \\
0.39\end{array}$ & $\begin{array}{r}0 \\
0 \\
0 \\
1.52 \\
0.54\end{array}$ & 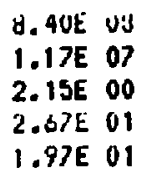 \\
\hline
\end{tabular}

Table A.6. Detection Limits of Nuclides in Radium Standard $B$

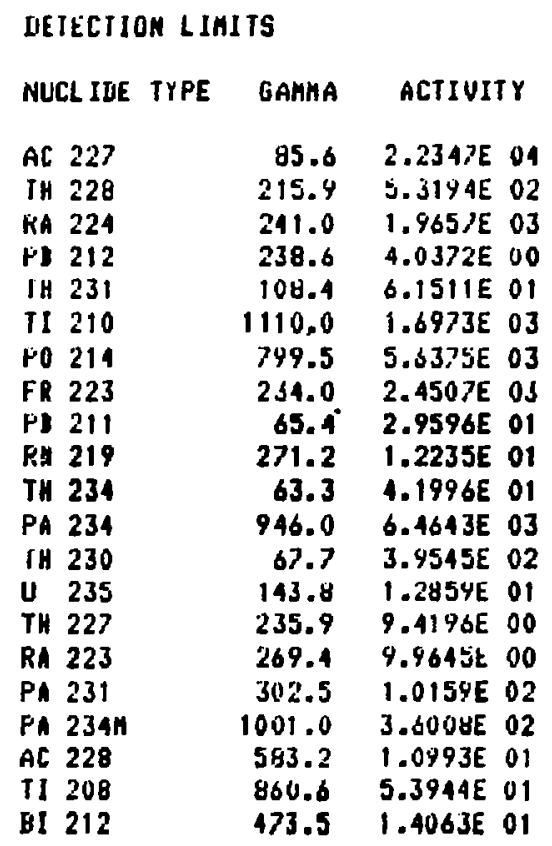


Table A.7. Gamma Spectrographic Analysis of the Pitchblende Ore Standard No. 6

ISO TOPE ANALYSIS

UNIIS : PCI/

CONUERSION FACTOR: $1.0000 E$ O6

S12E: $1.0000 E 00$

PEAK ANALYSIS

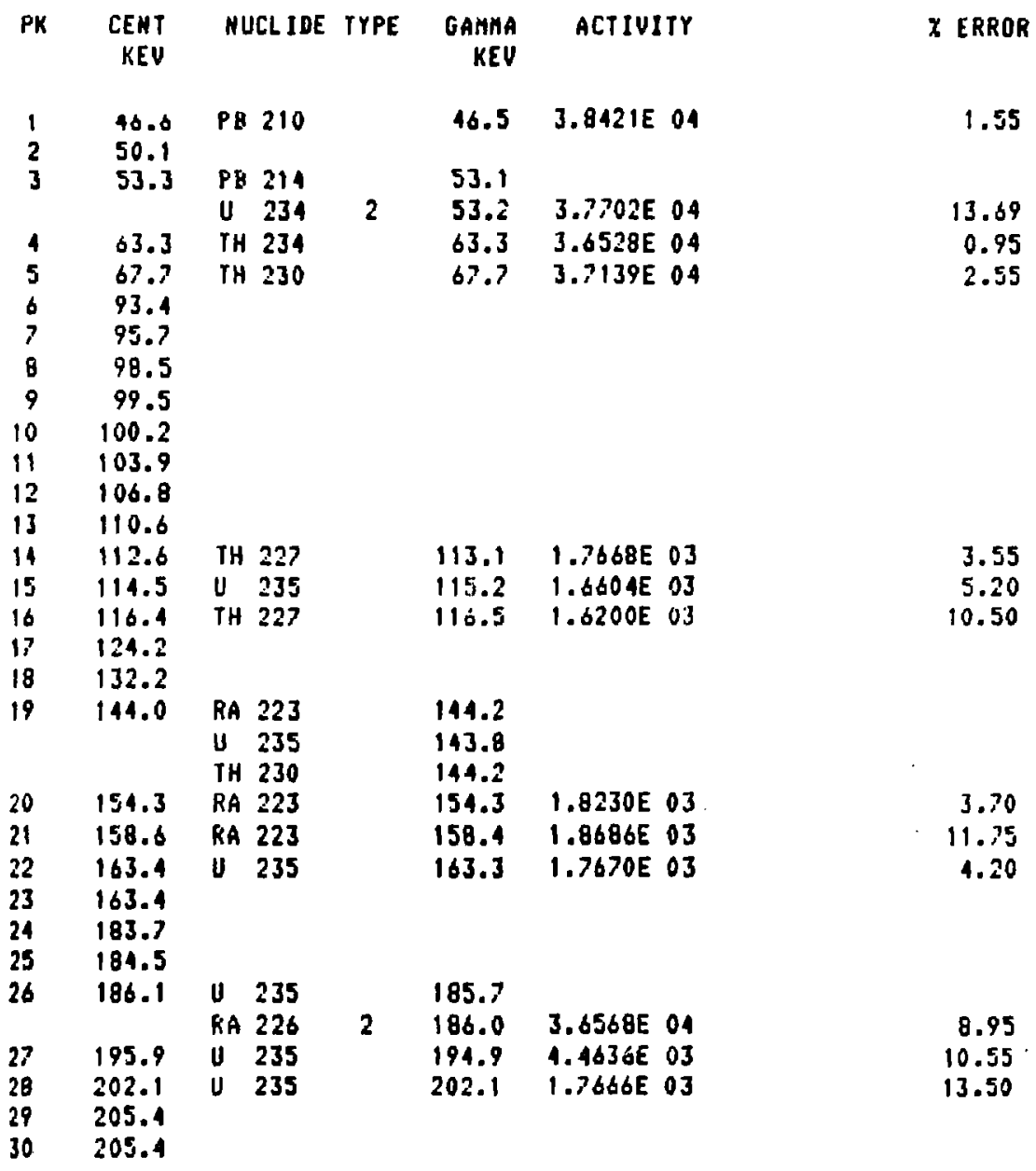


Table A.7. (cont'd)

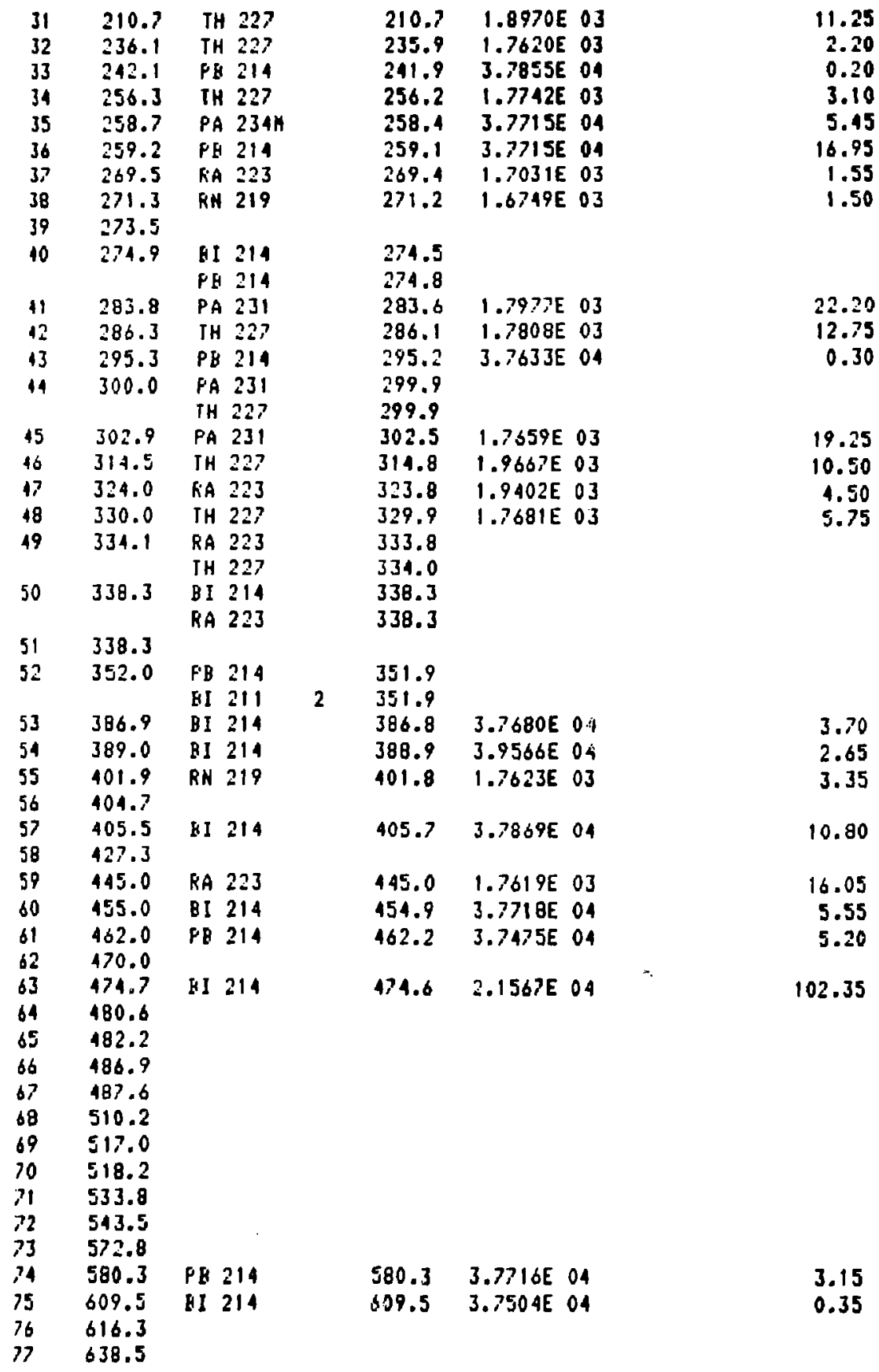


Table A.7. (cont'd)

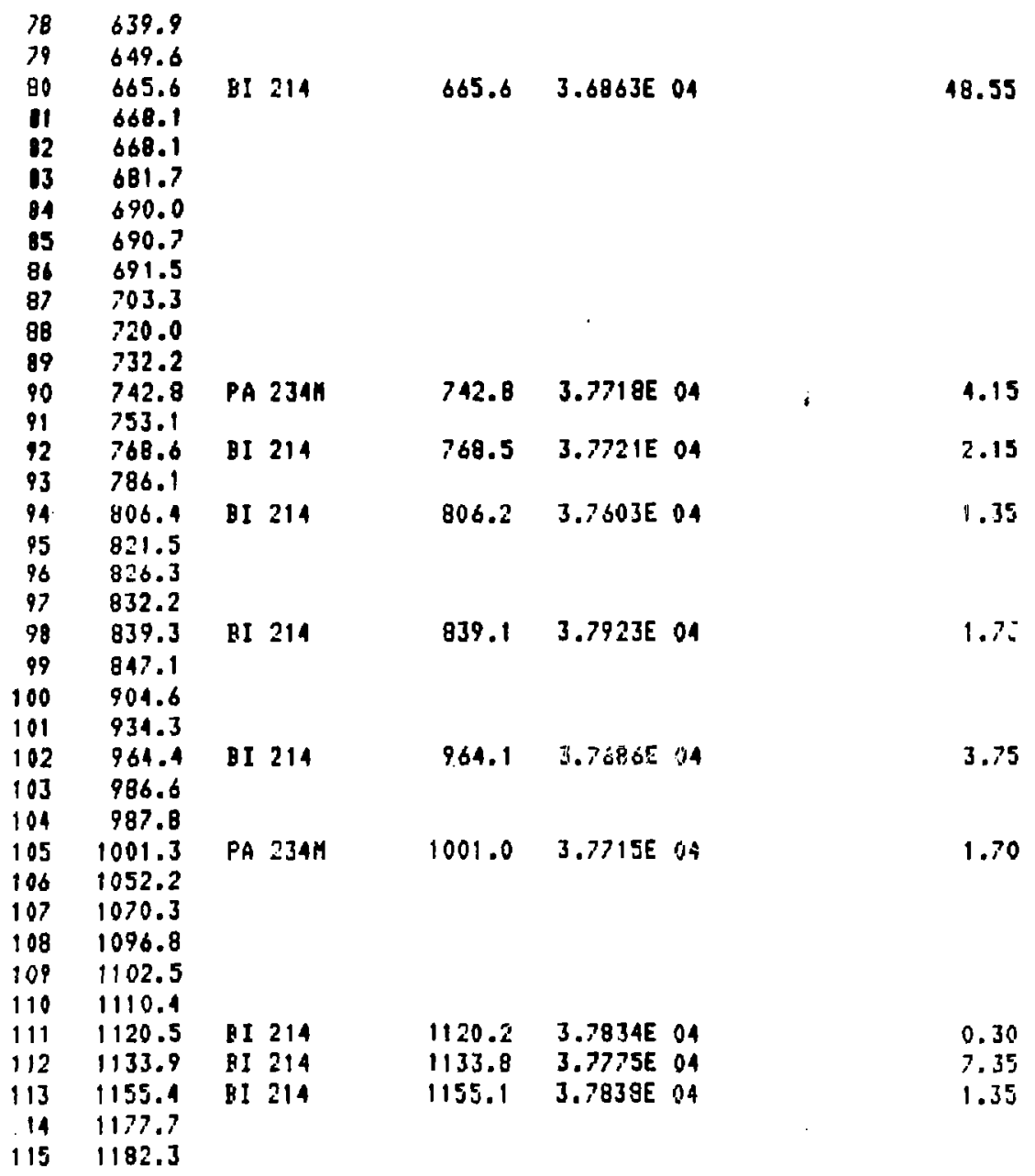


Table A.8. Mean Activities of Nuclides in Pitchblende Ore Standard No. 6

MEAN ACTIUITIES

NUCLIDE TYPE ACTIUITY \& ERROR 7 CHISQ

$\begin{array}{llrrrr}\text { U } 234 & 2 & 3.7702 E & 04 & 13.69 & 0 \\ \text { RA 226 } & 2 & 3.6568 E & 04 & 8.95 & 0 \\ \text { FI 210 } & & 3.8421 E & 04 & 1.55 & 0 \\ \text { RH 219 } & & 1.6893 E & 03 & 1.36 & 1.86 \\ \text { BI 211 } & & & & & \\ \text { TH 234 } & & 3.6528 E & 04 & 0.95 & 0 \\ \text { TH 230 } & & 3.7139 E & 04 & 2.55 & 0 \\ \text { FB 214 } & & 3.7785 E & 04 & 0.16 & 0.13 \\ \text { U 235 } & & 1.7606 E & 03 & 3.09 & 10.44 \\ \text { TH 227 } & & 1.7683 E & 03 & 1.48 & 0.81 \\ \text { RA 223 } & & 1.7370 E & 03 & 1.34 & 2.03 \\ \text { BI 214 } & & 3.7709 E & 04 & 0.21 & 0.16 \\ \text { FA 231 } & & 1.7793 E & 03 & 14.54 & 0.88 \\ \text { PA 234H } & & 3.7716 E & 04 & 1.51 & 0.00\end{array}$

Table A.9. Detection Limits of Nuclides in Pitchblende Ore Standard No. 6

IIETECIION LIHITS

\begin{tabular}{rrrrr} 
NUCL IDE TYPE & GAMHA & \multicolumn{2}{c}{ ACTIUITY } \\
& & & & \\
AC 227 & & 160.0 & $1.1408 E$ & 05 \\
TH 228 & & 217.0 & $3.3133 E$ & 03 \\
RA 224 & 240.9 & $7.2667 E$ & 04 \\
FI 212 & 238.6 & $2.5422 E$ & 01 \\
BI 212 & 1078.8 & $3.8601 E$ & 03 \\
TH 231 & 58.5 & $3.8462 E$ & 03 \\
TI 210 & 789.2 & $4.9170 E$ & 04 \\
PO 214 & 799.5 & $5.5953 E$ & 04 \\
FR 223 & 234.0 & $7.3529 E$ & 04 \\
F' 211 & 65.4 & $1.8301 E$ & 03 \\
PH 234 & 946.0 & $5.3990 E$ & 04
\end{tabular}


Table A.10. Gamma Spectrographic Analysis of Pitchblende Ore Standard No. 100

SAHPLE DRE SILL.DECEHBER A.1980

COUNT TIME (SEL): $3.30000 E$ O5

EHERGY CALIBRATIOH

ID: NOU. $17 / 80$ OFF $=80$ GAIN=100/F6

ISOTOPE ANALYSIS

UNITS : PCI/

CONUERSION FACTOR : $1.0000 E$ OS

SIZE : $1.0000 E 00$

PEAK allaLYSIS

PK CENT HUCLIDE TYPE GAMHA ACTIUITY \% ERROR KEV KEV

$\begin{array}{ll}1 & 46.5 \\ 2 & 49.9 \\ 3 & 53.1\end{array}$

PB 210

46.5

$5.9284 E 03$

1.10

PB 214

บ 234

63.1 TH 234

5

$8 \quad 67.6$

TH 230

ป. 235

114.4

123.7

130.6

KN. 219

U. 235

RA 223

i 235

TH 230

$12 \quad 154.1$

BI 212

RA 223

$\begin{array}{llll}13 & 163.3 & \mathrm{U} & 235\end{array}$

$14 \quad 165.5$ .

$15 \quad 185.9$

U. 235

RA 226

$\begin{array}{llll}16 & 195.8 & U^{\prime} 235\end{array}$

$17 \quad 205: 2$

$18 \quad 210.4$

TH̉ 227

235.9 TH 227

ข. 235

PB 214

RA 224

$21 \quad 256.1$ TH 227

53.1

2

53.

9.8365503

14.73

$63.3 \quad 5.4280 \mathrm{E} \quad 3 \quad 1.30$

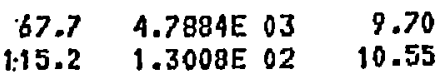

$130.8 \quad 4.5691 E \quad 02 \quad 14.90$

$940.8 \quad 1.8730 \mathrm{E} 03 \quad 12.90$

144.2

143.48

144.2

$2 \quad 154.0$

154.3

163.3

$1.8976 E \quad 02$

43.43

$3.7853 E 02 \quad 7.60$

185.7

$\begin{array}{llll}186.0 & 6.0530 \mathrm{E} & 03 & 2.59\end{array}$

$194.9 \quad 6.8355502 \quad 15.35$

$\begin{array}{lllll}210.7 & 2.3990 E & 02 & 14.70\end{array}$

$235.9 \quad 2.2467 E$ 02 2.15

$20 \quad 241.9$ 240.9

241.9

2241.0

4.9465E 01 256:2 2.3784E O2 
Table A.10. (cont'd)

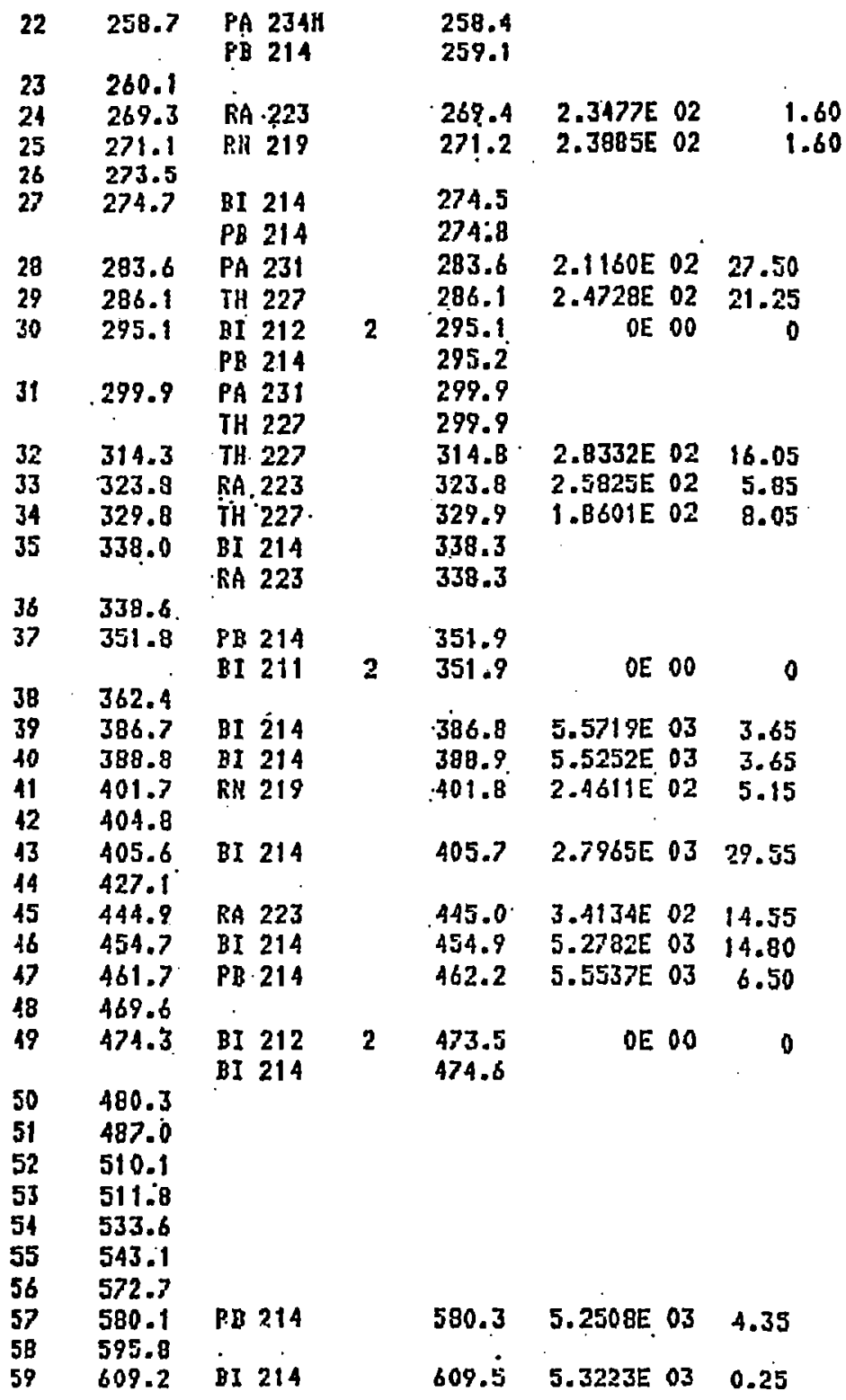


Table A.10. (cont'd)

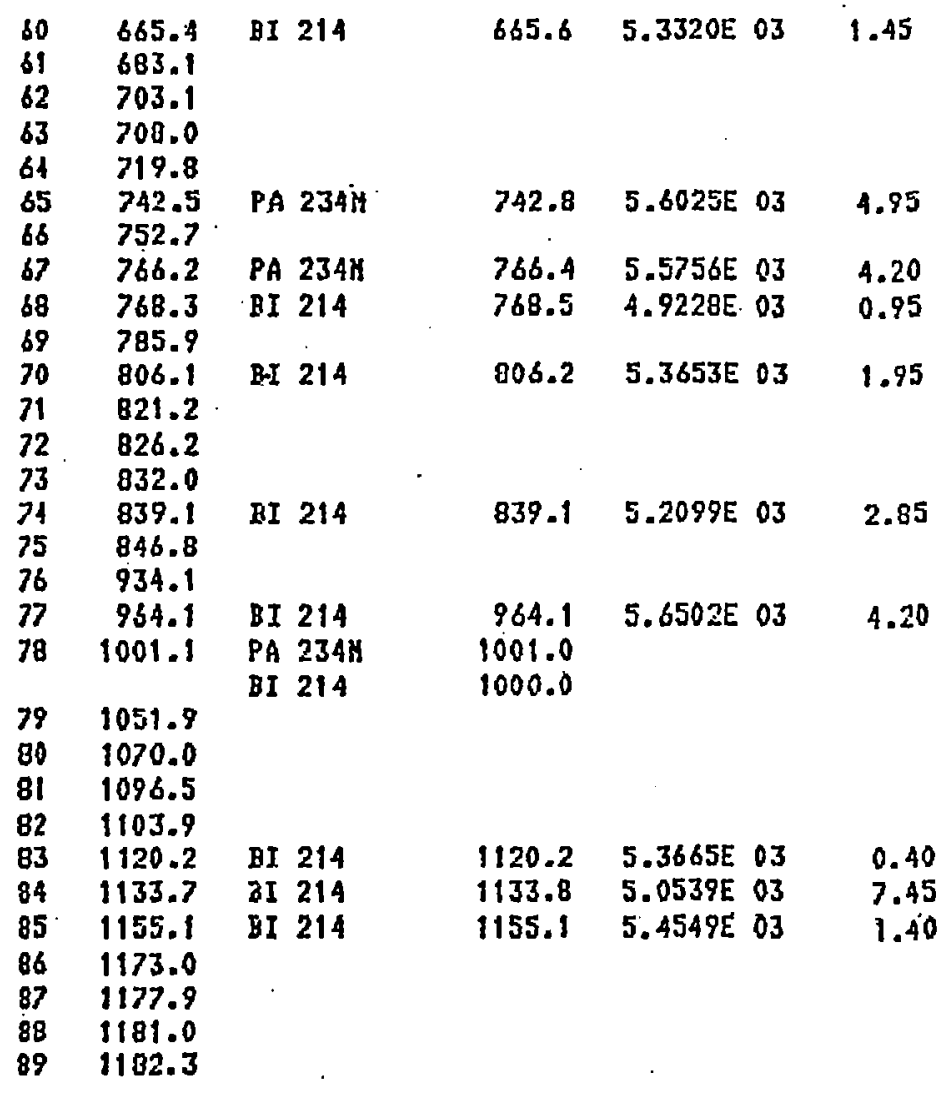


Table A.11. Mean Activities of Nuclides in Pitchblende Ore Standard No. 100

MEAN ACTIYITIES

NUCLIDE TYPE ACTIUITY $Z$ ERFOR $Z$ CHISQ

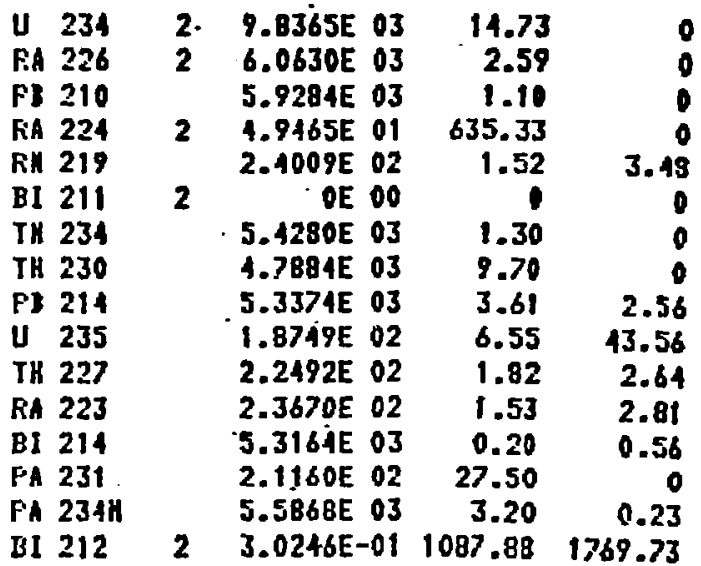

Table A.12. Detection Limfts of Nuclides in Pitchblende Ore Standard No. 100

IETECTIOH LICHTS

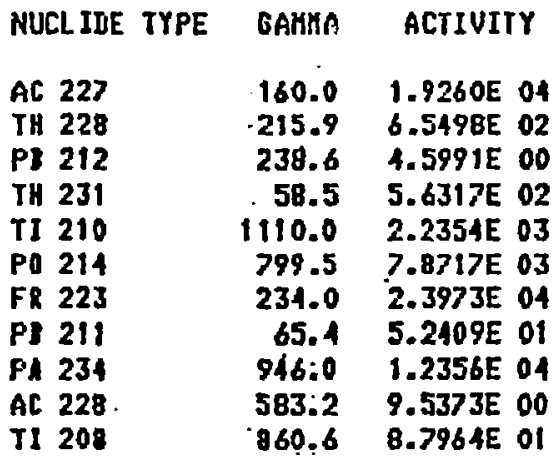


REFERENCES FOR APPENDIX A

1. Percival, D.R. and Martin, D.B. 1974. "Sequential Determination of Radium-226, Radium-228, Actinium-227, and Thorium Isotopes in Environmental and Process Waste Samples," Anal. Chem. 46:1742.

2. Sill, C.W. and Willis, C.P. 1965. "Radiochemical Determination of Lead-210 in Mill Products and Biological Materials," Anal. Chem. 37:1661.

3. Sill, C.W. and Williams, R.L. 1969. "Radiochemical Determination of Uranium and the Transuranium Elements in Process Solutions and Environmental Samples," Anal. Chen. 41:1624.

4. Sill, C.W. and Hindman, F.D. 1974. "Simultaneous Determination of Alpha-Emitting Nuclides of Radium through Californium in Soil," Anal. Chem. 46:1725.

5. Sill, C.W. 1976. "Determination of Thorium and Uranium Isotopes in Ores and Mill Tailings by Alpha Spectrometry," Health Services Laboratory, U.S. Energy Research and Developwent Administration, Idaho Falls, Idaho.

6. Sill, C.W. 1977. "Simultaneous Determination of ${ }^{238} \mathrm{U},{ }^{234} \mathrm{U},{ }^{230} \mathrm{Th}$, ${ }^{226} \mathrm{Ra}$, and ${ }^{210} \mathrm{~Pb}$ in Uranium Ores, Dusts, and Mill Tailings," Workshop on Methods for Measuring Radiation in and around Uranium Mills, Prograa Report 3(9), Atomic Industrial Forum, Inc. Washington, D.C. 
APPENDIX B. POLYNOMIAL COEFFICIENTS FOR THE EFFICIENCY FUNCTION AND STATISTICS OF LEAST-SQUARES FIT OF DATA

\section{REGION 1 (40-145 keV)}

Number of iterations $=1$

Standard deviation of point of unit weight $=0.00257348440848$

R-square (goodness-of-fit statistic) $=0.974415106629$

$\underline{\mathbf{i}}$

Parameter $\mathrm{A}_{\mathbf{i}}$

Std. Dev. $A_{i}$

$1-0.0627222839251$

0.02144994537

2

0.00425700978636

7.399956887E-4

3

$-3.104655584 \mathrm{E}-5$

7.823006845E-6

4

$6.447985728 \mathrm{E}-8$

$2.595272286 \mathrm{E}-8$

REGION $2(145-610 \mathrm{keV})$

Number of iterations $=1$

Standard deviation of point of unit weight $=0.00124982157664$

R-square (goodness-of-fit statistic) $=0.996085202934$

\begin{tabular}{lll}
$\frac{i}{i}$ & \multicolumn{1}{c}{ Parameter $\mathrm{A}_{\mathrm{i}}$} & \multicolumn{1}{c}{ Std. Dev. $\mathrm{A}_{\mathrm{i}}$} \\
\cline { 2 - 3 } 2 & 0.16187659187 & 0.00482823092357 \\
3 & $-6.496720091 \mathrm{E}-4$ & $4.454643661 \mathrm{E}-5$ \\
4 & $1.085893015 \mathrm{E}-6$ & $1.272990093 \mathrm{E}-7$ \\
& $-6.526909298 \mathrm{E}-10$ & $1.135229486 \mathrm{E}-10$
\end{tabular}

REGION $3(610-1400 \mathrm{keV})$

Number of iterations $=1$

Standard deviation of point of unit weight $=5.921878727 \mathrm{E}-4$

R-square (goodness-of-fit statistic) $=0.96544587054$

\begin{tabular}{lcc}
$i$ & Parameter A $_{i}$ & $\frac{1}{\text { Std. Dev. } A_{i}}$ \\
\cline { 2 - 3 } 2 & 0.107576619786 & 0.0190544950311 \\
3 & $-2.40695096 \mathrm{E}-4$ & $5.700447101 \mathrm{E}-5$ \\
4 & $2.079626197 \mathrm{E}-7$ & $5.561226132 \mathrm{E}-8$ \\
\hline
\end{tabular}




\section{ACKNOWLEDGHENTS}

I would like to thank Drs. Lyle Roberts and Albert Gudat for their reviews of the draft of this report and their constructive suggestions. I am grateful to D. Rayno for his assistance in preparation of samples and measurement of activity in selected samples using an alpha spectroscopy technique. I am indebted to Claude $W$. Sill for providing the uranium ore samples. I acknowledge the support of both Leonard Link and Walt Kisieleski during these studies. I would also like to thank Beatrice Grabowski for her meicculous editorial reviews of the manuscript and John DePue for the final preparation of the manuscript.

I am indebted to Dr. Dennis Melodowitch, Application Programming, for preparation of software and to staff of Northland Corporation for technical assistance during these studies. 


\section{Distribution of ANL/ES-118}

Interna 1 :
E.S. Beckjord
L. Burris
P.G. Chee
P.T. Cunninghan
C.A. DeLorenzo
A.J. Dvorak
P.R. Fields
B.R.T. Frost
A.E. Gudat
W.J. Hallett
E. Huberman
W.E. Kisieleski
J.H. Kittel
L.G. LeSage
J.H. Martens
M.H. Homeni (50)
D. Rayno
C.J. Roberts
R.E. Rowland
J. Rundo
J.P. Schiffer
J. Sedlet
A.F. Stehuey
M.G. Strauss
R.J. Teunis
C.E. Till
Y. Yuan
ANL Patent Department
ANL Contract File
ANL Libraries (2)
TIS Files (6)

\section{Externa 1:}

DOE, for distribution per UC-11 (236)

Manager, Chicago Operations of fice, DOE

President, Argonne Universities Association

Division of Environmental Impact Studies Review Comittee:

S. Burstein, Wisconsin Electric Power Co.

J.W. Firor, National Center for Atmospheric Research

B.M. Hannon, University of Illinois, Urbana

D.W. Moeller, Harvard University

H.G. Morgan, Carnegie-Mellon University

A.F. Smith, University of Michigan

B.G. Wixson, University of Missouri-Rolla

G.F. Knoll, University of Michigan,

D. Melodowitch, Northland Corp., Fort Atkinson, WI

M. Merritt, Sandia National Laboratory, Albuquerque

G.E. Miller, University of California, Irvine

A. Moghissi, U.S. Environmental Protection Agency, Washington

M.E. Nelson, United States Geological Survey, Albuquerque

R.W. Perkins, Pacific Northwest Laboratory

H. Rarrich, Sandia National Laboratory, Albuquerque

C.W. Sill, EG\&G, Idaho

A.R. Smith, Lawrence Berkeley National Laboratory

J. Van Allen, University of Iowa

R. Vaninbroukx, Centraal Bureau voor Nuclearie Metingen van de Europese Gemeenschappen, Geel, Belgium

M.G. White, Office of Nuclear Waste Management, USDOE

J. Youngerman, University of California, Davis 